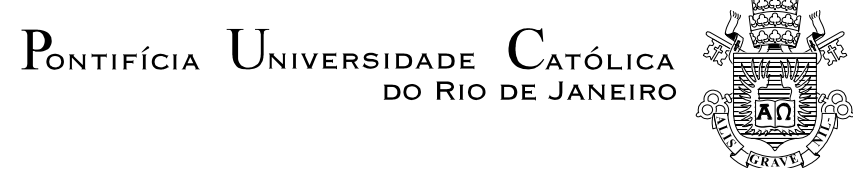

Tatiana Cavalcanti Marques

\begin{abstract}
A Rede de Atenção Psicossocial (RAPS) no atendimento às mulheres puérperas usuárias de drogas na perspectiva da convivência familiar
\end{abstract}

Dissertação de Mestrado

Dissertação apresentada ao Programa de Pósgraduação em Serviço Social da PUC-Rio como requisito parcial para obtenção do título de Mestre em Serviço Social

Orientador: Profa. Irene Rizzini

Rio de Janeiro Setembro de 2015 


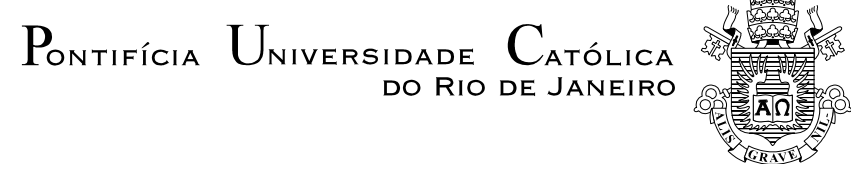

Tatiana Cavalcanti Marques

\title{
A Rede de Atenção Psicossocial (RAPS) no atendimento às mulheres puérperas usuárias de drogas na perspectiva da convivência familiar
}

Dissertação apresentada como requisito parcial para obtenção do grau de Mestre pelo Programa de PósGraduação em Serviço Social da PUC-Rio. Aprovada pela Comissão Examinadora abaixo assinada.

\author{
Profa. Irene Rizzini \\ Orientador \\ Departamento de Serviço Social - PUC-Rio
}

Prof. Antonio Carlos de Oliveira Departamento de Serviço Social - PUC-Rio

Profa. Rosana Morgado

UFRJ

Profa. Mônica Herz

Vice-Decana de Pós-Graduação do Centro de Ciências Sociais - PUC-Rio 
Todos os direitos reservados. É proibida a reprodução total ou parcial do trabalho sem a autorização da universidade, do autor e do orientador.

\section{Tatiana Cavalcanti Marques}

Graduou-se em Serviço Social pela Universidade Federal Fluminense (UFF) em 2007, possui especialização em Psicologia Jurídica pelo Instituto A Vez do Mestre da Universidade Cândido Mendes (UCAM) em 2009 e graduouse em Direito pela Universidade Federal do Rio de Janeiro (UFRJ) em 2012. Atualmente é assistente social do Hospital Universitário Gaffrée e Guinle da Universidade Federal do Estado do Rio de Janeiro - UNIRIO.

Ficha Catalográfica

Marques, Tatiana Cavalcanti

A Rede de Atenção Psicossocial (RAPS) no atendimento às mulheres puérperas usuárias de drogas na perspectiva da convivência familiar / Tatiana Cavalcanti Marques; orientadora: Irene Rizzini. - 2015.

$95 \mathrm{f} . ; 30 \mathrm{~cm}$

Dissertação (mestrado) - Pontifícia Universidade Católica do Rio de Janeiro, Departamento de Serviço Social, 2015.

Inclui bibliografia.

1. Serviço social - Teses. 2. Convivência familiar. 3. Políticas públicas. 4. Puérperas. 5. Usuárias de drogas. 6. Rede de Atenção Psicossocial. I. Rizzini, Irene. II. Pontifícia Universidade Católica do Rio de Janeiro. Departamento de Serviço Social. III. Título. 


\section{Agradecimentos}

A Deus, aos meus pais Sônia e José Luís, à minha irmã Thaís (companheira e essencial), ao meu esposo Eduardo pelo carinho e conselhos, ajudando a superar os desafios.

Aos familiares e amigos de trabalho e mestrado, em especial Edna, pelo imenso apoio nas leituras da dissertação e Deise, pela motivação.

À Irene Rizzini, pelos ensinamentos e orientações fundamentais para a realização do presente estudo. Aos professores Antônio Carlos de Oliveira e Rosana Morgado pelas valiosas contribuições no exame de qualificação. Ao corpo docente do Programa de Pós-Graduação em Serviço Social da PUC-Rio pela confiança e respeito e à Joana por sua atenciosidade. 


\section{Resumo}

Marques, Tatiana Cavalcanti; Rizzini, Irene. A Rede de Atenção Psicossocial (RAPS) no atendimento às mulheres puérperas usuárias de drogas na perspectiva da convivência familiar. Rio de Janeiro, 2015. 95 p. Dissertação de Mestrado - Departamento de Serviço Social, Pontifícia Universidade Católica do Rio de Janeiro.

A pesquisa tem como objetivo analisar a Rede de Atenção Psicossocial (RAPS) para o atendimento às mulheres usuárias de drogas da maternidade de um hospital universitário na cidade do Rio de Janeiro. Como pontos específicos do estudo, discutiu-se a política de drogas vigente no município, além do mapeamento dos equipamentos disponíveis, no âmbito da saúde, na rede no território do hospital buscando contribuir para subsidiar políticas e serviços voltados para esse grupo na perspectiva da convivência familiar. Realizou-se uma pesquisa exploratória sobre esse tema bastante atual, porém, ainda pouco estudado. Como recursos metodológicos, foi realizada uma análise crítica da literatura acadêmica, das legislações e das políticas a respeito do assunto, além da participação em oficinas de debates e seminários, o que muito contribuiu para as reflexões. O estudo permitiu constatar que a rede ainda não possui serviços específicos voltados para o atendimento às puérperas usuárias de drogas, os dispositivos atuam de forma isolada e incipiente com equipamentos precarizados e contam com a presença de um número reduzido de profissionais.

\section{Palavras-chave}

Convivência Familiar; Políticas Públicas; Puérperas; Usuárias de Drogas; Rede de Atenção Psicossocial. 


\section{Abstract}

Marques, Tatiana Cavalcanti; Rizzini, Irene (Advisor). The Psychosocial Care Network for pregnant women who are drug users in the context of family life. Rio de Janeiro, 2015. 95 p. Msc. Dissertation - Departamento de Serviço Social, Pontifícia Universidade Católica do Rio de Janeiro.

The research aims to Analyze the Psychosocial Care Network that serve pregnant women who are drug users at a university hospital in the city of Rio de Janeiro. Some specific issues were discussed, such as: the current drug policy in the city and the mapping of services available within the health care network in the hospital territory aiming at contributing to support policies and services for this group in view of family life. An exploratory study was carried out focusing on this very current topic, though still under explored. As methodological resources, a critical analysis of academic literature, legislation and policy on the matter was carried out, as well as participation of the researcher in workshops debates and seminars, which greatly contributed to the current analysis. Results pointed out that the network does not have any specific service for mothers who are drug users, services operate in isolated and precarious ways and rely on a small number of professionals.

\section{Keywords}

Family Life; Public Policy; Pregnant Women; Drug Users; Psychosocial Care Network. 


\section{Sumário}

Introdução

1. Família (s) e políticas sociais: de quem é a responsabilidade?

1.1. Análise sobre as influências das transformações societárias nas famílias

1.2. As políticas sociais no contexto neoliberal e seus impactos na família

2. A trajetória da saúde mental na sociedade brasileira e o "tratamento" oferecido aos usuários de drogas na cidade do Rio de Janeiro

2.1. Aspectos normativos e históricos sobre a saúde mental no Brasil com enfoque na drogadição

2.2. A política de drogas na cidade do Rio de Janeiro tratamento ou punição?

3. A Rede de Atenção Psicossocial (RAPS) no trabalho desenvolvido com as puérperas usuárias de drogas da maternidade de um hospital universitário na perspectiva da convivência familiar

3.1. A intersetorialidade e a interdisciplinaridade na Rede de Atenção Psicossocial (RAPS) e a precarização enfrentada pelos trabalhadores da rede

3.2. A identificação dos serviços da Rede de atenção psicossocial (RAPS) no território de um hospital universitário e a sua contribuição no atendimento às puérperas com "uso problemático de drogas" na perspectiva da convivência familiar

4. Considerações Finais

5. Referências Bibliográficas 


\section{Lista de quadros e mapas}

Quadro 1 Componentes da Rede de Atenção 69 Psicossocial

Mapa 1 Áreas Programáticas do município do Rio de 74 Janeiro

Quadro 2 Identificação da Rede de Atenção Psicossocial da Área Programática 2.2 para o suporte do trabalho desenvolvido na maternidade do hospital universitário 


\section{Lista de siglas e abreviaturas}

AP - Área Programática

CAPS - Centro de Atenção Psicossocial

CAPS AD - Centro de Atenção Psicossocial de Álcool e Drogas

CAPSI - Centro de Atenção Psicossocial Infantil

CEBES - Centro Brasileiro de Estudos de Saúde

CEBRID/UNIFESP - Centro Brasileiro de Informações Sobre Drogas

Psicotrópicas da Universidade Federal de São Paulo

CEDECA - Centro de Defesa dos Direitos da Criança e do Adolescente

CID - Classificação Internacional das Doenças

CMS - Centro Municipal de Saúde

COFEN - Conselho Federal de Entorpecentes

CONAD - Conselho Nacional de Política sobre Drogas

CRESS RJ - Conselho Regional de Serviço Social do Rio de Janeiro

CRFB/88 - Constituição da República Federativa do Brasil de 1988

CRP RJ - Conselho Regional de Psicologia do Rio de Janeiro

ECA - Estatuto da Criança e do Adolescente

ENSP - Escola Nacional de Saúde Pública

FEDDH-RJ - Frente Estadual Drogas e Direitos Humanos do Rio de Janeiro

FIOCRUZ - Fundação Oswaldo Cruz

FNDDH - Frente Nacional Drogas e Direitos Humanos

HU - Hospital Universitário

IPEA - Instituto de Pesquisa Econômica Aplicada

MPRJ - Ministério Público do Estado do Rio de Janeiro

MTSM - Movimento dos Trabalhadores em Saúde Mental

NOB/SUAS - Norma Operacional Básica do Sistema Único de Assistência

Social

OMS - Organização Mundial da Saúde

ONU - Organização das Nações Unidas

OPAS - Organização Panamericana de Saúde 
PNAD - Política Nacional sobre Drogas

PNAS - Política Nacional de Assistência Social

PT - Partido dos Trabalhadores

RAPS - Rede de Atenção Psicossocial

SAF - Síndrome Alcóolica Fetal

SAMU - Serviço de Atendimento Móvel

SENAD - Secretaria Nacional de Políticas sobre Drogas

SISNAD - Sistema Nacional de Políticas Públicas sobre Drogas

SMAS - Secretaria Municipal de Assistência Social

SUPERA - Sistema para deteç̧ão do uso abusivo e dependência de substâncias psicoativas: encaminhamento, intervenção breve, reinserção social e acompanhamento

SUS - Sistema Único de Saúde

UERJ - Universidade do Estado do Rio de Janeiro 


\section{Introdução}

Nos últimos anos, os profissionais do hospital universitário do estudo em questão têm se deparado com uma nova demanda que é a internação de gestantes usuárias de drogas. Na maioria dos casos, essas gestantes não realizam pré-natal, encontram-se com os vínculos familiares fragilizados ou rompidos, sem documentação civil e que, em muitas das vezes, possuem como a única porta de acesso ao serviço de saúde o hospital, na hora do parto. Embora não sejam muitas as ocorrências de uso de drogas na maternidade, em cada caso específico há pelo menos duas vidas envolvidas nesse processo. $\mathrm{E}$, geralmente, o que acontece é uma atuação voltada para uma preocupação restrita à proteção das crianças em detrimento da mãe. Observa-se que, com frequência, as mães são criminalizadas e separadas dos seus filhos, em alguns casos, retornando para as ruas, para as drogas e para uma possível nova gravidez não planejada. Acreditamos que não se possa pensar no direito de ambos de forma concorrente, mas sim coexistente.

Para todos os casos que surgem com a problemática em questão no hospital universitário, a equipe da maternidade aciona imediatamente o Serviço Social. Assim, no primeiro momento, o assistente social vai à enfermaria e dialoga com os demais profissionais e a puérpera. Meu primeiro contato com um caso deste ocorreu no ano de 2013. No atendimento à paciente, ao mesmo tempo em que avistei uma mulher com aspecto sofrido e maltratado, a qual necessitava de apoio, visualizei um recém-nascido indefeso. Era uma mãe sozinha em um leito que tinha a sua privacidade figurada por uma cortina de pano e um bebê num berçário com toda uma equipe o acompanhando em virtude do uso de drogas durante a gestação. Os rostos de alguns profissionais ali envolvidos estampavam olhares de cuidado, mas também de preconceito, o qual é intensificado constantemente por valores conservadores. Essa situação trouxe a vontade de realizar um estudo com essas puérperas usuárias de drogas.

Algumas perguntas foram importantes para o desenvolvimento deste estudo, como: o que fazer para atender às necessidades dessas mulheres que sofrem uma constante violação de direitos? Por que os direitos assegurados nas leis não são efetivados pelas políticas públicas e práticas vigentes? E o direito 
dessas mães de permanecerem com os seus filhos? E o direito dessas mães de entregarem seus filhos para a adoção? Será que o suporte familiar auxiliaria no tratamento das drogas? O uso da rede de atenção psicossocial evitaria a institucionalização de crianças e o retorno das mulheres para o uso abusivo de drogas e a vida nas ruas? Essas inquietações foram os grandes motivadores do presente estudo, além da minha experiência profissional como assistente social em um hospital universitário e por já ter atuado em um Centro de Atenção Psicossocial em Álcool e Drogas (CAPS AD) de um município da Baixada do Rio de Janeiro.

A presente pesquisa tem como objetivo principal analisar a Rede de Atenção Psicossocial (RAPS) no atendimento às puérperas usuárias de drogas na maternidade do hospital universitário em questão na perspectiva da convivência familiar. Neste universo, como objetivos específicos foram propostos os seguintes tópicos: 1) discutir a política de drogas vigente no município do Rio de Janeiro; 2) mapear os equipamentos disponíveis na rede de atenção psicossocial no território do hospital universitário; e 3) fornecer subsídios para as políticas e serviços voltados para o segmento em estudo na perspectiva da convivência familiar.

A dissertação é composta por três capítulos. O primeiro apresenta uma reflexão sobre a família de maneira histórica e conceitual, discutindo as mudanças ocorridas nas organizações familiares. Em função da complexidade do fenômeno em questão, optou-se por iniciar com uma revisão crítica da literatura sobre a família a partir das suas novas configurações oriundas do processo de transformações societárias.

A família é a primeira referência do ser humano, sendo a principal responsável por sua formação, porém não a única, já que a todo momento o indivíduo sofre influências culturais, econômicas, políticas, entre outras. Assim, percebe-se que não é possível compreender a noção de família como um modelo cristalizado - único -; ao contrário, ela deve ser pensada em um processo de constante mudança que interfere diretamente no seu meio.

Ainda no primeiro capítulo, discutem-se os elementos teóricos sobre a relação entre as políticas públicas do Estado neoliberal e os seus impactos na família. Como será abordado ao longo do trabalho, segundo Behring e Boschetti (2008), o neoliberalismo preconiza a lógica de um Estado Mínimo, ou seja, há 
uma restrição e transferência das ações estatais para a sociedade, sobretudo para as famílias.

Diante disso, coloca-se em debate a ideia da centralidade na família, sendo esta a principal responsável pela resolução dos problemas existentes, sem levar em consideração as múltiplas expressões da questão social. Ainda, a família é culpabilizada quando não consegue "dar conta" do cuidado ${ }^{1}$ e proteção dos seus membros. Como apontam os autores Rizzini, Rizzini, Naiff e Baptista, "há um grande descompasso no Brasil entre a importância atribuída ao papel da família no discurso e a falta de condições mínimas de vida digna que as famílias enfrentam, na prática, para que possam criar seus filhos" (2006, p. 32).

No âmbito da supervalorização da família, um outro aspecto que se destaca é a questão de gênero, visto que é a mulher quem recebe praticamente toda a sobrecarga da provisão do bem-estar dos seus componentes em virtude de traços culturais de embasamento patriarcal, ou seja, o que há são "novas famílias" (diferentes arranjos familiares) e "velhas funções" (mulher cuidadora e homem provedor).

No segundo capítulo, tendo como foco do estudo as mulheres puérperas que fazem uso abusivo de drogas, aspectos normativos e históricos sobre a saúde mental no Brasil serão discutidos com base em pesquisa bibliográfica, por serem considerados de grande valia para a apreciação da rede de serviços. Além disso, será feita uma análise das concepções acerca da política de drogas vigente no município do Rio de Janeiro, a qual, em conjunto com o discurso midiático, lastreava-se em ações de recolhimento/acolhimento compulsório dos usuários em situação de rua, que são os mais expostos ao uso (Lima, 2010).

No terceiro capítulo, serão realizadas considerações sobre a escassez e a fragmentação de políticas públicas que acarretam no constante acionamento do Judiciário pela busca de resoluções para os conflitos existentes no cotidiano. Para evitar que esse processo seja o único caminho no atendimento às mulheres em estudo e considerando que a questão das drogas transcende o âmbito estritamente clínico, realizou-se um mapeamento da Rede de Atenção

\footnotetext{
${ }^{1}$ A noção de cuidado utilizada será a de Duarte, o qual apresenta que essa categoria "implica em cuidar do outro em toda a sua dimensão humana, subjetiva e objetiva, no campo do pensamento, da emoção e da ação" (2013, p. 77).
} 
Psicossocial, instituída pela portaria № 3.088 de 23/12/11, da área programática 2.2, território ${ }^{2}$ de saúde onde se localiza o hospital universitário.

A temática do estudo é relevante por se tratar de um assunto que perpassa diversas áreas, principalmente a saúde e a assistência social. Acrescenta-se que não há a pretensão de esgotar o tema, mas sim contribuir a partir da análise da Rede de Atenção Psicossocial para o atendimento no âmbito do hospital universitário, como também na mobilização dos serviços do território e, com isso, possibilitar condições para a superação das vulnerabilidades ${ }^{3}$ que incidem tanto nos recém-nascidos quanto nas puérperas na perspectiva da convivência familiar pela formação de vínculos com a sua família de origem ou a construção de uma nova família com o seu filho.

\footnotetext{
2 Por território entende-se: "Trata-se de um conceito que extrapola os sentidos meramente geográficos ou regionais, mas tem relação com as redes de relações e afetos e com as redes sociais daquele que é cuidado, que inclui a família, os vizinhos, a escola, a praça, o clube, os lugares de lazer etc. (BRASIL, 2014, p. 25-26). "O território é o lugar psicossocial do sujeito; é onde a vida acontece" (BRASIL, 2005, p. 13 apud BRASIL, 2014, p. 26).

${ }^{3}$ A vulnerabilidade será tratada em conformidade com a Política Nacional de Assistência Social de 2004: "Constitui o público usuário da Política de Assistência Social, cidadãos e grupos que se encontram em situações de vulnerabilidade e riscos, tais como: famílias e indivíduos com perda ou fragilidade de vínculos de afetividade, pertencimento e sociabilidade; ciclos de vida; identidades estigmatizadas em termos étnico, cultural e sexual; desvantagem pessoal resultante de deficiências; exclusão pela pobreza e, ou, no acesso às demais políticas públicas; uso de substâncias psicoativas; diferentes formas de violência advinda do núcleo familiar, grupos e indivíduos; inserção precária ou não inserção no mercado de trabalho formal e informal; estratégias e alternativas diferenciadas de sobrevivência que podem representar risco pessoal e social" (2004, p. 33).
} 


\section{Família(s) e políticas sociais: de quem é a responsabilidade?}

\section{1. \\ Análise sobre as influências das transformações societárias nas famílias}

Acredita-se que a temática em questão necessita de uma compreensão para além da droga em si, ou seja, é de suma importância a observação do usuário, do meio onde ele vive, dos estigmas e preconceitos que permeiam esse universo. Sendo assim, pelo fato de a família constituir o primeiro espaço de socialização do sujeito, e ainda, a base para a construção dos valores do indivíduo, inicialmente, propõe-se discorrer sobre alguns aspectos das histórias das organizações familiares e de que forma as transformações societárias influenciam o seu meio.

A expressão "família" foi inventada pelos romanos, oriunda da expressão latina famulus, que significa "escravo doméstico", referente aos escravos que trabalhavam na agricultura familiar das tribos ladinas, situadas na atual Itália (Miranda, 2001, p. 57-58).

No estudo das estruturas elementares do parentesco, Mioto (2004) afirma com base na obra de Lévi-Strauss (1976) que a família surgiu no atrelamento entre natureza e a cultura com a invenção do tabu do incesto, permitindo, assim, a afirmação da supremacia da regra cultural da afinidade sobre a natural da consanguinidade.

Segundo Engels (1982), a evolução da família consistiu na substituição de tribos para círculos menores em cuja essência predominava a comunidade conjugal entre os sexos. Para o autor, há três fases clássicas da evolução da cultura: o Estado Selvagem significava a estruturação por grupos pelos quais cada homem pertencia a todas as mulheres, e cada mulher pertencia a todos os homens; a Barbárie, que corresponderia a família sindiásmica, caracterizada pela redução do grupo a sua unidade última que é o par, ou seja, o casal; e a Civilização, que tem como modelo a monogamia, baseada no predomínio do 
homem e cujo objetivo expresso é o de procriação dos filhos e a preservação da riqueza por meio da herança.

De acordo com o autor, a passagem para a monogamia é "para assegurar a fidelidade da mulher e, por conseguinte, a paternidade dos filhos, aquela é entregue, sem reservas, ao poder do homem: quando este a mata, não faz mais do que exercer o seu direito" (Engels, 1982, p. 19). Esse tipo de família concretiza o predomínio do homem e, consequentemente, a subordinação da mulher. Com isso, surge o patriarcado, designando um novo organismo social, cujos membros viviam sob a liderança do ancestral comum, o patriarca, ou seja, havia o poder exclusivo do homem no interior da família. Com relação à mulher, essa era representada para os homens apenas como a mãe dos seus filhos.

Com relação à monogamia, Mioto alega que é fundada no princípio natural da filiação. No âmbito da hereditariedade, a autora afirma que essa só foi possível posteriormente quando se descobriu a "relação entre o ato sexual e a filiação" (2004, p. 116).

A autoridade do homem e a submissão da mulher como dona do lar e cuidadora dos filhos são a base do modelo da família nuclear burguesa, a qual desenvolveu-se no Brasil, no início do século XIX, com a ideia de "civilizar", ou seja, "afrancesar" a sociedade escravocrata, mestiça e luso-tropical, conforme D`Incao (1997). Nesse período, até a arquitetura das cidades procurava tornar o convívio familiar mais íntimo, tendenciando o fechamento da família sobre si mesma, o que a autora supracitada chama de processo de privatização da família, marcado pela valorização da intimidade. Para Bruschini (1993) apud Morgado (2012), "a família nuclear burguesa, com seu modelo de assimetria sexual, não é um modelo único ou norma universal, mas sim um fenômeno historicamente construído" (2012, p. 112).

Ainda nesse sentido, Oliveira (2011) discorre que para Castel (1998) com o aparecimento da família burguesa "surge a prática de fechamento em si mesma, estabelecendo distâncias em relação à comunidade e aos parentes, emergindo a noção de privacidade familiar" (2011, p. 56). No aspecto de gênero, o autor acrescenta que esse modelo familiar:

(...) opera-se com a crescente dependência das mulheres em relação a seus maridos para seu sustento, oportunizando o exercício de estrito controle sobre seus corpos e sua sexualidade, destituindo-lhes o direito ao prazer e circunscrevendo-as à procriação (Oliveira, 2011, p. 56). 
Para Morgado (2012), esse modelo de família tem como uma das principais características "a naturalização da divisão sexual do trabalho, trazendo com ela a fixa distinção de papéis entre $o$ homem/provedor e a mulher/cuidadora" (2012, p. 113). A autora indica que no Brasil,

(...) somente na segunda metade da década de 1970 que, com o maior poder de pressão alcançado pelos movimentos feministas, em consonância com as conquistas de redemocratização da sociedade, as funções tradicionalmente desempenhadas por homens e mulheres na família puderam, de modo mais contundente, ser questionada (2012, p. 120).

Mioto acrescenta que esses questionamentos alteraram inclusive o caráter das relações matrimoniais, "institui a possibilidade de dissolução do casamento, a relação homem/mulher deixou de ter o caráter de eternidade para 0 de temporalidade" (2004, p. 120). Com relação a esse assunto, ressaltam-se inegáveis avanços no Código Civil Brasileiro - Lei no. 10.406 de 10/02/2002 -, como nos seguintes artigos:

Art. 1.511: O casamento estabelece comunhão plena de vida, com base na igualdade de direitos e deveres dos cônjuges;

$\S 2$ do art. 1565: O planejamento familiar é de livre decisão do casal, competindo ao Estado propiciar recursos educacionais e financeiros para o exercício desse direito, vedado qualquer tipo de coerção por parte de instituições privadas ou públicas.

Art. 1.566: São deveres de ambos os cônjuges: I - fidelidade recíproca; II - vida em comum, no domicílio conjugal; III - mútua assistência; IV - sustento, guarda e educação dos filhos; $V$ - respeito e consideração mútuos.

Art. 1.567: A direção da sociedade conjugal será exercida, em colaboração, pelo marido e pela mulher, sempre no interesse do casal e dos filhos.

$\S 2$ ○ do art. 1583: Na guarda compartilhada, o tempo de convívio com os filhos deve ser dividido de forma equilibrada com a mãe e com o pai, sempre tendo em vista as condições fáticas e os interesses dos filhos. (grifos nossos).

Não obstante os avanços das mulheres, a condição de subalternidade ainda se encontra presente na atual sociedade, o que, de acordo com Morgado contribui "para subsidiar a ideia de que as relações sociais familiares comportam "permanências e mudanças'” (2012, p.122). Nas palavras da autora, 
A sociedade brasileira, herdeira de um sistema patriarcal, continua conferindo ao homem um lugar de privilégios, seja como marido/companheiro, seja como pai. Assim, a atribuição de funções em nossa sociedade, determinada pelas condições de inserção de classe, gênero e etnia, configura uma inserção subordinada da mulher (Morgado, 2012, p. 37).

As mudanças apresentadas no modelo tradicional familiar juntamente com o agravamento da questão social ${ }^{4}$, face à crise econômica nos anos 80 e o advento neoliberal ${ }^{5}$ na década posterior trouxeram impactos na construção da família brasileira: queda no tamanho das famílias ${ }^{6}$; perda da importância do arranjo "casal com filhos"; crescimento das famílias monoparentais, um grande contingente de crianças e mulheres no mercado de trabalho devido à migração exacerbada do campo para a cidade, entre outros. Por isso, para Mioto (2004), devemos nos referir a famílias no plural, devido a sua multiplicidade de tipos existentes hoje na sociedade brasileira. O mundo familiar é palco de múltiplas interpretações em um modo particular, criando uma "cultura" familiar própria.

Observa-se que muitas vezes, dentro da mesma casa, coabita mais de um grupo familiar e até mesmo famílias formadas a partir de segundas uniões, as chamadas famílias recombinadas, conforme Giddens (1993). Acrescentam-se ainda os seguintes tipos de organização: casal sem filhos e casais compostos por pessoas do mesmo sexo. Assim, essas novas concepções de famílias passaram a ser estabelecidas pela valorização do afeto por meio do respeito entre os seus membros. Ressalta-se que apesar da "aceitação" da existência de uma multiplicidade de arranjos familiares, a sociedade tem a família nuclear burguesa como "modelo natural de união" (Morgado, 2012, p. 124).

Nesse diapasão, o próprio direito, no $\S 3^{\circ}$ do art. 226 da Constituição Federal de 1988 (CRFB/88), reconhece que a família não se constitui apenas pelo casamento, como também, "pelo grande número de famílias não matrimonializadas, oriundas de uniões estáveis, ao lado de famílias

\footnotetext{
${ }^{4}$ A questão social é compreendida como "o conjunto das expressões das desigualdades da sociedade capitalista madura, que tem uma raiz comum: a produção social é cada vez mais coletiva, o trabalho torna-se mais amplamente social, enquanto a apropriação dos seus frutos mantém-se privada, monopolizada por uma parte da sociedade" (IAMAMOTO, 2005, p. 27).

5 Tauile (2001) relata que o neoliberalismo iniciou-se de fato no Brasil a partir de 1990, por meio da vitória de Fernando Collor de Mello, o qual tinha um discurso calcado em uma vaga e falsa ideia de modernidade, especialmente vista sob o ângulo econômico. Contudo, o aprofundamento do contexto neoliberal no Brasil foi através do governo de Fernando Henrique Cardoso e os seus traços mais marcantes foram a abertura do mercado brasileiro às importações de produtos estrangeiros e o desmonte do aparelho de Estado, com destaque para o processo de privatizações.

${ }^{6}$ Rizzini analisa que um dos indicadores para que as famílias tendem a ser menores é o declínio da taxa de fertilidade, que pode ser explicada "pelo maior acesso a contraceptivos, ao sistema de saúde e de educação e as oportunidades econômicas por parte das mulheres" (2001, p. 28).
} 
monoparentais, que denota a abertura de possibilidade às pessoas, para além de um único modelo" (Fachin, 2001, p. 20). Essa multiplicidade de configurações faz com que ocorra uma necessidade de se discutir família para além do espaço restrito a um domicílio único, conforme Nogueira e Monteiro (2013).

Neste estudo, a conceituação de "família" terá como embasamento Mioto que define família como "uma instituição historicamente condicionada e dialeticamente articulada com a estrutura social na qual está inserida" (2004, p. 118).

Outra definição a ser considerada é a da Norma Operacional Básica do Sistema Único de Assistência Social (NOB/SUAS) que afirma: "Núcleo afetivo, vinculada por laços consanguíneos, de aliança ou afinidade, onde os vínculos circunscrevem obrigações recíprocas e mútuas, organizadas em torno de relações de geração e de gênero" (2005, p. 19).

Compreendendo a unidade familiar sob a perspectiva apresentada, será realizada a seguir uma reflexão sobre a relação família e políticas públicas. Iniciamos por citar a Constituição da República Federativa do Brasil de 1988 que em seu art. 227, enuncia:

\begin{abstract}
É dever da família, da sociedade e do Estado assegurar à criança, ao adolescente e ao jovem, com absoluta prioridade, o direito à vida, à saúde, à alimentação, à educação, ao lazer, à profissionalização, à cultura, à dignidade, ao respeito, à liberdade e à convivência familiar e comunitária, além de colocá-los a salvo de toda forma de negligência, discriminação, exploração, violência, crueldade e opressão.
\end{abstract}

Portanto, verifica-se que houve um deslocamento, uma atribuição importante de centralidade, de responsabilidade para as famílias. No entanto, as famílias, sobretudo as pobres, são constantemente culpabilizadas quando não conseguem "dar conta" da proteção dos seus membros. Esse fato contrapõe-se à responsabilidade do Estado expressa em nossa Carta Magna em seu art. 227 e não leva em consideração a ausência de políticas públicas que propiciem a superação das vulnerabilidades em que essas famílias se encontram. Tais questões serão discutidas no item a seguir. 


\section{2. \\ As políticas sociais no contexto neoliberal e seus impactos na família}

As condições históricas e as transformações sociais, econômicas e políticas interferem na família, criando condutas e valores que serão transmitidos para as futuras gerações. Elas têm impacto na forma como a família irá se organizar para cumprir sua função social. Como Mioto afirma, "a dinâmica relacional estabelecida em cada família não é dada, mas é construída a partir de sua história e de negociações cotidianas que ocorrem internamente entre seus membros e externamente com o meio social mais amplo" (2004, p. 117).

No cenário brasileiro, enfatiza-se o discurso da centralidade das famílias na agenda das políticas sociais. Apesar disso, as legislações e os programas dificilmente pensam a família dentro de uma lógica de totalidade/unidade, mas sim de maneira fragmentada com respostas individualizadas, voltadas para públicos específicos como criança e adolescente, idoso, deficiente, entre outros. Para se compreender o viés das políticas sociais brasileiras, sugere-se, inicialmente, uma análise acerca da proteção social tendo como plano de fundo o contexto internacional.

Sobre as políticas sociais, Behring e Boschetti apontam que "sua origem é comumente relacionada aos movimentos de massa social-democratas e ao estabelecimento dos Estados-nação na Europa ocidental do final do século XIX" (Pierson, 1991 apud Behring \& Boschetti, 2008, p. 47). Contudo, as políticas sociais tornam-se evidentes no período pós-guerras, com o Welfare State, o Estado de bem-estar social, o chamado "os anos dourados" ou "as três décadas gloriosas", conforme Braz e Netto (2006). Esse modo de intervenção estatal procurava restabelecer o equilíbrio econômico-social europeu, abalado pelas guerras. As formas utilizadas por este Estado interventor foram a utilização do modelo de produção taylorista-fordista ${ }^{7}$ e 0 incremento de políticas públicas.

\footnotetext{
7 Para Vesentini (1996), o taylorismo é a organização do trabalho sistematizada pelo engenheiro norte-americano Taylor por volta de 1900 , consistindo na rígida separação do trabalho por tarefas e níveis hierárquicos (executivos e operários). Existe um controle sobre o tempo gasto em cada tarefa e no esforço de racionalização, de forma que a tarefa seja executada num tempo mínimo. O tempo de cada trabalhador passa a ser vigiado e cronometrado, e há o incentivo de prêmios para aqueles que produzem mais em menos tempo, aumentando, assim, a exploração do trabalhador. Apesar de esse método ser bastante lógico do ponto de vista do capital, ignorava os efeitos do cansaço e os aspectos fisiológicos e psicológicos, influenciando, assim, a vida dos trabalhadores. Já o fordismo, cujo nome vem do industrial norte-americano Ford, um pioneiro da indústria automobilística, surge com métodos voltados para a produção em massa. Dessa forma, organiza uma linha de montagem de cada fábrica de forma a produzir mais, controlando as fontes de
} 
Conjugada a esse modo de produção, emerge a Ideologia Keynesiana, a qual, segundo Pazzinato e Senise (1994), consiste numa organização políticoeconômica, oposta às concepções neoliberais, fundamentada na afirmação do Estado como agente de controle total ou majoritário da economia, com objetivo de conduzir a um sistema de pleno emprego. Tais ideias tiveram enorme influência na renovação das teorias clássicas e na reformulação da política de livre mercado.

As análises de Behring e Boschetti (2008) mostram que, no Brasil, as políticas sociais nascem e se desenvolvem na perspectiva de enfrentamento da questão social e seus períodos de expansão foram no varguista (1937-1945) e no ditatorial (1964-1984), contudo, numa ótica clientelista/assistencialista, ou seja, não havia o reconhecimento de direitos, mas sim um controle social. Para alguns autores, como Oliveira (2003), o Welfare State no Brasil não existiu na realidade. Pelo contrário, emergiu um Estado de mal-estar social em razão da formação política do país. É como se o país estivesse à parte dessas macrotransformações.

A partir da década de 70, uma crise mundial rompe com o compromisso do Welfare State, tendo como principal fator a crise do petróleo, a qual acarretou a queda da taxa de lucros do capital nos países centrais, atingindo o padrão de acumulação fordista, tendo em vista que trouxe consigo, como efeito, índices baixos de crescimento da produção e da produtividade e, consequentemente, crescente desemprego, de acordo com Serra (2001). Diante disso, o capitalismo instaura o modelo de acumulação flexível como forma de tentativa de solução para a crise.

Antunes (2003) aponta que, dentro da perspectiva da acumulação flexível, o modelo japonês ou toyotismo ${ }^{8}$ acarretou alguns impactos, tanto pela revolução técnica que operou na indústria japonesa quanto pela potencialidade de propagação.

matérias-primas e de energia, a formação da mão-de-obra, os transportes, o aperfeiçoamento das máquinas etc.

${ }^{8}$ Para Vesentini (1996), o toyotismo introduz o just-in-time, pois a produção em massa do fordismo acarretava um grande desperdício, através desse método, a produção se dá a partir da necessidade do consumidor, fabricando-se somente o necessário e com grande controle de qualidade. Além disso, com a implantação da informática, da robótica e da força de trabalho qualificada, houve a substituição da linha de montagem por uma produção mais flexível, e as atividades se tornaram mais criativas e qualificadas. 
No Brasil, como afirma Tauile (2001), a economia foi atingida pela crise financeira internacional, levando ao prenúncio de tempos difíceis, o que fez com que a década de 1980 fosse chamada de a "década perdida". De fato, a crise brasileira foi intensificada pelas altas taxas de juros internacionais, o que elevava cada vez mais a dívida externa.

Não obstante, é imperioso ressaltar que, mesmo durante toda essa crise, a década de 80 simbolizou a redemocratização do país. Nessa conjuntura foi elaborada a Constituição da República Federativa do Brasil de 1988, a qual apresenta a seguridade social em seu art. 194 como um "conjunto integrado de ações de iniciativa dos Poderes Públicos e da sociedade, destinado a assegurar os direitos relativos à saúde, à previdência e à assistência social". Neste âmbito, como públicos dos pilares da seguridade, a saúde é voltada para todos, a previdência para os que contribuem e a assistência para os que dela necessitarem.

Para Nogueira e Monteiro, "a Constituição de 1988 foi o marco da proteção social institucionalizada, e somente a partir dessa legislação que surgem alguns direitos específicos para determinados segmentos da sociedade considerados vulneráveis" ${ }^{9 "}(2013$, p. 149).

Retomando as tentativas de solucionar a crise, Behring (2001) mostra que - capital apresenta a reestruturação produtiva ${ }^{10}$ combinada com o ajuste neoliberal. Tauile (2001) relata que o neoliberalismo iniciou-se de fato no Brasil a partir de 1990, por meio da vitória de Fernando Collor de Mello, o qual tinha um discurso calcado em uma vaga e falsa ideia de modernidade, especialmente vista sob o ângulo econômico. Contudo, o aprofundamento do contexto neoliberal no Brasil foi através do governo de Fernando Henrique Cardoso, que teve como traços mais marcantes o aprofundamento da abertura do mercado brasileiro às importações de produtos estrangeiros e o desmonte do aparelho de

\footnotetext{
9 Nogueira e Monteiro referenciam o termo vulneráveis como: "crianças e adolescentes, idosos, pessoas com deficiência e pessoas acometidas como doenças crônicas (...)" (2013, p. 149).

10 Para Antunes, a reestruturação produtiva, ao mesmo tempo em que trouxe inovações tecnológicas, também acarretou "uma diminuição da classe operária industrial tradicional. Mas, paralelamente, efetivou-se uma expressiva expansão do trabalho assalariado, a partir da enorme ampliação do assalariamento no setor de serviços; verificou-se uma significativa heterogeneização do trabalho, expressa também através da crescente incorporação do continente feminino no mundo operário; vivencia-se também uma subproletarização intensificada, presente na expansão do trabalho parcial, temporário, precário, subcontratado, 'terceirizado' (...)". (ANTUNES, 2003, p.41).
} 
Estado, com destaque para o processo de privatizações. Segundo Perry Anderson:

O neoliberalismo nasceu logo depois da II Guerra Mundial, na região da Europa e da América do Norte onde imperava o capitalismo. Foi uma reação teórica e política veemente contra o Estado intervencionista e de bem-estar. (...) Trata-se de um ataque apaixonado contra qualquer limitação dos mecanismos de mercado por parte do Estado, denunciadas como uma ameaça letal à liberdade, não somente econômica, mas também política. (Anderson, 1995, p. 9).

Nesse sentido, para lamamoto, o neoliberalismo conclama "a necessidade de reduzir a ação do Estado para o atendimento das necessidades das grandes maiorias mediante a restrição de gastos sociais, em nome da chamada crise fiscal do Estado" (2010, p. 144). Assim, observa-se que houve um retrocesso dos direitos até então conquistados, já que o mercado passa a ser o interventor do setor político e social, ou seja, há um desmonte dos mecanismos de proteção social e a privatização de bens e serviços públicos. Para Laurel (1995), houve um processo de pauperização das políticas sociais. Essas políticas foram reestruturadas por meio de três vertentes: a descentralização, a focalização e a privatização, como explicita Sonia Draibe,

(...), a descentralização é concebida como um modo de aumentar a eficiência e a eficácia do gasto, já que aproxima problema e gestão. (...) A focalização, por sua vez, significa o direcionamento do gasto social a programas e a públicos-alvo específicos, seletivamente escolhidos pela sua maior necessidade e urgência. (...), a privatização entendida como deslocar a produção de bens e serviços públicos para o setor privado lucrativo (...). (Draibe, 1993, p. 97).

Pode-se afirmar que na esfera das políticas públicas houve fragmentação no enfrentamento da questão social. Para Behring (2003), essa contrarreforma do Estado acarreta a precarização dessas políticas por transferir as suas responsabilidades para os setores da sociedade civil, pautada na ideia de que 0 público é ineficiente, e o privado é sinônimo de qualidade, apelando, assim, para a solidariedade e transformando direitos em práticas assistencialistas direcionadas à população em situação de pobreza ${ }^{11}$.

\footnotetext{
11 Utilizo a concepção de pobreza a partir de Yazbek (2012): como uma das manifestações da questão social, e dessa forma como expressão direta das relações vigentes na sociedade, localizando a questão no âmbito de relações constitutivas de um padrão de desenvolvimento capitalista, extremamente desigual, em que convivem acumulação e miséria.
} 
O que se percebe é que o neoliberalismo limitou o conceito de pobreza à renda, desconsiderando os outros condicionantes ${ }^{12}$ que possibilitam o bem-estar das pessoas. Ademais, ao invés de termos o Estado como o garantidor majoritário dos direitos sociais, na verdade, houve uma substituição do seu papel para a sociedade civil, sobretudo para a família, que aparece como a principal receptora desse encargo, assumindo o suporte material e afetivo para os seus membros. Nesse sentido, como analisa Pereira (2004), o ideário neoliberal traz a família como corresponsável do Estado no âmbito da proteção social.

Concordamos com Santos e Rifiotis quando afirmam que há uma tendência nas políticas públicas brasileiras de "reprivatização do cuidado", que é "um retorno do cuidado para o contexto domiciliar, tendo como seus executores os membros da família, também chamados de cuidadores familiares" (2006, p. 106). Neste diapasão, Carloto chama essa estratégia de "privatização da família ou privatização da sobrevivência da família" (2006, p. 145). Neste sentido, para Pereira (2004) analisa que a família assume um lugar de destaque no provimento do bem estar dos seus membros, ou seja, a família foi redescoberta como um agente substitutivo do Estado e dentro delas as mulheres.

Conforme Carloto, a tática dessas políticas centradas na família é "a entrega direta de bens ou atividades de capacitação que reforçam as habilidades consideradas adequadas às donas-de-casa e mães não-trabalhadoras" (2006, p. 145).

A concepção de centralidade na família é percebida principalmente na política de assistência social, a qual possui como diretriz a "matricialidade sociofamiliar", por meio do Sistema Único de Assistência Social (SUAS). Assim, a Política Nacional de Assistência Social (PNAS) tem como um dos seus objetivos "assegurar que as ações no âmbito da assistência social tenham centralidade na família, e que garantam a convivência familiar e comunitária" (MDS/CNAS, 2004, p. 33). Porém, a realidade é bem diferente, tendo em vista que as transformações societárias descritas no capítulo anterior parecem acentuar as condições de vulnerabilidades nos seios familiares.

Todavia, como já dito, as políticas assistenciais pautam-se em programas de combate à pobreza, realizados de maneira emergencial, focalizada, seletiva $\mathrm{e}$

12 Como condicionantes refiro-me aos direitos sociais elencados no art. 6o da Constituição da República Federativa do Brasil de 1988: "São direitos sociais a educação, a saúde, a alimentação, o trabalho, a moradia, o lazer, a segurança, a previdência social, a proteção à maternidade e à infância, a assistência aos desamparados". 
fragmentada. Dessa maneira, com frequência, os serviços são oferecidos de forma pontual e individualizada por meio de legislações específicas, como o Estatuto da Criança e do Adolescente (Lei no 8.069/90), o Estatuto do Idoso (Lei no 10.741/03), Lei da Pessoa com Deficiência (Lei no 7.853/89), entre outras. Nogueira e Monteiro acrescentam que essas fragmentações legislativas "não conseguiram contemplar uma aproximação com a totalidade do universo familiar, em sua pluralidade de arranjos e configurações, não determinando, portanto, ao Estado o efetivo investimento na promoção da família" (2013, p. 149).

Diante disso, infere-se que a centralidade da família nas políticas públicas não é realizada numa concepção ampliada, ou seja, numa visão da família como unidade, mas sim, num aspecto assistencial voltado para a resolução de problemas específicos focados em um indivíduo - "usuário-problema".

Nesse sentido, Mioto (2008) afirma que a construção histórica da relação Estado e família foi permeada pela ideologia de que cabe à família a capacidade de proteção dos seus membros. Com relação à capacidade, a autora faz uma reflexão sobre a distinção entre famílias capazes e incapazes ${ }^{13}$ :

\begin{abstract}
$\mathrm{Na}$ categoria das capazes incluem-se aquelas que, via mercado, trabalho e organização interna, conseguem desempenhar com êxito as funções que lhes são atribuídas pela sociedade. Na categoria incapazes estariam aquelas que, não conseguindo atender às expectativas sociais relacionadas ao desempenho das funções atribuídas, requerem a interferência externa, a princípio do Estado, para a proteção dos seus membros. Ou seja, são merecedores da ajuda pública as famílias que falharam na responsabilidade do cuidado e proteção dos seus membros (Mioto, 2008, p. 51).
\end{abstract}

Desta forma, percebe-se que a intervenção estatal ocorre apenas quando a família "falha" na proteção e cuidado dos seus membros. Conforme Mioto (2013) pontua, a família, juntamente com o mercado, é "um dos canais naturais de provisão de bem-estar" e apenas quando há falha desses canais "é que se dá a intervenção pública, e de forma temporária" (2013, p. 05).

$\mathrm{Na}$ verdade, essa "falha" ocorre quando não se consegue "viver" de acordo com o estabelecido pelo modelo de "família pensada", a qual Gomes (1988) apud Szymanski (1997) apresenta como:

\footnotetext{
${ }^{13}$ A autora deixa claro que essa distinção possui mero efeito expositivo, pois "na realidade, não existem essas categorias em estado puro. Nenhuma família é totalmente auto-suficiente, assim como totalmente dependente (MIOTO, 2008, p. 51).
} 
Uma união exclusiva de um homem e uma mulher, que se inicia por amor, com a esperança de que o destino lhes seja favorável e que ela seja definitiva. Um compromisso de acolhimento e cuidado para com as pessoas envolvidas e expectativa de dar e receber afeto, principalmente em relação aos filhos. Isto, dentro de uma ordem e hierarquia estabelecida num contexto patriarcal de autoridade máxima que deve ser obedecida, a partir do modelo pai-mãe-filhos estável (1997, p. 25).

Com relação à "família vivida", ou seja, a que emergiu da análise do cotidiano, a autora afirma:

Um grupo de pessoas, vivendo numa estrutura hierarquizada, que convive com a proposta de uma ligação afetiva, duradoura, incluindo uma relação de cuidado entre adultos e deles para com as crianças e idosos que aparecerem nesse contexto (Gomes, 1988 apud Szymanski,1997, p. 26).

Assim, penaliza-se a família pelas suas condições de vulnerabilidade, sem levar em consideração o contexto de desigualdade social agravado pelo novo modelo estatal - "Essa centralidade não pode significar a penalização da família, no sentido de devolver-Ihe o peso de arcar, praticamente sozinha, com a esfera da reprodução social" (Alencar, 2013, p. 143).

Por fim, considerando-se que a realidade brasileira é formada em sua grande maioria por famílias empobrecidas financeiramente ${ }^{14}$, procurou-se discutir como a falta de um suporte estatal por meio de políticas públicas dificulta ainda mais o enfrentamento às expressões das questões sociais. Neste contexto, a desconstrução da ideia de uma constante culpabilização das famílias e a sua potencialização são grandes desafios para os profissionais, principalmente aos que trabalham no âmbito da drogadição, pois, na maioria das vezes, se encontram em condições precarizadas de trabalho e contam com uma oferta de equipamentos ancorada numa frágil rede de serviços, conforme veremos a seguir.

\footnotetext{
14 Os números da Pesquisa Nacional por Amostra de Domicílios de 2012 (PNAD) mostram uma grande evolução em indicadores sociais brasileiros. A análise de alguns deles está detalhada no Comunicado do Ipea no 159, intitulado Duas décadas de desigualdade e pobreza no Brasil medidas pela PNAD/IBGE. A pesquisa revela que a população extremamente pobre (renda familiar per capita de até $R \$ 75$ ) caiu de 7,6 milhões de pessoas para 6,5 milhões. Já a população pobre (até $R \$$ 150) foi reduzida de 19,1 milhões para 15,7 milhões. In: http://www.ipea.gov.br/portal/index.php?option=com_content\&view= article\&id=19998. Acessado em 18/08/2015. Apesar da queda apresentada, percebe que o número de pessoas empobrecidas na sociedade brasileira ainda é bastante expressivo.
} 


\section{A trajetória da saúde mental na sociedade brasileira e o "tratamento" oferecido aos usuários de drogas na cidade do Rio de Janeiro}

\section{1. \\ Aspectos normativos e históricos sobre a saúde mental no Brasil com enfoque na drogadição}

Para a realização da análise sobre a atual política de drogas, se faz oportuna uma apreciação dos aspectos normativos e históricos sobre a saúde mental no Brasil. Não será realizada uma exposição exaustiva acerca desses instrumentos legais, mas sim uma discussão dos principais avanços significativos referentes à política do campo supracitado a partir da década de 70.

Partiremos de uma noção inicial sobre a Reforma Psiquiátrica, que vai de encontro aos antigos preceitos de confinamento/isolamento dos pacientes. Esse tipo de tratamento tinha como única função social a exclusão. Diante disso, Amarante (1998) afirma que o asilamento era o modelo técnico-assistencial que predominava no Brasil até finais do século $X X$, o qual era voltado para a manutenção da ordem e da moral.

Para Delgado (2001), a partir da década de 70, esse movimento buscava a luta pela superação manicomial, além do chamamento da sociedade na luta pelos direitos dos pacientes mentais.

Para Bisneto (2011), a loucura é um fenômeno antigo na história da humanidade e que, a partir da Idade Moderna, a civilização ocidental ascende o pensamento racional, fazendo com que a loucura fosse considerada como algo fora da normalidade. E no advento da Idade Contemporânea, o discurso médico se apropria da loucura, fazendo com que tudo que fosse considerado anormal passasse a ser patológico, construindo-se, assim, a noção de doença mental.

Ainda para o autor supracitado, a medicina, com sua acepção positivista, realiza seus diagnósticos de transtornos mentais baseando-se nos padrões de comportamentos sociais em uma sociedade capitalista, permeada pelos 
interesses econômicos. Assim, o que diverge da ideologia capitalista é considerado como "desvio doentio e anti-social, irracional, algo a ser curado ou então excluído" (Bisneto, 2011, p. 176). Nesse sentido, "os diferentes" eram aqueles que não seguiam o comportamento considerado socialmente "normal".

Segundo Duarte (2013), Foucault muito contribuiu para a análise dessa questão. O autor aponta que quando ocorria uma exclusão do doente mental do convívio dos "normais", esses eram afastados "dos donos da razão, dos produtivos e dos que não ameaçavam a sociedade; foram assim, sequestrados do interior de suas famílias pela ordem e pelo poder psiquiátricos para os manicômios" (2013, p. 80).

Duarte (2013) acrescenta que, de acordo com o saber psiquiátrico, as famílias não sabiam lidar com os "anormais" e que, por isso, eles deviam permanecer na via internação-hospitalização e, consequentemente, ter seus vínculos sociais e familiares rompidos. Com relação à institucionalização, o autor indica que essa prática "não se restringiu ao tratamento da loucura e dos loucos", mas também para "todo e qualquer tipo de segmentos sociais ditos assim vulneráveis, eram os orfanatos para os ditos menores, os asilos para os velhos, as colônias para os ditos leprosos, e por aí vai" (2013, p. 80).

A transição entre as décadas de 70 e 80 foi bastante significativa para a saúde do Brasil, pois em pleno período de Ditadura Militar ${ }^{15}$, surgem dois movimentos de bastante relevância: a Reforma Sanitária e a Reforma Psiquiátrica, como consta do documento apresentado à Conferência Regional de Reforma dos Serviços de Saúde Mental do Ministério da Saúde:

O início do processo de Reforma Psiquiátrica no Brasil é contemporâneo da eclosão do "movimento sanitário", nos anos 70 , em favor da mudança dos modelos de atenção e gestão nas práticas de saúde, defesa da saúde coletiva, equidade na oferta dos serviços, e protagonismo dos trabalhadores e usuários dos serviços de saúde nos processos de gestão e produção de tecnologias de cuidado (Brasil, 2005, p. 06).

De acordo com Arouca (1998), a Reforma Sanitária brasileira nasceu na luta contra a ditadura, com o tema Saúde e democracia, e estruturou-se nas universidades, no movimento sindical, em experiências regionais de organização

\footnotetext{
${ }^{15}$ A Ditadura Militar no Brasil foi o regime instaurado em 1 de abril de 1964 e que durou até 15 de março de 1985. De caráter autoritário e nacionalista, teve início com o golpe militar que derrubou o governo de João Goulart, 0 então presidente democraticamente eleito. http://pt.wikipedia.org/wiki/Ditadura_militar_no_Brasil_\%281964-1985\%29. Acessado em $12 / 02 / 2015$
} 
de serviços. Esse movimento social consolidou-se na $8^{\text {a }}$ Conferência Nacional de Saúde, em 1986, na qual, pela primeira vez, mais de cinco mil representantes de todos os seguimentos da sociedade civil discutiram um novo modelo de saúde para o Brasil. O resultado foi garantir na Constituição, por meio de emenda popular, que a saúde é um direito do cidadão e um dever do Estado ${ }^{16}$.

Para Scheffer e Silva (2014) essa mobilização teve como referência a reforma psiquiátrica italiana ${ }^{17}$, protagonizada por Franco Basaglia, que fazia críticas ao cunho isolacionista dos tratamentos que eram oferecidos pelos hospitais psiquiátricos. Posto isso, as autoras citam as propostas do movimento dos trabalhadores para a melhoria da rede ambulatorial e de saúde mental:

A extinção dos leitos em hospitais psiquiátricos; a regionalização do atendimento e nas ações em saúde mental; controle das internações na rede dos hospitais e nos serviços privados e públicos; expansão da rede ambulatorial em saúde com equipes multiprofissionais de saúde mental (2014, p. 368).

Voltaremos a essa equipe multiprofissional quando discutirmos sobre a intersetorialidade e a interdisciplinaridade.

O movimento exposto era chamado de Movimento dos Trabalhadores em Saúde Mental (MTSM) e tinha como membros "integrantes do movimento sanitário, associações de familiares, sindicalistas, membros de associações de profissionais e pessoas com longo histórico de internações psiquiátricas" (Brasil, 2005, p. 07). Esses protagonistas denunciavam a violência nos manicômios e criticavam o chamado "saber psiquiátrico" e o "modelo hospitalocêntrico na assistência às pessoas com transtornos mentais" (Brasil, 2005, p. 07).

Em 1986, houve um importante acontecimento para a saúde mental no Brasil que foi a criação do primeiro Centro de Atenção Psicossocial - CAPS: “(...) foi inaugurado em março de 1986, na cidade de São Paulo - Centro de Atenção Psicossocial Professor Luiz da Rocha Cerqueira, conhecido como CAPS da Rua Itapeva" (Brasil, 2004, p. 12).

A partir desses episódios, a saúde mental na sociedade brasileira entra em um novo momento, principalmente em decorrência da I Conferência Nacional de

\footnotetext{
${ }^{16} \mathrm{http}: / /$ bvsarouca.cict.fiocruz.br/sanitarista05.html. Acessado em 13/02/2015.

17 A partir da segunda metade do século XX, impulsionada principalmente por Franco Basaglia, psiquiatra italiano, inicia-se uma radical crítica e transformação do saber, do tratamento e das instituições psiquiátricas. Esse movimento inicia-se na Itália, mas tem repercussões em todo o mundo e muito particularmente no Brasil. http://www.ccs.saude.gov.br/vpc/reforma.html. Acessado em 12/02/2015.
} 
Saúde Mental em $1987^{18}$. Pelo relatório final da conferência verifica-se grande influência da reforma sanitária a partir de uma conceituação ampliada de saúde, além da alteração do modelo assistencial voltado para a desinstitucionalização, como indicado abaixo:

2. Com referência ao modelo assistencial: 2.1. Reversão da tendência "hospitalocêntrica e psiquiatrocêntrica", dando prioridade ao sistema extrahospitalar e multiprofissional como referência assistencial ao paciente, inserindose na estratégia de desospitalização. 2.2. A partir desta Conferência, o setor público não credenciará nem instalará novos leitos psiquiátricos em unidades psiquiátricas hospitalares tradicionais, reduzindo, progressivamente, os leitos existentes nesse último tipo de serviço e substituindo-os por leitos psiquiátricos em hospitais gerais públicos ou por serviços inovadores alternativos à internação psiquiátrica. 2.2.1. Será proibida a construção de novos hospitais psiquiátricos tradicionais (Ministério da Saúde, 1988, p. 18).

Ao realizar a leitura do relatório final da conferência ora em questão, considera-se relevante lançar o tópico que abrange a responsabilidade do tratamento para a equipe multiprofissional em detrimento do único saber - o psiquiátrico. Além disso, destaca-se a abertura da possibilidade de indagações por outros segmentos: "A decisão sobre diagnóstico, tratamento e regime de tratamento é da responsabilidade da equipe assistencial multiprofissional e pode ser legalmente questionada pelo cliente, familiares ou entidades civis" (Ministério da Saúde, 1988, p. 24).

Acrescenta-se que nasceu do MTSM o Movimento da Luta Antimanicomial com o lema "por uma sociedade sem manicômios", conforme Lüchmann e Rodrigues (2007). Por esse lema denunciavam-se os tratamentos desumanos que ocorriam nos manicômios e objetivava-se a instalação de serviços alternativos e, consequentemente, o resgate da cidadania.

Em 1988, a Constituição da República Federativa do Brasil de 1988 (CRFB/88) cria o Sistema Único de Saúde (SUS) e reconhece a saúde como um direito universal, colocando o Estado como garantidor deste direito. E dois anos depois, foi sancionada a Lei Orgânica de Saúde - nº. 8080/90 que: "Dispõe sobre as condições para a promoção, proteção e recuperação da saúde, a organização e o funcionamento dos serviços correspondentes e dá outras providências". Ademais, a Carta Magna expressa a saúde como um direito fundamental e tem

\footnotetext{
${ }^{18} \mathrm{http}: / /$ bvsms.saude.gov.br/bvs/publicacoes/0206cnsm_relat_final.pdf. Acessado em 15/02/2015.
} 
como alguns dos seus princípios a universalidade, a integralidade da assistência e a participação da comunidade.

No ano de 1989, o deputado do Partido dos Trabalhadores (PT) de Minas Gerais, Paulo Delgado, criou o projeto de lei no. 3657/90, o qual dispõe "sobre a extinção progressiva dos manicômios e sua substituição por outros recursos assistenciais e regulamenta a internação psiquiátrica compulsória". No entanto, a sua aprovação não foi de imediato, pois as internações eram muito lucrativas para os donos dos hospitais psiquiátricos. Destaca-se que esse projeto foi a grande inspiração da Lei Nacional da Reforma Psiquiátrica (Lei no. . 10.216/01).

O psiquiatra Paulo Amarante ${ }^{19}$, em uma entrevista realizada em setembro de 2006, relatou sobre a dificuldade para a aprovação do supracitado projeto de lei:

Tudo levava a crer que o projeto seria aprovado num piscar de olhos, mas não foi. As associações dos proprietários de hospitais perceberam o risco que a lei representava para seus negócios milionários e organizaram lobbies em Brasília. Além disso, alarmaram os parentes dos internos (em geral tão carentes e desassistidos quanto a maioria da população), fazendo-os crer que os pacientes seriam devolvidos - da noite para dia - caso o projeto de lei fosse aprovado. $\mathrm{O}$ tiro, no entanto, saiu pela culatra. $O$ debate acabou repercutindo positivamente na opinião pública. A mais antiga associação de parentes e usuários, a Sosintra, do Rio de Janeiro, tomou a frente na defesa da reforma psiquiátrica e fortaleceu a posição contra os manicômios. Leis do mesmo tipo foram aprovadas em diversos estados. Experiências de desmontagem de estruturas manicomiais passaram a ser implantadas pelos quatro cantos do país. A transformação do modelo virou prática política e social antes mesmo de virar lei, a despeito do fato de muitas das experiências não vingarem no Brasil. A da reforma psiquiátrica veio a reboque das práticas inovadoras que a anteciparam.

Em 1990, realizou-se a Conferência de Caracas $^{20}$, promovida pela Organização Mundial de Saúde (OMS) e pela Organização Panamericana de Saúde (OPAS). Essa conferência transformou-se em referência fundamental nas Américas para o processo de transformação do modelo de atenção à saúde mental. No ano seguinte, a Assembleia Geral da Organização das Nações Unidas adota os Princípios para a Proteção dos Enfermos Mentais e para a Melhoria da Atenção à Saúde Mental.

\footnotetext{
19 Paulo Amarante é psiquiatra, doutor em saúde pública, pesquisador da Fundação Oswaldo Cruz (Fiocruz) e professor da Escola Nacional de Saúde Pública (ENSP), ambas no Rio de Janeiro. É autor de Loucos pela vida - A reforma psiquiátrica no Brasil (Editora Fiocruz, 2005), membro da diretoria do Centro Brasileiro de Estudos de Saúde (CEBES) e editor da revista Saúde em Debate. A entrevista encontra-se no site: http://www2.uol.com.br/vivermente/reportagens/rumo_ao_fim_dos_manicomios_5.html. Acessado em 18/02/2015.

20 http://bvsms.saude.gov.br/bvs/publicacoes/2conf_mental.pdf. Acessado em 18/02/2015.
} 
Em 1992, houve a II Conferência Nacional de Saúde Mental ${ }^{21}$, que tinha na atenção integral e a cidadania os direcionamentos para as suas deliberações. Com relação às drogas, questão importante para o caso das mulheres em foco nessa dissertação, essa Conferência traz o seguinte aspecto: "Assegurar que seja discriminalizado o usuário e dependente de drogas, não cabendo procedimentos penais, mas sim encaminhamento para assistência à saúde" (Ministério da Saúde, 1998, p. 29).

No Brasil, a partir do compromisso firmado com a Declaração de Caracas e a II Conferência Nacional de Saúde Mental é que passaram a vigorar as primeiras normativas que regulamentaram os serviços de atenção diária, como os CAPS, e que fiscalizavam os hospitais psiquiátricos.

Após vários anos de luta, somente em 06 de abril de 2001 é sancionada a Lei $n^{\circ}$. 10.216 que dispõe "sobre a proteção e os direitos das pessoas portadoras de transtornos mentais e redireciona o modelo assistencial em saúde mental". Pode-se afirmar que a referida lei tornou-se um instrumento efetivo para o desenvolvimento de ações que viabilizem a garantia dos preceitos da Reforma Psiquiátrica.

Inicialmente, a Lei no. 10.216/01 enumera os direitos da pessoa portadora de transtorno mental da seguinte forma:

\begin{abstract}
I - ter acesso ao melhor tratamento do sistema de saúde, consentâneo às suas necessidades; II - ser tratada com humanidade e respeito e no interesse exclusivo de beneficiar sua saúde, visando a alcançar sua recuperação pela inserção na família, no trabalho e na comunidade; III - ser protegida contra qualquer forma de abuso e exploração; IV - ter garantia de sigilo nas informações prestadas; $V$ - ter direito à presença médica, em qualquer tempo, para esclarecer a necessidade ou não de sua hospitalização involuntária; VI - ter livre acesso aos meios de comunicação disponíveis; VII - receber o maior número de informações a respeito de sua doença e de seu tratamento; VIII - ser tratada em ambiente terapêutico pelos meios menos invasivos possíveis; IX - ser tratada, preferencialmente, em serviços comunitários de saúde mental. (Lei oㅜ. 10.216/01)
\end{abstract}

Além disso, a Lei №. 10.216/01 traz para o Estado a responsabilidade do desenvolvimento da política de saúde mental, contando com a participação da sociedade e da família. Com relação à internação, esta é apresentada como uma solução de última instância, ou seja, apenas quando os recursos de outras formas de tratamento se tornarem escassos e aponta como prioridade a reinserção social: "Art. $4^{\circ}$ - A internação, em qualquer de suas modalidades, só

${ }^{21}$ http://bvsms.saude.gov.br/bvs/publicacoes/2conf_mental.pdf. Acessado em 21/02/2015. 
será indicada quando os recursos extra-hospitalares se mostrarem insuficientes". Como modalidades dos tipos de internação psiquiátrica, o parágrafo único do art. $6^{\circ}$ apresenta: "I - voluntária: aquela que se dá com o consentimento do usuário; II - involuntária: aquela que se dá sem o consentimento do usuário e a pedido de terceiro; e III - compulsória: aquela determinada pela Justiça".

Nesse mesmo ano, ocorreu a III Conferência Nacional de Saúde Mental 22 que tinha como tema "Cuidar, sim. Excluir, não. - Efetivando a Reforma Psiquiátrica com acesso, qualidade, humanização e controle social". Assim, buscava-se a criação de estratégias para um modelo de atenção em saúde mental que substituísse o tratamento manicomial. Em seus princípios e diretrizes a aludida conferência alega:

\begin{abstract}
A efetivação da Reforma Psiquiátrica requer agilidade no processo de superação dos hospitais psiquiátricos e a concomitante criação da rede substitutiva que garanta o cuidado, a inclusão social e a emancipação das pessoas portadoras de sofrimento psíquico. Nesta perspectiva é necessário que os municípios desenvolvam, de acordo com as diretrizes acima expostas, políticas de saúde mental mediante a implementação de uma rede de serviços substitutivos ao hospital psiquiátrico, territorializados e integrados à rede de saúde que realize ações de proteção, promoção, prevenção, assistência e recuperação em saúde mental (Sistema Único de Saúde, 2002, p. 23-24).
\end{abstract}

A questão do trabalho em rede, assunto de especial relevância para este estudo, aparece com grande destaque ao longo do relatório final da conferência, principalmente no capítulo que aborda a desinstitucionalização:

Garantir a criação de uma rede de atenção às pessoas com transtornos mentais, à criança e ao adolescente, aos usuários de álcool e drogas e à população de rua, de acordo com suas necessidades, considerando os dados epidemiológicos e a realidade local de cada município, enfocando: atenção integral, território, acesso, gratuidade e intersetorialidade. Esta rede deve contemplar: estruturação da atenção básica em saúde mental; ampliação da rede substitutiva territorializada com CAPS e NAPS capazes de acolher e cuidar no momento de crise, preferencialmente com funcionamento 24 horas, e outros serviços como hospitaldia, serviços de pronto-atendimento e residências terapêuticas; garantia de leitos de curta duração em hospitais gerais como estratégia, visto que a rede de atenção deve trabalhar com a perspectiva de extinção da internação psiquiátrica em qualquer de suas formas; estabelecimento de responsabilidade e coresponsabilidade entre os diferentes servicos e atores que compõem a rede. (Sistema Único de Saúde, 2002, p. 41 - grifos nossos).

Tanto a Lei n‥ 10.216/01 quanto a III Conferência Nacional de Saúde Mental trouxeram uma maior visibilidade e subsídios para a política de saúde mental brasileira, propiciando a construção de uma rede de atenção à saúde

22 http://conselho.saude.gov.br/biblioteca/relatorios/saude_mental.pdf. Acessado em 21/02/2015. 
mental com o fim de substituir o modelo cruel e devastador de internação hospitalar, conforme apresentado.

Tendo como foco no presente estudo as puérperas usuárias de drogas, faz-se necessária uma discussão sobre as políticas de drogas na sociedade brasileira. Cabe lembrar que o trabalho em tela não esgotará toda a legislação sobre o tema, mas sim abordará alguns dos marcos normativos e históricos que foram indispensáveis para as ações governamentais.

Historicamente, o tema drogas sempre esteve associado à criminalidade, preconceitos e estigmas e, ainda, a tratamentos de exclusão do convívio social. Ratificando o exposto, verifica-se que, já no início do século $X X$, havia repressão às drogas, pois a venda de ópio e seus derivados e cocaína era proibida, e a transgressão sujeitava à pena de prisão. Santos e Oliveira apontam que:

Diante da influência internacional e frente à emergente demanda social para o controle do consumo, em 1924, foi incluído no Código Penal Brasileiro, o Decreto 4.294, que propôs pena de prisão para aqueles que vendessem ópio e seus derivados e cocaína, e do Decreto 14.969, que criou o "sanatório para toxicômanos" (2012, p. 85).

As autoras supracitadas acrescentam que o Estado Brasileiro assume o papel coercitivo por influência internacional, principalmente pelos Estados Unidos da América (EUA) com sua política proibicionista em decorrência do crescente consumo de bebidas alcoólicas no país. Ressalta-se que não apenas o Brasil, mas também outros países incorporaram o lema americano de "guerra às drogas".

Na década de 30, foi promulgada a Lei de Fiscalização dos Entorpecentes (Decreto-Lei no. 891/38), posteriormente sendo incorporada ao Código Penal de 1940 (Decreto-Lei ํ․ 2.848/40) por meio do art. 281, o qual se encontra revogado. A lei expressa de forma bastante clara o posicionamento proibicionista do Estado brasileiro e a perspectiva criminalizadora.

Alves (2009) aponta que, na década de 70, as medidas instituídas pela legislação brasileira no trato das abordagens de prevenção e de repressão ao tráfico e uso de drogas ilícitas foram realizadas em conformidade com as convenções da Organização das Nações Unidas (ONU), ocorridas em 1961 
(Convenção Única sobre Entorpecentes) ${ }^{23}$ e 1971 (Convenção sobre Substâncias Psicotrópicas) ${ }^{24}$, as quais tiveram como objetivo regulamentar o controle internacional a fim de garantir as substâncias psicotrópicas para uso médico e científico e prevenir sua distribuição irregular.

Assim, em 1971, a Lei ํo. 5.726 tratava sobre medidas preventivas e repressivas ao tráfico e uso de substâncias entorpecentes ou que determinam dependência física ou psíquica e dava outras providências. Essa era mais uma lei voltada apenas para a proibição e punição dos usuários de drogas, além do isolamento deles como forma de tratamento, ou seja, inserção em hospitais psiquiátricos para "a recuperação dos infratores viciados", conforme título apresentado pela norma.

Quando o Juiz absolver o agente, reconhecendo que, em razão do vício, não possui êste a capacidade de entender o caráter ilícito do fato ou de determinar-se de acôrdo com esse entendimento, ordenará sua internação em estabelecimento hospitalar para tratamento psiquiátrico pelo tempo necessário à sua recuperação (Art. 10 da Lei ํ․ 5.726/71).

Em 1976, a Lei ํo. 5.726/71 é revogada pela Lei №. 6.368/76 que dispunha sobre medidas de prevenção e repressão ao tráfico ilícito e uso indevido de substâncias entorpecentes ou que determinam dependência física ou psíquica, e dava outras providências. O público-alvo passa a ser "os dependentes de substâncias entorpecentes, ou que determinem dependência física ou psíquica" e não os "viciados infratores". Não obstante, mais uma vez a internação surge como primordial para o tratamento, vide art. 10 da referida lei, "o tratamento sob regime de internação hospitalar será obrigatório quando o quadro clínico do dependente ou a natureza de suas manifestações psicopatológicas assim o exigirem" (Art. 10 da Lei no. 6.368/76).

\footnotetext{
${ }^{23}$ Esta convenção tem o objetivo de combater o abuso de drogas por meio de ações internacionais coordenadas. Existem duas formas de intervenção e controle que trabalham juntas: a primeira é a limitação da posse, do uso, da troca, da distribuição, da importação, da exportação, da manufatura e da produção de drogas exclusivas para uso médico e científico; a segunda é combater o tráfico de drogas por meio da cooperação internacional para deter e desencorajar os traficantes. http://www.unodc.org/lpo-brazil/pt/drogas/marco-legal.html. Acessado em 28/03/2015.

${ }^{24}$ Esta convenção estabelece um sistema de controle internacional para substâncias psicotrópicas, e é uma reação à expansão e diversificação do espectro do abuso de drogas. A convenção criou ainda formas de controle sobre diversas drogas sintéticas de acordo, por um lado, a seu potencial de criar dependência, e por outro lado, a poder terapêutico. http://www.unodc.org/lpobrazil/pt/drogas/marco-legal.html. Acessado em 28/03/2015.
} 
Criou-se a possibilidade dos serviços extra-hospitalar - $\S 1^{\circ}$ do art. 10: "Quando verificada a desnecessidade de internação, o dependente será submetido a tratamento em regime extra-hospitalar, com assistência do serviço social competente", o que, conforme Alves (2009), só aconteceu na década seguinte.

Em 1980, o Decreto no. 85.110 instituiu o Sistema Nacional de Prevenção, Fiscalização e Repressão de Entorpecentes, o qual segundo o art. 10: "integra as atividades de prevenção, fiscalização e repressão ao tráfico e uso de substâncias entorpecentes ou que determine dependência física ou psíquica, bem como as atividades de recuperação de dependentes". Além disso, a norma atribuía ao Conselho Federal de Entorpecentes (COFEN) a realização da Política Nacional de Entorpecentes. E assim continuavam tendo como foco a abstinência e o proibicionismo.

$\mathrm{Na}$ verdade, pode-se observar que a saúde pública brasileira consentiu uma lacuna nas políticas de tratamento e prevenção associados ao consumo de álcool e outras drogas por bastante tempo, deixando essa questão "para as instituições da justiça, segurança pública, pedagogia, benemerência, associações religiosas" (Ministério da Saúde, 2005, p. 40), tendo como principal objetivo a abstinência. Acrescenta-se que "as iniciativas governamentais restringiam-se a poucos serviços ambulatoriais ou hospitalares (...). Não havia uma política de alcance nacional, no âmbito da saúde pública" (Ministério da Saúde, 2005, p. 41).

Posteriormente, Garcia, Leal e Abreu (2008) citam que em 1991, o Ministério da Saúde cria o Serviço de Atenção ao Alcoolismo e à Dependência Química, sendo uma das atividades da então Coordenação de Saúde Mental. As atuações do serviço eram direcionadas à prevenção, assistência e tratamento no contexto das drogas, com o fim de reduzir a demanda crescente do consumo, mediante a fundação de um novo modelo assistencial, com ações de apoio e ampliação da rede de serviços em saúde mental.

Segundo Alves (2009), em 1998, o COFEN foi extinto e transformado em Conselho Nacional Antidrogas (CONAD), o Sistema Nacional de Prevenção, Fiscalização e Repressão de Entorpecentes foi alterado para Sistema Nacional Antidrogas (SISNAD), e foi criada pela Medida Provisória no. 1.669/98, a Secretaria Nacional Antidrogas (SENAD), diretamente vinculada à, então, Casa Militar da Presidência da República. 
Um grande evento marca o final da década de 1990 - 1․ Fórum Nacional Antidrogas, realizado em Brasília. Alves relata que "esse Fórum teve por objetivo abrir um canal de diálogo entre a sociedade e o governo federal, visando o estabelecimento de uma Política Nacional Antidrogas" (2009, p. 270).

A partir do ano 2000, expressivas transformações foram realizadas no teor da legislação brasileira sobre drogas, porém o viés proibicionista continuou a permear as normativas. De acordo com Alves, "uma importante mudança referese à distinção feita entre as atividades entre drogas e aquelas de prevenção, tratamento e reinserção social, conferindo maior destaque a estas últimas" (2009, p. 2315).

De fato, a III Conferência Nacional de Saúde Mental, ocorrida em 2001, conforme abordado anteriormente, foi de suma importância para esta problemática, pois traz um capítulo voltado para a atenção aos usuários de álcool e outras drogas. O relatório final da conferência declara:

\begin{abstract}
Na construção da política de saúde mental é fundamental garantir que o Ministério da Saúde defina políticas públicas de atenção aos usuários de álcool e outras drogas que deverão ser baseadas no respeito aos direitos humanos, nos princípios e diretrizes do SUS e da Reforma Psiquiátrica. É fundamental, também, garantir que o SUS se responsabilize pelo atendimento dos usuários de álcool e drogas e, ao mesmo tempo, não reduzir esta questão a uma problemática exclusiva da saúde (Sistema Único de Saúde, 2002, p. 60).
\end{abstract}

A Lei ํo. 10.409/02 dispõe sobre a prevenção, o tratamento, a fiscalização, o controle e a repressão à produção, ao uso e ao tráfico ilícitos de produtos, substâncias ou drogas ilícitas que causem dependência física ou psíquica, assim elencados pelo Ministério da Saúde, e dá outras providências. Sendo assim, destacam-se dois parágrafos do art. 12 como grandes avanços: o $§ 1 \%$. - $\mathrm{O}$ tratamento do dependente ou do usuário será feito de forma multiprofissional e, sempre que possível, com a assistência de sua família", verifica-se um tratamento realizado por diferentes profissionais e a parceria da família. E o $§ 2^{\circ}$. - "Cabe ao Ministério da Saúde regulamentar as ações que visem à redução dos danos sociais e à saúde", conforme Alves (2009), pela primeira vez na legislação brasileira sobre drogas há a referência às ações de redução de danos sociais e à saúde. 
Logo em seguida, a Política Nacional Antidrogas ${ }^{25}$ foi instituída pelo Decreto $n^{\circ}$. 4.345/02. Todavia, como o próprio nome designa "antidrogas", retrata o uso indevido de drogas como "ameaça à humanidade e à estabilidade das estruturas e valores políticos, econômicos, sociais - e culturais de todos os Estados e sociedades" (Brasil, 2002, p. 07). Acrescenta-se que a abstinência e o proibicionismo são as marcas dessa política, já que a mesma possui como primeiro pressuposto: "Buscar, incessantemente, atingir o ideal de construção de uma sociedade livre do uso de drogas ilícitas e do uso indevido de drogas lícitas" (Brasil, 2002, p. 10).

Em 2003, o Ministério da Saúde formula a Política para Atenção Integral a Usuários de Álcool e outras Drogas. Na apresentação da política pode-se perceber que se admite um atraso da temática na agenda da saúde pública:

\begin{abstract}
A ausência de cuidados que atinge, de forma histórica e contínua, aqueles que sofrem de exclusão desigual pelos serviços de saúde, aponta para a necessidade da reversão de modelos assistenciais que não contemplem as reais necessidades de uma população, o que implica em disposição para atender igualmente ao direito de cada cidadão. Tal lógica também deve ser contemplada pelo planejamento de ações voltadas para a atenção integral às pessoas que consomem álcool e outras drogas (Brasil, 2003, p. 05).
\end{abstract}

Essa afirmativa remete-nos ao público alvo do presente estudo, que são mulheres empobrecidas, criminalizadas e com dificuldades de acesso aos serviços de saúde. Além disso, ressalta-se a crítica à padronização de tratamentos que não levam em consideração as reais necessidades e vontades de cada paciente. Tais questões serão retomadas posteriormente.

Outro tópico relevante dessa lei é a questão da intersetorialidade, conceituação essencial para o desenvolvimento do trabalho em rede, por isso será realizada uma discussão mais aprofundada a seguir. Ressalta-se a presença de uma rede de responsabilidade do SUS, já que, até então, os equipamentos eram predominantemente não governamentais, como por exemplo, instituições religiosas. Apontamos abaixo alguns aspectos particularmente pertinentes para o caso das mulheres em foco nessa dissertação:

\footnotetext{
25 http://bvsms.saude.gov.br/bvs/publicacoes/PNAD_VersaoFinal.pdf. Acessado em 01/03/2015.
} 
Assim sendo, torna-se imperativa a necessidade de estruturação e fortalecimento de uma rede de assistência centrada na atenção comunitária associada à rede de serviços de saúde e sociais, que tenha ênfase na reabilitação e reinserção social dos seus usuários, sempre considerando que a oferta de cuidados a pessoas que apresentem problemas decorrentes do uso de álcool e outras drogas deve ser baseada em dispositivos extra-hospitalares de atenção psicossocial especializada, devidamente articulados à rede assistencial em saúde mental e ao restante da rede de saúde. Tais dispositivos devem fazer uso deliberado e eficaz dos conceitos de território e rede, bem como da lógica ampliada de redução de danos, realizando uma procura ativa e sistemática das necessidades a serem atendidas, de forma integrada ao meio cultural e à comunidade em que estão inseridos, e de acordo com os princípios da Reforma Psiquiátrica (Brasil, 2003, p. 05, grifos nossos).

De acordo com a SENAD (2011), em 2004 foi realizado um Seminário Internacional de Políticas Públicas sobre Drogas com seis fóruns regionais e um Fórum Nacional sobre Drogas. Nesse evento, verificou-se a necessidade de reavaliar e atualizar a Política Nacional Antidrogas. Sendo assim, em 2005, a política passou a se chamar Política Nacional sobre Drogas (PNAD) ${ }^{26}$, por meio da Resolução n. 3/GSIPR/ CONAD.

\begin{abstract}
Importantes mudanças ocorridas no cenário político da época, somadas às experiências adquiridas na implementação de programas de redução de danos na atenção a saúde de usuários de drogas injetáveis e à formulação da Política do Ministério da Saúde Para Atenção Integral a Usuários de Álcool e Outras Drogas, contribuíram para o realinhamento discursivo na política do CONAD, a começar pela denominação, que mudou de 'Antidrogas' para "Políticas sobre Drogas" (Santos e Oliveira, 2012, p. 17).
\end{abstract}

Ao realizar a leitura da nova política, observa-se uma expressiva diferença já nos pressupostos, visto que a política antidrogas trazia o termo: "sociedade livre de drogas". Enquanto isso, a nova legislação apresenta a seguinte redação: "Buscar, incessantemente, atingir o ideal de construção de uma sociedade protegida do uso de drogas ilícitas e do uso indevido de drogas lícitas" (SENAD, 2010, p. 11).

A Lei no. 11.343/06 revogou a Lei №. 6.368/76 e a Lei №. 10.409/02 e instituiu o Sistema Nacional de Políticas Públicas sobre Drogas - Sisnad; prescreve medidas para prevenção do uso indevido, atenção e reinserção social de usuários e dependentes de drogas; estabelece normas para repressão à produção não autorizada e ao tráfico ilícito de drogas; define crimes e dá outras

26 "Como resultado, o prefixo "anti" da Política Nacional Antidrogas foi substituído pelo termo "sobre", já de acordo com as tendências internacionais, com o posicionamento do governo e com a nova demanda popular, manifestada ao longo do processo de realinhamento da política" (SENAD, 2011, p. 219). 
providências $^{27}$. De certo modo, mudanças expressivas foram feitas, como a distinção entre traficante e usuário/dependente:

Para determinar se a droga destinava-se a consumo pessoal, o juiz atenderá à natureza e à quantidade da substância apreendida, ao local e às condições em que se desenvolveu a ação, às circunstâncias sociais e pessoais, bem como à conduta e aos antecedentes do agente ( $§ 2^{\circ}$. do art. 28 da Lei $n^{\circ}$. 11.343/06).

Em 2007, o Decreto no. $6.117^{28}$ aprovou a Política Nacional sobre o Álcool, a qual tem como objetivo geral:

\begin{abstract}
Estabelecer princípios que orientem a elaboração de estratégias para o enfrentamento coletivo dos problemas relacionados ao consumo de álcool, contemplando a intersetorialidade e a integralidade de ações para a redução dos danos sociais, à saúde e à vida, causados pelo consumo desta substância, bem como das situações de violência e criminalidade associadas ao uso prejudicial de bebidas alcoólicas (SENAD, 2011, p. 224).
\end{abstract}

De acordo com a SENAD (2011), o avanço da criminalidade e a sua relação com as drogas, principalmente $0 \mathrm{crack}^{29}$, levou à instituição do Decreto no. 7.17930, em 20 de maio de 2010, o qual estabeleceu o Plano Integrado de Enfrentamento ao Crack e outras Drogas. Pelo decreto, esse plano apresenta o seguinte objetivo: "prevenção do uso, ao tratamento e à reinserção social de usuários e ao enfrentamento do tráfico de crack e outras drogas ilícitas".

Diante disso, em 2011, o Ministério da Justiça lança o programa "Crack, é possível vencer"31. Esse Ministério, juntamente com outros, atua de forma integrada em três vertentes: prevenção, cuidado e autoridade. Em conformidade com as informações colhidas no site do programa, pelo eixo prevenção entendese "tudo aquilo que possa ser feito para evitar, impedir, retardar, reduzir ou minimizar o uso abusivo e os prejuízos relacionados ao consumo"; o eixo cuidado é a composição de "diversos serviços e equipamentos que oferecem ações distintas para necessidades diferentes", e o eixo autoridade é desenvolvido por duas frentes: "A primeira reúne ações de policiamento ostensivo e de proximidade (comunitário) nas áreas de concentração de uso de

\footnotetext{
27 http://www.planalto.gov.br/ccivil_03/_ato2004-2006/2006/lei/111343.htm. Acessado em 01/03/2015.

${ }^{28} \mathrm{http} / / /$ www.planalto.gov.br/ccivil_03/_ato2007-2010/2007/decreto/d6117.htm. Acessado em 01/03/2015.

${ }^{29}$ Posteriormente será apresentada a conjuntura em que seu deu a "guerra ao crack" e a intensa divulgação pela mídia e os governantes.

30http://www.planalto.gov.br/ccivil 03/Ato2007-2010/2010/Decreto/D7179.htm. Acessado em 01/03/2015.

${ }^{31} \mathrm{http} / / /$ www2.brasil.gov.br/crackepossivelvencer/home. Acessado em 01/03/2015.
} 
drogas, articuladas com saúde e assistência social. A segunda organiza ações para diminuição da presença do crack na sociedade, buscando a desconstrução da rede de narcotráfico, com atuação integrada das Polícias Federal, Rodoviária Federal, Civil e Militar no combate ao tráfico e repressão a traficantes". Pelo último eixo - autoridade - pode-se identificar a histórica política proibicionista às drogas ilícitas que permeia o Estado.

Sobre o aspecto proibicionista, Lima e Tavares (2012) afirmam que a "epidemia do crack" tornou-se objeto da agenda pública oportunizando ao Estado legitimidade para minar a liberdade e os princípios democráticos por meio de uma prática que ao mesmo tempo em que fornece uma assistência, porém de "maneira conservadora/repressiva", aprofundar a criminalização da pobreza.

No mesmo ano, a Portaria №. $3.088^{32}$ instituiu a Rede de Atenção Psicossocial para pessoas com sofrimento ou transtorno mental e com necessidades decorrentes do uso de crack, álcool e outras drogas, no âmbito do Sistema Único de Saúde (SUS). Pelo art. 1‥ identifica-se o objetivo da rede que "é a criação, ampliação e articulação de pontos de atenção à saúde para pessoas com sofrimento ou transtorno mental e com necessidades decorrentes do uso de crack, álcool e outras drogas, no âmbito do Sistema Único de Saúde (SUS)". A referida lei, seguindo a ideologia da reforma psiquiátrica, apresenta-se como importante passo para o processo de desinstitucionalização e relevância do trabalho intersetorial.

Por fim, a conjuntura histórica e legislativa apresentada mostra que alguns avanços foram realizados no âmbito da drogadição, contudo a perspectiva criminalizante, como atestam as mulheres alvo desse estudo, ainda se faz presente nas políticas públicas. Tal fato pode ser comprovando pelas ações coercitivas de combate às drogas registradas no município do Rio de Janeiro, conforme veremos a seguir.

32 http://bvsms.saude.gov.br/bvs/saudelegis/gm/2011/prt3088_23_12_2011_rep.html. Acessado em 01/03/2015. 


\section{2.}

\section{A política de drogas na cidade do Rio de Janeiro - tratamento ou punição?}

O Rio de Janeiro, a chamada "cidade maravilhosa", possui belezas naturais que são atrativos turísticos para todo o mundo. Nesse sentido, a prefeitura apresenta como uma das principais diretrizes do seu planejamento estratégico $^{33}$ a realização de obras voltadas para a captação de megaeventos mundiais, que, como consequência, atraem empreendimentos imobiliários, tornando os valores dos imóveis na cidade como um dos mais caros do mundo ${ }^{34}$.

Com essa perspectiva, a questão da segurança pública passa a ganhar lugar de destaque na agenda política municipal. Em 27 de maio de 2011, a Secretaria Municipal de Assistência Social (SMAS) ${ }^{35}$ implementou a Resolução n. ${ }^{\circ} 20$ que "cria e regulamenta o protocolo do Serviço Especializado em Abordagem Social, visando às ações de proteção social especial de média complexidade" 36 . Não se pode afirmar, mas é de grande valia se considerar que uma das motivações para a adoção desse protocolo são os grandes eventos internacionais no município do Rio de Janeiro, como os que já ocorreram Jornada Mundial da Juventude (2013) e Copa do Mundo (2014), além das Olimpíadas que acontecerão em 2016.

Diante da suposta "epidemia de crack" e sob o argumento do prover a proteção à população em situação de rua $^{37}$ e realizar tratamento para os dependentes químicos, Rodrigo Bethlen, secretário de assistência social à época, coloca em prática a resolução que tinha como uma de suas principais

33 O Plano Estratégico da Prefeitura do Rio de Janeiro (2009-2012), lançado pelo atual Prefeito Eduardo Paes é chamado de "Pós-2016 - O Rio mais integrado e competitivo". Pela leitura do plano, verifica-se que as obras são voltadas para o contexto dos megaeventos esportivos a serem realizados no Brasil, como por exemplo, o "Porto Maravilha", Transcarioca, Transoeste, Ligação C (atualmente chamada Transolímpica) e Vila Olímpica, todos ligados diretamente à produção da "Cidade Olímpica". http://www0.rio.rj.gov.br/planoestrategico/. Acessado em 04/03/2015.

${ }^{34}$ Reportagem: Ranking revela mercados de imóveis mais caros; Brasil aparece na posição 76. http://www2.uol.com.br/infopessoal/noticias/_HOME_TOP_1523212.shtml. Acessado em 04/03/2015.

${ }^{35}$ Atualmente chamada de Secretaria Municipal de Desenvolvimento Social (SMDS).

${ }^{36} \mathrm{http}: / /$ www.rio.rj.gov.br/web/guest/exibeconteudo?article-id=1811587. Acessado em 03/09/2014.

37 Pela Resolução SMAS no. 20 de 27/05/2011, são consideradas pessoas em situação de rua 0 grupo populacional heterogêneo que possui em comum a pobreza extrema, os vínculos familiares interrompidos ou fragilizados e a inexistência de moradia convencional regular, e que utiliza os logradouros públicos e as áreas degradadas como espaço de moradia e de sustento, de forma temporária ou permanente, bem como as unidades de acolhimento para pernoite ou como moradia provisória. 
ações, o chamado "Choque de Ordem"38. Este prevê recolhimento compulsório e posterior encaminhamento para instituições com a justificativa de tratamento. Essas operações são realizadas com a presença de policiais, guardas municipais e profissionais da SMAS.

Vasconcelos (2012) aponta que essa política que tem sido implantada em vários municípios, como por exemplo Rio de Janeiro e São Paulo, e tem uma perspectiva higienista na ótica da limpeza urbana nas cracolândias, as quais localizam-se próximo as regiões de valorização ou de atrações turísticas.

O Relatório de visitas aos "abrigos especializados" para crianças e adolescentes da Comissão de Defesa dos Direitos Humanos pontua que a Resolução no. 20:

(...) legitima uma política que ignora o profundo processo de exclusão social enfrentado por crianças e adolescentes em situação de rua - que convivem com a precariedade e ausência de políticas públicas como educação, saúde, habitação, e diversas formas de violações de seus direitos - e busca a solução através uma ação imediata para um fenômeno de grande complexidade (2012, p. 46).

De acordo com André Antunes na reportagem "Crack, desinformação e sensacionalismo" para o site Brasil de Fato, em 28/03/2013, o ex-ministro da saúde, Alexandre Padilha, em dezembro de 2011, no lançamento do programa 'Crack: é possível vencer' do governo federal, fez o seguinte depoimento:

Nós temos que dar para esse problema do crack um tratamento de surto epidêmico. Todo agravo à saúde que apresenta uma variação no número de casos que supera a série histórica, que muda o seu perfil regional, de localização dessa ocorrência e que ultrapassa grupos tradicionais e começa a acometer outros grupos é [considerado uma] epidemia. E esse é conceito que o Ministério da Saúde, 0 conjunto do governo e a sociedade assumem (http://www.brasildefato.com.br/node/12491. Acessado em 04/03/2015. grifos nossos).

A todo momento a mídia sensacionalista contribuía para essas medidas ao noticiar "a epidemia do crack", até mesmo antes da resolução, o que provavelmente contribuiu para a sua implementação. O site do $\mathrm{G} 1$ da emissora

\footnotetext{
${ }^{38}$ É um conjunto de ações da Secretaria Especial de Ordem Pública, criada no início de 2009 pelo atual prefeito da cidade do Rio de Janeiro, Eduardo Paes, onde a Guarda Municipal em conjunto com outros órgãos de fiscalização e limpeza como o Departamento de Transportes Rodoviários do Estado do Rio de Janeiro (Detro-RJ) e a Companhia Municipal de Limpeza Urbana (Comlurb), visa percorrer alguns bairros da cidade, recolhendo lixos, mercadorias ilegais de ambulantes, e também pessoas que morando nas rejam http://pt.wikipedia.org/wiki/Guarda_Municipal_do_Rio_de_Janeiro\#Opera.C3.A7.C3.A3o _choque_de_ordem. Acessado em 03/09/2014.
} 
"globo", em 08/06/2010, divulgou a seguinte reportagem: "Epidemia de crack está fora de controle, adverte especialista" 39 , com a seguinte fala do Sr. Pedro Lima, secretario municipal de Saúde e Defesa Civil do Rio de Janeiro à época: "O crack tem uma extensão assustadora. Existe uma sensação de descontrole, de perda da situação". Em 23/12/2014, o site R7 da emissora Record noticiou: "Epidemia do crack: Brasil é o maior consumidor de pedra do mundo"40.

Com relação à epidemia anunciada, a reportagem citada de André Antunes apresenta uma crítica ao termo amparada na reflexão do pesquisador da Escola Politécnica de Saúde Joaquim Venâncio (EPSJV/Fiocruz), Marco Aurélio Soares Jorge:

A palavra epidemia é péssima, perigosa inclusive, porque dá a ideia de uma coisa contagiosa. Vamos imaginar que eu seja usuário de crack e estou junto de você. Você vai se contagiar e começar a fumar crack? Óbvio que não, mas epidemia é assim. Acredito que falar em epidemia de crack serve até para colocar uma questão que é social como uma doença. E aí os usuários de crack passam a ser vistos como perigosos, pessoas que podem contaminar a sociedade (http://www.brasildefato.com.br/node/12491.Acessado em 04/03/201).

De fato, o II Levantamento Domiciliar sobre o Uso de Drogas Psicotrópicas no Brasil, de 2005, pesquisa do Centro Brasileiro de Informações Sobre Drogas Psicotrópicas da Universidade Federal de São Paulo (Cebrid/Unifesp) mostrou que houve um aumento do consumo de crack no país, contudo, não foi apenas dessa droga e nada de forma tão amplificada, conforme veiculado pela mídia. Entre os entrevistados das 108 cidades com mais de 200 mil habitantes, a prevalência de uso de crack no ano de 2005 foi de $0,1 \%$, enquanto a de álcool foi $49,8 \%$.

Para a SENAD (2011), atualmente, há um constante enfoque dado ao uso de crack, contudo, observa-se um aumento no consumo de álcool, uma droga que é lícita, ou seja, de fácil acesso, mas que causa tanto mal quanto as ilícitas. No caso das mulheres grávidas, o consumo excessivo de álcool pode levar à Síndrome Alcóolica Fetal (SAF), a qual acarreta comprometimento comportamental e neurológico nos recém-natos.

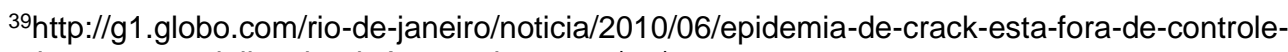
adverte -especialista.html. Acessado em 04/03/2015.

${ }^{40} \mathrm{http}: / /$ noticias.r7.com/videos/epidemia-do-crack-brasil-e-o-maior-consumidor-de-pedra-domundo/idmedia/5498bd5c0cf26089403bb4f5.html. Acessado em 04/03/2014.
} 
Em 2013, uma pesquisa encomendada pela Secretaria Nacional de Políticas Sobre Drogas à Fiocruz, considerada a Maior pesquisa sobre crack já feita no mundo, mostrou o perfil do consumo no Brasil. O estudo chamado de "Estimativa do número de usuários de crack e/ou similares nas capitais do país" divulgado pelos ministérios da Justiça e da Saúde, afirmou que:

Os usuários regulares de crack e/ou de formas similares de cocaína fumada (pasta-base, merla e oxi) somam 370 mil pessoas nas 26 capitais brasileiras e no Distrito Federal. Considerada uma população oculta e de difícil acesso, ela representa $35 \%$ do total de consumidores de drogas ilícitas, com exceção da maconha, nesses municípios, estimado em 1 milhão de brasileiros (http://portal.fiocruz.br/pt-br/content/maior-pesquisa-sobre-crack-j\%C3\%A1-feitano-mundo-mostra-o-perfil-do-consumo-no-brasil. Acessado em 04/09/2015).

Assim, o número de usuários que consomem crack e/ou similares de forma regular é na proporção de, aproximadamente, 0,81\%, apesar de ser um número expressivo que mostra a necessidade de políticas públicas voltadas para essa população, desmistifica a ideia da "epidemia do crack". Neste sentido, o repórter André Antunes ainda apresenta o questionamento do professor da Faculdade de Medicina da Universidade Federal da Bahia (UFBA), Tarcísio Andrade, sobre o excesso de atenção ao crack em detrimento a outras drogas, além do "terror ao crack" realizado pelos governantes e a mídia:

Temos um problema com o uso de crack? Temos, mas ele não tem a dimensão que está posta. Por consequência dessa amplificação, desse pânico social, acabase fazendo um diagnóstico errado e tomam-se medidas supostamente terapêuticas também equivocadas (http://www.brasildefato.com.br/node/12491. Acessado em 04/03/2015).

Para Vasconcelos (2012), esse apelo da mídia inclinado aos interesses dos setores de segurança e da psiquiatria biomédica propicia um fortalecimento dos serviços de internação não apenas em unidades psiquiátricas, como também nas comunidades terapêuticas, as quais são "implantadas por igrejas cristãs, a maioria delas evangélicas, cuja intervenção pode durar vários meses, em regime fechado" (2012, p. 174). O autor ainda cita que essas comunidades têm sido alvo de denúncias em virtude da "ausência de condições hoteleiras e sanitárias adequadas, maus tratos, isolamento e uso de celas fortes, violência, proselitismo religioso e prática obrigatória de seus rituais etc." (2012, p. 174).

No âmbito municipal, os usuários são recolhidos e alguns encaminhados para a instituição Rio Acolhedor. Esse equipamento é localizado em Paciência, 
na Zona Oeste, local de difícil acesso, no entorno da favela de Antares, onde constantemente se ouvem tiros, presenciam-se assaltos e uso abusivo de drogas, fatos esses que pude presenciar em um período curto da minha trajetória profissional. Percebe-se de imediato que a localização do abrigo impossibilita qualquer tipo de "tratamento digno", já que a poucos metros localizam-se pontos de venda de drogas. Vasconcelos (2012) afirma que grande parte desses abrigos não realiza uma atenção especializada às crianças com dependência ao crack, apenas um tratamento voltado à lógica da abstinência, reduzido à constante sedação.

Esse lugar foi considerado impróprio pelo Ministério Público do Estado do Rio de Janeiro em virtude das seguintes denúncias: "a infestação de percevejo nos colchões, estruturas precárias, insalubridade e alimentação de qualidade duvidosa", conforme reportagem do jornal O Dia, de 07/08/201441. Todavia, infelizmente, a Prefeitura do Rio logrou êxito em derrubar a liminar que impedia que moradores de rua fossem levados para o abrigo.

Para análise dessa forma de recolhimento forçado, as reflexões de Foucault em sua obra "Vigiar e Punir" são pertinentes, sobretudo quando o mesmo conceitua "poder disciplinar", que para o autor é "um poder que, em vez de apropriar e de retirar, tem como função maior "adestrar" para retirar ainda mais e melhor" (2013, p. 164), Significa dizer que essas instituições de "acolhimento" são espaços que, controlados pela equipe técnica, criam mecanismos de exercício de poder, funcionando como um mecanismo penal.

Para o CEDECA (Centro de Defesa dos Direitos da Criança e do Adolescente), as unidades de acolhimento da prefeitura do Rio de Janeiro são pauperizados, as instalações parecem antigas prisões, e os profissionais não recebem capacitação, além de não receberem benefícios trabalhistas.

Cabe destacar que, por meio da internação compulsória cria-se um modelo único de tratamento, que desrespeita as singularidades de cada usuário, fortalece a ideologia institucionalizante, excludente e de higienização ${ }^{42}$ e

\footnotetext{
${ }^{41} \mathrm{http}$ ://odia.ig.com.br/noticia/rio-de-janeiro/2014-08-07/abrigo-improprio-em-paciencia-rioacolhedor -e-liberado-pela-justica.html. Acessado em 13/10/2014.

42 O higienismo remete-nos ao episódio da Revolta da Vacina em 1904 no Rio de Janeiro, então capital federal. Na tentativa de saneamento e higiene da cidade, várias medidas sanitárias foram feitas, dentre elas: a remoção de centenas de famílias pobres, transfigurando por completo a paisagem do centro. Essa política ficou popularmente conhecida como "bota abaixo". Além disso, a vacinação obrigatória era uma entre várias medidas que visavam disciplinar a população mais pobre, erradicando-a das áreas centrais. http://educacao.uol.com.br/disciplinas/historia-
} 
contrapõe-se à Reforma Psiquiátrica, que, como apontamos, a partir da Lei №. 10.216/01 permite a internação apenas em última instância, vide o ser art. 4: "A internação, em qualquer de suas modalidades, só será indicada quando os recursos extra-hospitalares se mostrarem insuficientes".

Observa-se que a Resolução №. 20 de 2011 é baseada numa política de cunho repressivo, com foco nas ações de segurança pública em detrimento às de saúde pública e de assistência social, atuando na regressão dos direitos humanos. Assim, essas ações intensificam a criminalização da pobreza através da penalização estatal oriunda da ideologia neoliberal conforme aponta Wacquant, pois: "pretende remediar com um 'mais Estado' policial e penitenciário o "menos Estado" econômico e social" (2001, p. 04).

Em seu livro "Punir os pobres", Wacquant (2001) faz uma abordagem sobre os desdobramentos dessa política estatal de criminalização: a primeira, menos visível, consiste em transformar os serviços sociais em instrumentos de vigilância e de controle das novas "classes perigosas"; e segundo, através da contenção repressiva dos pobres pelo recurso ao encarceramento.

Rizzini e Vale (2013) afirmam que essa resolução violou o direito de crianças e adolescentes ${ }^{43}$ ao se pautar no confinamento, com ênfase no recolhimento e na internação, como forma de cuidado. As autoras acrescentam que o "pânico ao crack" veiculado pela mídia associou a situação de rua às drogas, acarretando procedimentos autoritários por parte da segurança pública. Essa situação culminou com mobilização por parte de diversos atores.

De fato, essas ações dividiram opiniões, visto que, de um lado tínhamos o discurso da mídia, que rotula o usuário de crack como uma pessoa que "não tem mais jeito" e propaga medo ao mostrar as cracolândias ${ }^{44}$, e, do outro lado, pessoas e instituições, como, por exemplo, o Conselho Regional de Serviço

\footnotetext{
brasil/revolta-da-vacina-oswaldo-cruz-e-pereira-passos-tentam-sanear-rio.htm. Acessado em $14 / 10 / 2014$.

43 Recentemente, este contexto de violação de direitos se agravou com a aprovação da redução da maioridade penal para 16 anos. No dia 19/08/2015, a Câmara dos Deputados aprovou em segundo turno por 320 votos a favor, 152 contra e 1 abstenção, a proposta de emenda à Constituição (PEC) que reduz maioridade idade penal de 18 para 16 anos no caso de crimes de homicídio doloso, lesão corporal seguida de morte e crimes hediondos, como o estupro. In: http://g1.globo.com/politica/noticia/2015/08/camara-aprova-em-2-turno-reducao-da-maioridadepenal-para-16-anos.html. Acessado em 06/09/2015.

44 Para Vasconcelos, é nas cracolândias "onde a droga está disponível, e sendo de baixo custo, o uso é sustentado com atividades de sobrevivência básica, por serviços associados ao tráfico, ou por pequenos delitos" (2012, p. 173).
} 
Social do Rio de Janeiro (CRESS RJ), o Conselho Regional de Psicologia do Rio de Janeiro (CRP RJ) e o Ministério Público do Estado do Rio de Janeiro (MPRJ).

Essas instituições criticavam o recolhimento compulsório, além das denúncias sobre o uso de violência e as péssimas condições dos locais de abrigamento. Neste contexto de mobilização, Lima, Rocha, Vale e Fonseca (2015) dissertam que em 2012 foi criada a Frente Nacional Drogas e Direitos Humanos (FNDDH), a qual motivou o surgimento da Frente Estadual Drogas e Direitos Humanos do Rio de Janeiro (FEDDH-RJ).

Desta forma, verifica-se que a internação compulsória não é a solução para o problema da drogadição, já que é um fenômeno histórico ${ }^{45}$ e complexo que depende da atuação de vários atores envolvidos nas políticas sociais. Os governantes, com o apoio da mídia, utilizam-se desse recolhimento para "limpar" a cidade para os grandes eventos e fortalecer a especulação imobiliária vivenciada nos últimos anos na cidade do Rio de Janeiro, o que vai de encontro as conquistas, já discutidas, no âmbito da saúde mental.

Assim, em consonância com as legislações já apresentadas, sugere-se que as pessoas com o uso abusivo de drogas e em situação de rua sejam direcionadas às políticas públicas por seus equipamentos, na busca da efetivação dos seus direitos sociais. Contudo, as proibições, o descaso e as repressões que permeiam o tema tornam-se o grande desafio não apenas da sociedade brasileira, como também no plano mundial.

Neste contexto de estigmas e criminalização é que se encontram as mulheres desse estudo. A complexidade da temática sobre as drogas apresenta a necessidade de um conjunto de ações que permitam à promoção de acesso aos direitos, como forma de superação das vulnerabilidades. Assim, torna-se essencial conhecer a rede de serviços ofertada pelo território da maternidade no sentido da integralidade e humanização do atendimento a essas puérperas.

\footnotetext{
45 Para se ter ideia de como as drogas são um fenômeno antigo, segue trecho do módulo I do curso da 7ạ. edição do curso SUPERA (Sistema para detecção do uso abusivo e dependência de substâncias psicoativas: encaminhamento, intervenção breve, reinserção social e acompanhamento) realizado pela SENAD ( Secretaria Nacional de Políticas sobre Drogas): "O uso de maconha com propósitos medicinais data de 2.700 a.C. Largamente utilizada na Europa com esse propósito, durante os séculos XVIII e XIX, ela foi introduzida no Brasil pelos escravos africanos e difundida também entre os indígenas, sendo no início usada com propósitos medicinais e nas atividades recreativas, como a pesca, e nas rodas de conversa, nos finais de tarde. Nos Estados Unidos, ela já era conhecida pelos índios quando os mexicanos a levaram para aquele país" (2014, p. 18).
} 


\title{
A Rede de Atenção Psicossocial (RAPS) no trabalho desenvolvido com as puérperas usuárias de drogas da maternidade de um hospital universitário na perspectiva da convivência familiar
}

\author{
3.1. \\ A intersetorialidade e a interdisciplinaridade na Rede de Atenção \\ Psicossocial (RAPS) e a precarização enfrentada pelos trabalhadores \\ da rede
}

A discussão anteriormente travada mostrou que a Política Nacional de Saúde Mental, Álcool e outras Drogas é norteada pelas diretrizes da Reforma Psiquiátrica e da Lei № 10.216/01, as quais têm como objetivo a superação do modelo asilar por meio da garantia do atendimento integral, da promoção da autonomia e do exercício da cidadania. Para isso, é relevante a articulação da rede de cuidados nos territórios. Tal fato encontra-se evidenciado entre as deliberações da III Conferência Nacional de Saúde Mental, a qual destaca:

\begin{abstract}
Garantir que o atendimento às pessoas usuárias de álcool e outras drogas e seus familiares seja integral e humanizado, realizado por equipe multidisciplinar, na rede de serviços públicos (UBS, CS, PSF, NAPS, CAPS, hospital-dia e unidade mista para tratamento de farmacodependência, serviço ambulatorial especializado, atendimento 24 horas), de acordo com a realidade local (Ministério da Saúde, 2002 , p. 61 , grifos nossos).
\end{abstract}

Essa rede de serviços encontra seu amparo legal na Portaria MS/GM no 3.088, de 23/12/2011 que institui a Rede de Atenção Psicossocial (RAPS), a qual prevê "a criação, a ampliação e a articulação de pontos de atenção à saúde para pessoas com sofrimento ou transtorno mental e com necessidades decorrentes do uso de crack, álcool e outras drogas no âmbito do SUS".

A rede de atenção psicossocial tem como objetivos gerais:

Art. $3^{\circ}$. I I - ampliar o acesso à atenção psicossocial da população em geral; II - promover o acesso das pessoas com transtornos mentais e com necessidades decorrentes do uso de crack, álcool e outrasdrogas e suas famílias aos pontos de atenção; $\mathrm{e}$

III - garantir a articulação e integração dos pontos de atenção das redes de saúde no território, qualificando o cuidado por meio do acolhimento, do acompanhamento contínuo e da atenção às urgências (grifos nossos). 
E como alguns dos objetivos específicos que permeiam o universo do público alvo do presente estudo:

\begin{abstract}
Ar. 4․: I - promover cuidados em saúde especialmente para grupos mais vulneráveis (criança, adolescente, jovens, pessoas em situação de rua e populações indígenas);

II - prevenir o consumo e a dependência de crack, álcool e outras drogas;

III - reduzir danos provocados pelo consumo de crack, álcool e outras drogas;

IV - promover a reabilitação e a reinserção das pessoas com transtorno mental e com necessidades decorrentes do uso de crack, álcool e outras drogas na sociedade, por meio do acesso ao trabalho, renda e moradia solidária; (grifos nossos).
\end{abstract}

Para Assis et al. (2014), a RAPS possui duas dimensões: a normativoinstitucional e a operacional, a qual depende das relações efetivas entre pessoas. Esses autores também trazem que, em conformidade com a lei noํ. 10.216/01, a RAPS deve realizar práticas efetivas em substituição ao modelo asilar, ou seja, "assumir a responsabilidade pela saúde mental de um determinado território e desenvolver a RAPS de modo a desconstruir na prática a necessidade de manicômios" (2014, p. 92).

Como a proposta é a identificação dos serviços da rede de atenção psicossocial para o trabalho desenvolvido com as puérperas usuárias de drogas da maternidade de um hospital universitário, para conceituação de rede será utilizada a definição de Couto (2012):

(...) por lógica de rede entende-se a organização não hierárquica de serviços situados em um território sanitário, articulados por objetivos comuns, pelo uso compartilhado de tecnologias e recursos, por ações colaborativas e corresponsáveis, que permitem ofertar atenção contínua e integral a determinada população, gerando valor para os usuários do sistema de saúde (2012, p. 106).

Ainda na conjuntura da temática de rede, a autora supracitada apresenta a noção de Rede Pública Ampliada a partir de alguns fundamentos da ação psicossocial, que consideramos pertinente exemplificar: "responsabilidade pública, base comunitária, clínica ampliada, trabalho em equipe multiprofissional, intersetorialidade, e reconhecimento do usuário como sujeito psíquico, ativo em sua história e experiência de vida" (Couto, 2012, p. 100).

A partir da lógica de Rede Pública Ampliada e objetivando o bom desempenho dos equipamentos que a compõe, entende-se que no presente 
estudo é fundamental discutir as noções de intersetorialidade e de interdisciplinaridade.

A intersetorialidade é um termo que vem se demonstrando importante para o desenvolvimento das políticas públicas. A seguir destacaremos alguns dos elementos que vêm contribuindo para o seu desenvolvimento na prática. No âmbito da drogadição, a articulação entre os setores se faz presente em diversas legislações, como por exemplo, no Decreto no. 6.117/07:

A Política Nacional sobre o Álcool contém princípios fundamentais à sustentação de estratégias para o enfrentamento coletivo dos problemas relacionados ao consumo de álcool, contemplando a intersetorialidade e a integralidade de ações para a redução dos danos sociais, à saúde e à vida causados pelo consumo desta substância, bem como as situações de violência e criminalidade associadas ao uso prejudicial de bebidas alcoólicas na população brasileira (Objetivo do Decreto №. 6.117/07).

A intersetorialidade é também uma das diretrizes da Política do Ministério da Saúde para a Atenção Integral a Usuários de Álcool e outras Drogas:

\begin{abstract}
O uso de álcool e outras drogas, por tratar-se de um tema transversal a outras áreas da saúde, da justiça, da educação, social e de desenvolvimento, requer uma intensa capilaridade para a execução de uma política de atenção integral ao consumidor de álcool e outras drogas. As articulações com a sociedade civil, movimentos sindicais, associações e organizações comunitárias e universidades, são fundamentais para a elaboração de planos estratégicos dos estados e municípios, ampliando-se significativamente a cobertura das ações dirigidas a populações de difícil acesso. Tais articulações constituem-se em instrumentos fundamentais de defesa e promocão de direitos (advocacy) e de controle social. Nesse sentido, no campo da prática de políticas públicas, a intersetorialidade e a intrasetorialidade ${ }^{46}$ requerem investimentos contínuos e de longo prazo, dedicando esforços coerentes a cada nova geração (Brasil, 2003, p. 28, grifos nossos).
\end{abstract}

Segundo Nascimento, "a intersetorialidade passou a ser um dos requisitos para a implementação das políticas setoriais, visando à sua efetividade por meio da articulação entre instituições governamentais e entre essas e a sociedade civil" (2010, p. 96) e acrescenta que a intersetorialidade colabora para a construção de saberes a partir da integração entre os setores.

Inojosa define a intersetorialidade como "a articulação de saberes e experiências para o planejamento, a realização de avaliação de políticas, programas e projetos, cujo fim é alcançar resultados cooperativos em situações

\footnotetext{
46 De acordo com o dicionário o prefixo "intra" exprime a noção de dentro de. Logo, a palavra intrasetorialidade é compreendida pela relação ocorrida dentro de um setor. http://www.priberam.pt/dlpo/intra-. Acessado em 06/03/2015.
} 
complexas" (2001, p. 43) e, ainda, Tumelero (2011) compreende como um trabalho em rede destinado aos vulneráveis numa perspectiva de relações horizontalizadas.

Acrescenta-se Feuerwerker e Costa (2000) apud Azevedo, Pelicioni e Westphal (2012)

(...) a articulação entre sujeitos de setores diversos e, portanto, de saberes, poderes e vontades diversos, para enfrentar problemas complexos. É uma nova forma de trabalhar, de governar e de construir políticas públicas que pretende possibilitar a superação da fragmentação dos conhecimentos e das estruturais sociais para produzir efeitos mais significativos na saúde da população (2012, p. 1334).

Para Monnerat e Souza (2011), a intersetorialidade direciona-se para a solução de problemas sociais complexos que necessitem da interlocução demais de um setor, tanto governamentais quanto não governamentais.

No âmbito da saúde, as autoras supracitadas pontuam que o conceito de intersetorialidade foi incorporado pela lei no. 8.080/90 e tem sido tratada como uma estratégia fundamental para atuar nos problemas societários que incidem no binômio saúde-doença. Contudo, as autoras apontam que, dentre as diretrizes da lei citada, a integralidade ${ }^{47}$ foi a que menos se desenvolveu, por isso a intersetorialidade é um grande desafio para o SUS. Tal fato torna-se muito preocupante, visto que para as autoras para a efetivação da política de saúde, há a necessidade do envolvimento de outros atores.

Sob o ângulo da assistência social e com o enfoque da conjuntura das drogas, a intersetorialidade se propõe por meio de um trabalho em rede na perspectiva da proteção social, conforme a Política Nacional de Assistência Social (PNAS) por meio do Sistema Único de Assistência Social (SUAS), que tem como um dos princípios organizativos:

\begin{abstract}
articulação intersetorial de competências e ações entre o SUAS e o Sistema Único de Saúde - SUS, por intermédio da rede de serviços complementares para desenvolver ações de acolhida, cuidados e proteções como parte da política de proteção às vítimas de danos, drogadição, violência familiar e sexual, deficiência, fragilidades pessoais e problemas de saúde mental, abandono em qualquer momento do ciclo devida, associados a vulnerabilidades pessoais, familiares e por ausência temporal ou permanente de autonomia principalmente nas situações de drogadição e, em particular, os drogaditos nas ruas (grifos nossos).
\end{abstract}

\footnotetext{
47 Inciso II do art. 7ํ․ Da Lei nํ. 8.080/90: "integralidade de assistência, entendida como conjunto articulado e contínuo das ações e serviços preventivos e curativos, individuais e coletivos, exigidos para cada caso em todos os níveis de complexidade do sistema".
} 
Dessa maneira, a intersetorialidade potencializa as políticas públicas, pois faz com que os equipamentos realizem os seus serviços de forma conjunta, promovendo a articulação de saberes, objetivando o fornecimento de subsídios para que se possam superar as vulnerabilidades que incidem nas famílias. Nesse sentido, articulando o significado de rede com o de intersetorialidade, Rizzini, Rizzini, Naif e Batista consideram que "o trabalho em rede não visa somente à otimização dos esforços, mas à valorização do contexto de vida do sujeito, priorizando o atendimento pelas instituições e pessoas inseridas no seu meio social" (2006, p. 114). Acrescenta-se, consoante Menicucci, 2002 apud Silva e Barroso, que a formação de redes:

Ganha proeminência na perspectiva da intersetorialidade, princípio de acordo com o qual a necessidade de estabelecer vínculos, relações entre organizações, mediadas por atores, se justifica pela necessidade de entender de maneira compartilhada a realidade social $(2007$, p. 06$)$.

Há, contudo, uma grande distância entre as diretrizes apontadas e o que ocorre na prática, como entraves ao funcionamento em rede, Tumelero (2011) aponta a burocratização e a fragmentação entre as ações. Assim, o debate da intersetorialidade surge como uma estratégia e um grande desafio para a construção de ações complementares e integradas em um momento marcado pela fragmentação do setor público.

Além da afinidade com a noção de rede, a intersetorialidade dialoga com a interdisciplinaridade, um outro conceito de suma importância para o tratamento não só das drogas, como também de outras questões que permeiam a prática profissional cotidiana, visto que é fundamental que ocorra uma troca entre os saberes e o abandono de posturas centralizadoras.

Há várias formas de diálogos entre os saberes (disciplinas) como a transdisciplinaridade, a pluridisciplinaridade e a multidisciplinaridade, além da interdisciplinaridade. Focalizaremos brevemente esses conceitos, sugerindo-se 0 que melhor parece se adequar ao presente estudo

Para Aiub, 2006 apud Galván, 2007, a transdisciplinaridade tem "olhar para a dimensão do universo e a compreensão da impossibilidade de abarcá-lo no âmbito de alguma disciplina, seja ela qual for $\mathrm{e}$ independentemente da profundidade com que possa ser conhecida" (2007, p. 56), havendo a possibilidade de ter perguntas sem respostas. Segundo Silva e Mendes: "referese a um estágio mais profundo de interação entre as áreas do conhecimento, 
levando à constituição de um campo autônomo de saber e intervenção, a partir das diferentes disciplinas que o compõem" (2013, p.55).

A pluridisciplinaridade, na visão de Silva e Mendes: "refere-se ao efetivo relacionamento entre as disciplinas, sob a coordenação da direção de uma instituição ou de uma das áreas" (2013, p. 55).

Enquanto isso, Almeida Filho, 2005 apud Galván, 2007 diz que a multidisciplinaridade é "como um conjunto de disciplinas que trata, simultaneamente, de uma dada questão, sem que os profissionais implicados estabeleçam efetivas trocas entre si" (2007, p. 55) e complementando pela noção de Silva e Mendes, é um "processo de trabalho que se dá de forma isolada, sem um compromisso maior com a troca de conhecimentos e a cooperação entre as diferentes áreas" (2013, p. 55). Dessa maneira, observa-se que não há um diálogo numa equipe multiprofissional, mas sim um grupo de pessoas de áreas distintas ocupando o mesmo espaço.

Optou-se por trabalhar com a interdisciplinaridade, em virtude de o seu prefixo "inter" já trazer a ideia de reciprocidade, troca, diálogo, que são de suma importância para a atuação na temática proposta. Para Vasconcelos, 1997 apud Ely, 2003, a interdisciplinaridade é entendida como "as relações profissionais e de poder tendem à horizontalidade, as estratégias de ação são comuns e estabelece-se uma troca recíproca de conhecimento entre as diferentes disciplinas" (2003, p. 114).

Silva e Mendes (2013) afirmam que a prática interdisciplinar possibilita a superação de uma atuação fragmentada e individualizada na esfera da saúde, permitindo o desenvolvimento de ações profissionais que preservem a autonomia do saber ao mesmo tempo em que socializa conhecimentos pelas equipes de saúde.

Entretanto, a interdisciplinaridade é um grande desafio na construção das práticas integrais para a saúde, pelo fato de que, segundo Silva e Mendes, esse conceito é visto como "algo que vai muito além da inserção de profissionais de diversas áreas do conhecimento nas instituições de saúde" (2013, p. 50), pois percebe-se que grande parte dos profissionais não recebeu uma formação voltada para ações de troca e complementação de saberes, ou seja, a presença de uma equipe multiprofissional não significa existência de uma prática 
interdisciplinar, devendo ocorrer por meio de estudos de caso, reuniões de equipes, enfim, práticas que promovam uma interlocução.

Não obstante, Vallim (2012) destaca que, em um estudo realizado pelo Instituto de Psiquiatria da Universidade Federal do Rio de Janeiro (UFRJ) sobre a capacitação dos profissionais voltados para o atendimento aos usuários de drogas, concluiu-se que os mesmos não se consideram preparados para essa função: "a formação acadêmica para a assistência a usuários de drogas é considerada insuficiente pelos médicos entrevistados" (Cruz e Silva Filho, 2005 apud Vallim, 2012, p. 15). Dessa maneira, a pesquisa recomenda às instituições para que realizem capacitações contínuas com seus profissionais, numa perspectiva de formação crítica com potencial para intervir na realidade.

De fato, um olhar interdisciplinar e intersetorial necessita ser compreendido como um dos pilares das políticas públicas, ou seja, é importante ter a clareza de que é muito difícil que um único setor ou apenas uma profissão dê conta da problemática do uso abusivo de drogas. O caráter fragmentado e descontínuo das políticas públicas, sobretudo no atual contexto neoliberal, conforme já apontado, acarreta a dificuldade de operacionalização dos serviços da rede. Bisneto faz a seguinte reflexão no âmbito da saúde mental:

(...) com a hegemonia das políticas neoliberais, que trazem em seu bojo uma desvalorização do trabalho humano, uma falta de solidariedade para com os excluídos, um desmonte das políticas sociais, uma conjuntura de nãodemocratização (entre outros inúmeros fatores), o Movimento de Reforma Psiquiátrica tem sofrido reveses na continuidade de suas propostas, dentre elas a diminuição do investimento público no setor de Saúde Mental (Bisneto, 2011, p. 42).

Este aspecto foi debatido no Seminário "Privatizações, desmonte da Rede de Saúde Mental e Retrocesso na Reforma Psiquiátrica: Como nos organizar para resistir?"48 (2014) organizado pelo Fórum de Trabalhadores Saúde Mental do Rio. Uma das conclusões indicadas foi que a Rede de Saúde Mental do Rio de Janeiro encontrava-se num processo de desmonte, agravado em 2014 a partir da entrada das Organizações Sociais (OSs) ${ }^{49}$.

\footnotetext{
48 Seminário do qual participei em 14 de março de 2015 na Universidade do Estado do Rio de Janeiro (UERJ).

49 De acordo com Bravo: "As Organizações Sociais (OS) e as Organizações da Sociedade Civil de Interesse Público (Oscip) pretendem transformar a gestão pública e surgem nos anos 1990 por meio da chamada Reforma do Estado do governo FHC que teve como protagonista Bresser Pereira" (2011, p. 186).
} 
Essa situação foi relatada na reportagem "Saúde mental do Rio de Janeiro - Privatização e retrocesso na reforma antipsiquiátrica" ${ }^{50}$ do Setorial de Saúde do Site Liberdade, Socialismo e Revolução, publicada em 12 de maio de 2015, quando situa que: "Está ocorrendo um desmonte da rede de saúde mental, intensificado com a entrada das OSs (Organizações Sociais), que terceirizam a gestão dos serviços, através de uma lógica mercadológica" e acrescenta que "na saúde mental do Rio de Janeiro está se implementando o modelo clássico da privatização, sucateando o público para justificar a entrada da iniciativa privada".

Franco (1998) realiza uma análise sobre as Organizações Sociais mostrando as suas contraposições ao SUS constitucional ao pontuar que extingue o quadro de servidores públicos, além de conceder o encargo da saúde para o mercado, deixando de ser um direito público.

Em outras palavras, por meio dessas Organizações Sociais, o projeto neoliberal calca-se num discurso de contenção de despesas com a saúde pública. Para Bisneto (2011), esse processo tem como consequências uma redução no quantitativo de atendimentos, transferência de responsabilidade para o âmbito privado, na lógica do lucro, e também a concessão de serviços essenciais mínimos às camadas pauperizadas.

Um outro tópico bastante discutido no seminário foi a fragilização dos direitos trabalhistas, principalmente com a redução dos concursos públicos para que haja cada vez menos profissionais com vínculos estatutários. Diante disso, Bisneto afirma que "os trabalhadores da saúde mental estão sendo prejudicados pelo desemprego, terceirização e precarização, instabilidade no emprego etc. também em função da reestruturação produtiva que atinge até os serviços" (2011, p. 44).

Os efeitos do retrocesso da reforma psiquiátrica trazem outras implicações para o funcionamento dos equipamentos da saúde mental, como a falta de profissionais de algumas especialidades, estrutura física precária, falta de medicamentos, burocracia para a obtenção dos benefícios sociais como o vale social e o Benefício de Prestação Continuada (BPC), a constante rotatividade de profissionais, o que dificulta a criação de um vínculo com o paciente. Esses entre outros aspectos não prejudicam apenas os trabalhadores da saúde mental, como também os das outras áreas que necessitam dessa rede para

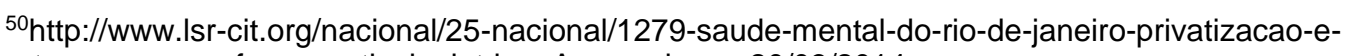
retrocesso-na-reforma-antipsiquiatrica. Acessado em 20/03/2014. 
encaminhamentos e, principalmente, os usuários e seus familiares, os quais se encontram negligenciados por uma política essencialmente de interesses econômicos e excludentes.

Esse contexto mostra que, cada vez mais os trabalhadores das redes de serviço e seus usuários precisam se unir para criar estratégias de resgate e fortalecimento das conquistas das reformas sanitária e psiquiátrica contra a política do desmonte e da privatização.

Enfim, adiciona-se que, nos moldes do que já foi explicitado, o usuário não sofre sozinho com a problemática das drogas, mas também a família e, portanto, ambos precisam de apoio e cuidado. Assim, a família torna-se usuária dos serviços ao mesmo tempo em que participa do processo de cuidado. Com isso, os dispositivos da rede devem, de forma articulada, garantir a integralidade da atenção e a intersetorialidade das políticas públicas na perspectiva da convivência familiar.

Para isso, o presente estudo tem como proposta o conhecimento da Rede de Atenção Psicossocial a fim de que os profissionais envolvidos no atendimento às puérperas com uso abusivo de drogas possam trabalhar no viés da totalidade das respostas às suas demandas.

\section{2.}

A identificação dos serviços da Rede de atenção psicossocial (RAPS) no território de um hospital universitário e a sua contribuição no atendimento às puérperas com "uso problemático de drogas" na perspectiva da convivência familiar

Pelo cenário exposto, identifica-se que os serviços públicos, não apenas os de saúde mental, mas os da saúde como um todo, tendenciam perversamente à privatização e à redução das iniciativas do Estado, trazendo desafios para o desenvolvimento de ações efetivas na promoção, na proteção e na defesa de direitos. Tendo como local de estudo, um Hospital Universitário (HU) localizado na zona norte do município do Rio de Janeiro, verifica-se que a saúde pública, universal e de qualidade é constantemente "atacada" pelo avanço do projeto privatista, tal como reflete Vasconcelos: "Evidencia-se na década de 90 a hegemonia do projeto privatista na saúde, com a hegemonia dos seguros 
privados e o projeto contra hegemônico com base na Reforma Sanitária" (2007, p.86).

Uma das lutas enfrentadas pelos hospitais universitários é a forte imposição da privatização por meio da EBSERH (Empresa Brasileira de Serviços Hospitalares) $)^{51}$, sob a alegação de que não há dinheiro público para a manutenção dos serviços. Igualmente ao que ocorre nos equipamentos da rede de saúde mental, as constantes demissões e a suspensão dos serviços são utilizadas como armas para pressionar a implantação da EBSERH. Com relação aos vínculos empregatícios, a supracitada empresa objetiva precarizá-los ao determinar o fim do RJU (Regime Jurídico Único) por meio da substituição da estabilidade por contratos celetistas e temporários.

Vasconcelos aponta, ainda, que a transferência dos hospitais universitários e das unidades públicas de saúde em organizações sociais "coloca o Estado como provedor, mas o exime da responsabilidade não só de prover tais serviços, como também, principalmente, de imprimir uma política reguladora da prestação destes serviços" (2007, p. 92).

Mesmo com todos os entraves apresentados, considera-se importante que, a partir da noção de que o "processo de saúde-adoecimento está intimamente relacionado a múltiplos determinantes sociais" (BRASIL, 2014, p. 21), os profissionais desenvolvam estratégias para a promoção da saúde por meio do fortalecimento da rede de serviços.

Com relação ao nosso público-alvo, que são as puérperas usuárias de drogas, conforme já mencionado, quando chegam ao hospital, geralmente não realizam pré-natal, estão com vínculos familiares fragilizados ou rompidos, não possuem documentação civil, além de não fazerem tratamento especializado para drogas etc. Ressalta-se que, em muitas das vezes, a hora do parto é o primeiro acesso ao serviço de saúde dessas gestantes. Nessa conjuntura, alguns pontos serão considerados de maneira a contribuir para um atendimento integral a essas mães.

\footnotetext{
${ }^{51}$ A Empresa Brasileira de Serviços Hospitalares (EBSERH) é uma empresa pública de direito privado, criada pela Lei Federal no 12.550 , de 15 de dezembro de 2011 com estatuto social aprovado pelo Decreto o 7.661, de 28 de dezembro de 2011. http://portal.mec.gov.br/index.php? option=com_content\&view=article\&id=17829\&Itemid=1187. Acessado em 15/10/2014.
} 


\section{Judicialização}

Um dos pontos mais expressivos em relação ao desafio profissional tem sido a garantia da convivência familiar, categoria que será analisada posteriormente, já que em muitos casos, as puérperas encontram-se em situação de rua em virtude da frágil rede de suporte institucional e/ou familiar. Com isso, a possibilidade de destituição do poder familiar é frequente a partir do encaminhamento ao Judiciário, fluxo por ora estabelecido, ocasionando às puérperas mais uma violação de direitos ao romper o vínculo entre elas e os seus bebês.

A respeito disso, Oliveira (2014) cita que o carecimento de políticas públicas que atuam na resolução da procedência dos conflitos cotidianos faz com que a sociedade recorra constantemente ao Judiciário, contribuindo para o "processo de judicialização das relações sociais". Oliveira se utiliza dos autores Santos e Rifiotis (2006) para caracterizar essa judicialização:

(...) se caracteriza por uma espécie de invasão do direito - como campo de saber e de práticas - na organização da vida social contemporânea, incidindo sobre a regulação da esfera política, da sociabilidade e das políticas sociais. Se por um lado resulta em ampliação do acesso ao sistema Judiciário, por outro termina por desvalorizar formas alternativas de resolução de conflitos. (Oliveira, 2014, p. 9)

Barison (2014) aponta que o Judiciário tem se tornado um protagonista no enfrentamento da questão social a partir do momento em que sua interseção efetiva as políticas sociais. Dessa maneira, busca-se o Judiciário quando os recursos, principalmente do executivo forem esgotados. Neste sentido, Barison faz a seguinte reflexão:

(...) é acionar mecanismos conservadores na medida em que desconsidera os conflitos de classes que elas expressam, visto que passam a ser compreendidas como problemas individuais e não como manifestações das relações sociais inscritas na coletividade. (Barison, 2014, p. 27)

Para Aguinsky e Alencastro (2006) nem sempre o que é legal, normatizado, é justo. Acrescentam que o Poder Judiciário "não terá resposta milagrosa" (2006, p. 24) para a ausência de ações do Estado junto à luta contra a desigualdade social. Observa-se que a judicialização é um tema polêmico pois cada vez mais a ampliação do protagonismo Judiciário nos conflitos do cotidiano aumenta o seu controle nas relações sociais e, por consequência, reduz 
conquistas coletivas ao âmbito meramente individual, quando se decide caso a caso.

Nos relatórios ${ }^{52}$ de encaminhamentos realizados pelo hospital universitário em questão, verifiquei que há um constante envio dos casos para o Conselho Tutelar e para a Vara da Infância Juventude e Idoso. Em 2013, dos 05 casos, 04 foram encaminhados para o Conselho Tutelar e 01 para a Vara da Infância. Em 2014, dos 06 casos, apenas 01 foi encaminhado para o Conselho, o restante foi para a Vara. Tal fato ocorreu porque durante as oficinas de debate, o Conselho Tutelar se posicionou alegando que não estavam conseguindo "dar conta da demanda" com a estrutura que possuem.

A partir disso, faz-se necessário definir as instituições utilizadas nos encaminhamentos citados. De acordo com o Estatuto da Criança e do Adolescente "Art. 131. O Conselho Tutelar é órgão permanente e autônomo, não jurisdicional, encarregado pela sociedade de zelar pelo cumprimento dos direitos da criança e do adolescente, definidos nesta Lei". Os casos que foram enviados para o Conselho eram situações em que as puérperas tinham vínculos familiares que necessitavam de um acompanhamento, orientação e apoio.

Enquanto isso, segundo o regimento interno da $1^{\text {a }}$ Vara da Infância e da Juventude da Capital do Estado do Rio de Janeiro, atualmente, também do Idoso, possui a seguinte finalidade "garantir os interesses superiores da criança e do adolescente através do desempenho da competência e das atribuições definidas no Estatuto da Criança e do Adolescente". Antes do posicionamento do Conselho Tutelar sobre a falta de estrutura, os casos encaminhados eram quando a mulher vivia em situação de rua e/ou não possuía suporte familiar.

Nos casos de encaminhamento para a Vara, percebe-se que há uma concessão de responsabilidade para o Judiciário sobre a decisão da vida das puérperas e dos recém-natos, o que mostra a limitação das outras categorias profissionais que, por meio de relatórios e pareceres, se posicionam sobre os casos, no entanto, a decisão final é delegada ao juiz.

Geralmente na prática, por esse trâmite, as crianças são institucionalizadas, e as mães retornam às drogas, possibilitando a repetição do ciclo com uma nova gravidez em precárias condições, já que não há

${ }^{52}$ Os relatórios foram cautelosamente estudados apenas com a finalidade de verificação dos encaminhamentos e não serão expostas informações mais aprofundadas por questões éticas. 
estabelecimentos dignos para o acolhimento conjunto mãe e filho para a tentativa de formação de "laços", de acordo com os debates ofertados nas oficinas "Maternidade de Jovens em Situação de Rua e/ou Usuárias de Drogas e Atenção aos seus Bebês" e com a minha experiência profissional.

É imperioso ressaltar que essas oficinas iniciaram-se no final de 2013, por iniciativa do Fórum de pessoas em situação de rua e de um grupo de assistentes sociais de maternidades, com o apoio do Conselho Regional de Serviço Social (CRESS), posteriormente, vários outros atores começaram a participar como outras maternidades do município do Rio de Janeiro, o Ministério Público do Estado do Rio de Janeiro (MPRJ), o Conselho Regional de Psicologia (CRP), entre representantes de outras instituições.

As oficinas possuem como principais focos: "análise da realidade e possível construção e articulação da rede de serviços da saúde e da assistência social para proteção da mãe e da criança, na intenção de preservar a convivência familiar e o papel das assistentes sociais nas maternidades e a necessária interlocução com as Varas da Infância e com os Conselhos Tutelares" 53 , ou seja, busca-se reduzir o constante encaminhamento para o Judiciário desses casos, pois relataram que grande parte das crianças institucionalizadas são filhos de mulheres em situação de rua e/ou usuárias de drogas.

Diante disso, a ausência de um protocolo de atendimento numa rede de serviços que atue de forma articulada para esses casos é uma grande preocupação nos debates, por isso, em diversos encontros presenciei discussões sobre a construção de um fluxo de serviços com apoio do Ministério Público e da Defensoria Pública na tentativa de manter os bebês com as suas famílias. Em um dos eventos, tivemos a apresentação de uma Instituição de Acolhimento que trouxe estatísticas que comprovavam o aumento do número de crianças institucionalizadas em decorrência do crack e uma das críticas levantadas foi o acolhimento apenas das crianças, visto que a família também possui necessidades.

Observa-se que alguns profissionais de saúde estão encaminhando para o Judiciário sem critério de avaliação, fazendo com que as puérperas usuárias

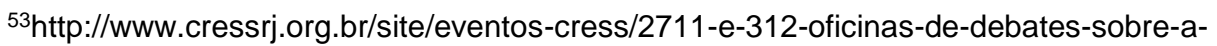
maternidade-de-jovens-em-situacao-de-rua-eou-usuarias-de-drogas-e-a-atencao-aos-seus-bebes/. Acessado em 08/04/2015.
} 
protagonizem uma violência institucionalizada ocasionada pela criminalização da pobreza. Por essas e outras questões, sugere-se, primeiramente, a oportunização a essas mães do acesso aos serviços, na tentativa de superação das fragilidades que levaram à situação de vulnerabilidade, por isso, a proposta deste estudo em conhecer a rede de atenção psicossocial.

\section{O mito da maternidade e a responsabilização "exclusiva" das mulheres}

Há casos em que a mãe deseja entregar o seu filho para a adoção por diversos motivos, como os que Gois aponta: "a falta de condições socioeconômicas da família biológica, associada à falta de apoio da família extensa, a problemas emocionais da mãe, à morte do cônjuge, à negligência $e$ maus-tratos e à violência doméstica" (2013, p. 225). É importante frisar que a entrega é um direito que a paciente possui, amparado pelo $\S 5^{\circ}$ do art. $8^{\circ}$ do Estatuto da Criança e do Adolescente, incluído pela nova lei da adoção - Lei no. 12.010/09:

Art. $8^{\circ}$ É assegurado à gestante, através do Sistema Único de Saúde, o atendimento pré e perinatal. §5o A assistência referida no $\S 4^{\circ}$ deste artigo deverá ser também prestada a gestantes ou mães que manifestem interesse em entregar seus filhos para adoção.

Para Gois (2013), o amor materno pode se dar de forma paradoxal, e a entrega à adoção seria um exemplo ao considerar que houve uma preocupação com a criança, protegendo-a de uma situação de vulnerabilidade.

Cabe destacar que esse tópico deveria ser mais debatido tanto na academia quanto no âmbito profissional, pois em minha trajetória observo ainda "um certo preconceito" em virtude do mito da maternidade como uma realização indispensável para a mulher e uma crítica muito severa às puérperas que resolvem entregar seus filhos. O não julgamento da paciente é essencial para um atendimento adequado, sobre esse aspecto, cabe uma colocação de Morgado "a qualificação contínua relaciona-se a uma postura ética para nos distanciarmos de intervenções baseadas no senso comum, possibilitando assim ultrapassar a postura de culpabilização para a de oferecer suporte profissional" (2012, p. 228). 
De fato, historicamente, a sociedade imputou a mulher "imenso valor à função materna. A mãe é considerada o pilar, emocional e afetivo, de sustentação da família" (Morgado, 2012, p. 38). Assim, consolidou-se um processo centrado no cuidado como uma vocação socialmente construída para o gênero feminino, um "atributo natural e exclusivo da mulher" (ibid., p. 138), ou ainda, "princípio máximo de realização da mulher" (ibid., p. 139), tanto que desde pequenas as mulheres são incentivadas a brincarem de bonecas como forma de um "treinamento" para o cuidado materno. Morgado (2012) afirma com base em Badinter que a responsabilidade atribuída as mulheres tem como consequência santifica-la no caso da concordância de todos, mas também, culpá-la e condenála, caso fracassasse em sua "missão sagrada" (2012, p. 151).

Sarti (2015) cita que a partir da década de 60, não apenas no Brasil, mas em âmbito mundial, houve a difusão da pílula anticoncepcional, desatrelando a sexualidade da reprodução, ou seja, da maternidade. Para a autora "a pílula abala o valor sagrado da maternidade e a identificação entre mulher e mãe, ao permitir a autonomia da sexualidade feminina sem sua inexorável associação com a reprodução" (2015, p. 32).

Na verdade, o que há é uma responsabilização exclusiva da mulher/mãe com seus filhos, haja vista que, em minha experiência profissional, dificilmente presenciei o questionamento sobre o pai ${ }^{54}$ da criança pelas equipes de saúde. Geralmente, quando há a presença do genitor, ela aparece de forma superficial na condição de "pai visitante", além disso, alguns serviços de saúde criam barreiras para uma maior participação do homem ao impedi-los de permanecerem nos leitos sob a justificativa de serem alas femininas. Contudo, a Lei no 11.108, de 7 de abril de 2005, a qual garante à parturiente um acompanhante durante todo o período de trabalho de parto, parto e pós-parto imediato não faz restrições ao sexo do acompanhante.

\footnotetext{
${ }^{54}$ As próprias leis desatrelam o pai ao cuidado, basta verificarmos a diferença de tempo que há entre as licenças maternidades e paternidades na Constituição da República Federativa do Brasil de1988: XVIII do art. 70 - "licença à gestante, sem prejuízo do emprego e do salário, com a duração de cento e vinte dias"; $\S 1^{\circ}$ do art. 10 - "Até que a lei venha a disciplinar o disposto no art. $7^{\circ}, \mathrm{XIX}$, da Constituição, o prazo da licença-paternidade a que se refere o inciso é de cinco dias".
} 


\section{Pobreza e institucionalização}

Pela minha participação nas oficinas "Maternidade de Jovens em Situação de Rua e/ou Usuárias de Drogas e Atenção aos seus Bebês" observei que as drogas têm sido um dos motivos para que as mães "pobres" sejam impedidas de sair da maternidade com seus filhos com a justificativa apenas de que elas não possuem condições de cuidar da criança. Será que isso ocorre nas maternidades em que seu público alvo são famílias abastadas?

Em maio de 2015 foi noticiado ${ }^{55}$ que, neste ano, por meio de recomendação do Ministério Público de Belo Horizonte, pelo menos 120 crianças, filhos de mães dependentes químicas, foram retiradas das maternidades para as instituições de acolhimento sob a alegação de que as genitoras não possuem condições de proporcionar o cuidado. E que tal medida tem acarretado a não realização do pré-natal por medo de perderem os bebês. Constata-se, diante desse quadro, uma violação dos direitos dessas mulheres consubstanciada pela criminalização da pobreza.

Rizzini, Rizzini, Naiff e Batista (2006) indicam que pesquisas apontam que crianças são afastadas de suas famílias por motivos de pobreza e violência e encaminhadas para instituições sob a alegação de "proteção", em detrimento de um trabalho voltado para a superação das fragilidades que acarretaram a separação.

Sobre esse aspecto, um levantamento nacional feito pelo Instituto de Pesquisa Econômica Aplicada (IPEA) em 2004 apontou que o principal motivo para que as crianças sejam abrigadas é a carência de recursos materiais da família ${ }^{56}$. Todavia, o Estatuto da Criança e do Adolescente, em seu art. 23 explicita que "falta ou a carência de recursos materiais não constitui motivo suficiente para a perda ou a suspensão do poder familiar", ou seja, não é o fato de uma família ser pobre que a torna menos apta no cuidado da sua prole.

Uma pesquisa ${ }^{57}$ mais atual da base de dados no Ministério Público do Estado do Rio de Janeiro também apresenta a ausência de recursos financeiros como uma das maiores motivações para o acolhimento. Nas palavras dos

\footnotetext{
${ }^{55} \mathrm{http} / / /$ noticias.r7.com/minas-gerais/adocao-obrigatoria-de-bebes-de-usuarias-de-drogas-provocadiscussao-em-bh-23052015. Acessado em 08/09/2015.

56 http://memoria.ebc.com.br/agenciabrasil/noticia/2010-09-18/politicas-publicas-poderiam-ajudardiminuir-acolhimento-de-criancas-e-adolescentes-em-abrigos. Acessado em 05/12/2014.

57 Censo da População infantojuvenil acolhida do Estado do Rio de Janeiro - Base 31/12/2014. http://mca.mp.rj.gov.br/wp-content/uploads/2015/01/14o_Censo_2_Censo_do_Estado.pdf. Acessado em 06/09/2015.
} 
autores Rizzini, Rizzini, Naiff e Baptista, "persiste o mito de que as crianças estariam protegidas e em melhores condições longe de suas famílias tidas como “desestruturadas” (2005, p. 11).

O estudo já pontuou que as políticas públicas brasileiras tendenciam a lógica da centralidade na família, a qual faz com que essa seja a principal responsável pela resolução dos problemas existentes, sem levar em consideração as múltiplas expressões da questão social e ainda, são culpabilizadas quando não conseguem "dar conta" do amparo. Essa família ora é vista como provedora de cuidados, ora como incriminada.

Mioto indica que "a capacidade do cuidado e da proteção dos grupos familiares depende diretamente da qualidade de vida que eles têm no contexto social nos quais estão inseridos" (2004, p. 121). Nesta direção, Oliveira e Americano (2003) analisam sobre essas famílias que "não conseguem cumprir seu papel”, “(...) temos ciência de que cada uma delas só pode dar aquilo de que efetivamente dispõe e que boa parte destas famílias também não encontra, na sociedade, o respaldo de que necessita para reunir condições de cuidar bem de seus filhos" (2003, p. 23).

De fato, retomando o conceito de criminalização da pobreza, a negligência é imputada para as mulheres pobres. E essa imputabilidade, para Barros, Barros e Freitas (2014) tem como grande autor o Estado ao culpar as mulheres pobres e suas famílias. Diante disso, suscita-se que a situação de pobreza ainda é um grande obstáculo para a permanência das mães junto aos seus filhos, no entanto, há inúmeros outros fatores que dificultam tal fato, como a falta de suporte do Estado por meio de políticas públicas.

Considera-se que não adianta apenas haver normas se não há o compromisso na qualidade da prestação dos serviços e participação dos usuários. Nesse sentido, pontua-se a necessidade de colocar em prática esse conjunto de leis a partir de um trabalho intersetorial e interdisciplinar com ações que possibilitem a garantia de direitos, potencializando os sujeitos e dando importância à preservação dos vínculos familiares, independentemente dos recursos financeiros. 


\section{Convivência Familiar}

E por que realizar um trabalho na perspectiva da convivência familiar? Tal proposta é decorrente do fato de a questão das drogas ser muita complexa e não envolver apenas o usuário, como também o seu ciclo de relacionamentos, principalmente os familiares. Assim, verifiquei ao longo da minha experiência profissional que a família é um importante eixo para a efetividade do tratamento. Por isso, recomenda-se a necessidade de potencializá-la para participar de ações de orientação, apoio e intervenção promovidas pela rede de serviços e seus profissionais.

Para a definição de convivência familiar e comunitária utilizaremos: "a possibilidade da criança permanecer no meio a que pertence. De preferência junto à sua família, ou seja, seus pais ou outros familiares ou, caso isso não seja possível, em outra família que possa acolher" (Rizzini, Rizzini, Naiff e Baptista, 2005, p. 12).

A partir disso, a convivência familiar será apreciada como o retorno à família de origem ou a possibilidade de construção de um novo ambiente familiar formado pela puérpera e o bebê. Para isso, pontua-se a importância da rede de cuidados ${ }^{58}$ para que seja estimulado o vínculo entre a mãe e a criança.

Retomando ao âmbito da convivência familiar, o art. 19 do Estatuto da Criança e do Adolescente expressa que:

Toda criança ou adolescente tem direito a ser criado e educado no seio da sua família e, excepcionalmente, em família substituta, assegurada a convivência familiar e comunitária, em ambiente livre da presença de pessoas dependentes de substâncias entorpecentes. (grifo nosso)

A legislação brasileira vigente preconiza a família como um "espaço ideal" para o desenvolvimento dos indivíduos. Porém, como relatam Rizzini, Rizzini, Naiff e Baptista (2006), para que o exposto artigo 19 do Estatuto seja possível, cabe ao Poder Público assegurar as condições necessárias. Os autores ainda

\footnotetext{
58 Com relação à categoria "cuidado", no sentido etimológico, Duarte analisa que (...) é de origem latina, derivada do verbo cogitare, mas que tem referência no vocábulo latino, curare. Assim, enquanto o verbo cogitare origina-se do vocábulo co-agitare, significando agitação de pensamento, revolver no espírito, ou tornar a pensar em alguma coisa, em suma: pensar, supor e imaginar, curare, por outro lado, em sua forma mais antiga, se escrevia coera, era usada em contexto de relação de amor e de amizade, implicando em tratar, curar, de pôr cuidado (2013, p. 76-77).
} 
acrescentam que no Brasil atribui-se uma responsabilidade à família incompatível com as condições de vida em que se encontra o contexto familiar.

É corrente que muitas das vezes, para manter o consumo, o usuário de drogas passa a cometer crimes, se prostituir, traficar e até mesmo a vender os bens que possui em casa. Assim, as famílias se veem desesperadas com essas ocorrências e principalmente, quando precisam buscar seus parentes em cracolândias ou resgatá-los de traficantes que ameaçam os familiares para que as dívidas sejam pagas a qualquer custo. Diante disso, na tentativa de manter o controle, para Vasconcelos, as famílias utilizam-se dos seguintes dispositivos: "cárcere privado nas casas, a busca de qualquer tipo de lugar para a internação de longa permanência, a prisão policial, o abandono nas ruas ou em áreas remotas, e em alguns casos, a própria eliminação física etc (2012, p. 173). Por tudo isso, enfatiza-se que é indispensável a ajuda ao conjunto - usuário e família.

Adiciona-se que o suporte à família é preconizado pela Política Nacional de Drogas de 2005 em seu capítulo sobre "Tratamento recuperação e reinserção social":

\begin{abstract}
$O$ acesso às diferentes modalidades de tratamento e recuperação, reinserção social e ocupacional deve ser identificado, qualificado e garantido como um processo contínuo de esforços disponibilizados, de forma permanente, para os usuários, dependentes e seus familiares, com investimento técnico e financeiro de forma descentralizada (Brasil, 2005, grifos nossos).
\end{abstract}

\title{
Componentes da Rede de Atenção Psicossocial (RAPS)
}

Considerando-se os problemas relacionados ao uso de álcool e outras drogas têm sua origem em vários aspectos, como a história de vida, os contextos econômico, social e cultural, entre outros fatores. Assim, essa questão transcende o âmbito estritamente clínico e requer um acompanhamento periódico. Por isso, a necessidade de se conhecer a rede de atenção psicossocial para que seja realizada uma abordagem de cunho intersetorial e interdisciplinar.

Com essa perspectiva, optamos por realizar um mapeamento dos dispositivos de cuidados no território do hospital universitário para a construção 
de rede de atenção voltada para as puérperas com "uso problemático de drogas" 59 .

Ressalta-se que a heterogeneidade em virtude da inserção em diferentes contextos requer ações que sejam efetivas para o conjunto de pacientes, mas que também atendam as suas especificidades. Posto isso, é difícil um modelo ideal em virtude das diversas problemáticas já apresentadas ao longo do trabalho.

É importante sinalizar que o mapeamento foi realizado no território do hospital. Contudo, na hipótese de usuários residentes em outras áreas serão realizadas novas pesquisas que contribuirão para a elaboração de um catálogo de recursos para o setor de serviço social do hospital.

Serão apresentados equipamentos da área da saúde, porém não se exclui a relevância da intersetorialidade neste processo, ou seja, a interlocução com outros setores para que a atenção integral seja efetivada, como assistência, justiça, educação, segurança pública etc.

Como já sinalizado, a portaria ํo. 3.088/11 institui a Rede de Atenção Psicossocial para pessoas com sofrimento ou transtorno mental e com necessidades decorrentes do uso de crack, álcool e outras drogas, no âmbito do Sistema Único de Saúde (SUS). O art. 5ํㅜ desta normativa expressa os componentes da rede de atenção psicossocial, os quais serão estruturados no quadro a seguir para possibilitar uma melhor visualização.

\footnotetext{
59 Será considerado por uso problemático de drogas, as pessoas que são dependentes químicas: "Na última Classificação Internacional de Doença (CID 10), no capítulo $F$, foram referidos os quadros de dependência a drogas como Síndrome de Dependência as Drogas,como um estado que reunia alguns dos seguintes sintomas: 'envolve o desejo pronunciado de tomar a substância, a dificuldade de controlar o uso, estados de supressão fisiológica, tolerância, descaso de outros prazeres e interesses e uso persistente não obstante os danos causados à própria pessoa e aos outros' (OPAS/OMS, 2001, p. 58). Conquanto, a despeito das lutas concorrenciais na área de álcool e de outras drogas para imputar certas noções como 'científicas', em certos momentos históricos, o termo dependência, contido no texto, pode o seu sentido ser apreendido próximo ao da versão do CID 1059" (LIMA, 2005, p. 2).
} 
Quadro 1 - Componentes da Rede de Atenção Psicossocial

\begin{tabular}{|c|c|}
\hline \multirow{3}{*}{$\begin{array}{l}\text { I - atenção básica em saúde, formada } \\
\text { pelos seguintes pontos de atenção }\end{array}$} & a) Unidade Básica de Saúde; \\
\hline & $\begin{array}{l}\text { b) equipe de atenção básica para } \\
\text { populações específicas: } \\
\text { 1. Equipe de Consultório na Rua; } \\
\text { 2. Equipe de apoio aos serviços do } \\
\text { componente Atenção Residencial de } \\
\text { Caráter Transitório; }\end{array}$ \\
\hline & c) Centros de Convivência; \\
\hline $\begin{array}{l}\text { II - atenção psicossocial } \\
\text { especializada, formada pelos } \\
\text { seguintes pontos de atenção: }\end{array}$ & $\begin{array}{l}\text { a) Centros de Atenção Psicossocial, nas } \\
\text { suas diferentes modalidades; }\end{array}$ \\
\hline \multirow{5}{*}{$\begin{array}{c}\text { III - atenção de urgência e } \\
\text { emergência, formada pelos seguintes } \\
\text { pontos de atenção: }\end{array}$} & a) SAMU 192; \\
\hline & b) Sala de Estabilização; \\
\hline & c) UPA 24 horas; \\
\hline & $\begin{array}{l}\text { d) portas hospitalares de atenção à } \\
\text { urgência/pronto socorro; }\end{array}$ \\
\hline & $\begin{array}{l}\text { e) Unidades Básicas de Saúde, entre } \\
\text { outros; }\end{array}$ \\
\hline \multirow{2}{*}{$\begin{array}{c}\text { IV - atenção residencial de caráter } \\
\text { transitório, formada pelos seguintes } \\
\text { pontos de atenção: }\end{array}$} & a) Unidade de Recolhimento; \\
\hline & $\begin{array}{l}\text { b) Serviços de Atenção em Regime } \\
\text { Residencial; }\end{array}$ \\
\hline \multirow[b]{2}{*}{$\begin{array}{l}\text { V - atenção hospitalar, formada pelos } \\
\text { seguintes pontos de atenção: }\end{array}$} & $\begin{array}{l}\text { a) enfermaria especializada em Hospital } \\
\text { Geral; }\end{array}$ \\
\hline & $\begin{array}{l}\text { b) serviço Hospitalar de Referência para } \\
\text { Atenção às pessoas com sofrimento ou } \\
\text { transtorno mental e com necessidades } \\
\text { decorrentes do uso de crack, álcool e } \\
\text { outras drogas; }\end{array}$ \\
\hline $\begin{array}{c}\mathrm{VI} \text { - estratégias de } \\
\text { desinstitucionalização, formada pelo } \\
\text { seguinte ponto de atenção: }\end{array}$ & a) Serviços Residenciais Terapêuticos; e \\
\hline & \\
\hline
\end{tabular}


A partir disso, algumas conceituações serão realizadas para a compreensão da rede ${ }^{60}$ :

1 - Unidades Básicas de Saúde: Têm a responsabilidade de desenvolver ações de promoção de saúde mental, prevenção e cuidado dos transtornos mentais, ações de redução de danos e cuidado para pessoas com necessidades decorrentes do uso de crack, álcool e outras drogas, compartilhadas, sempre que necessário, com os demais pontos da rede.

Neste âmbito, em conformidade com $\circ \S 2^{\circ}$ do art. $6^{\circ}$ da Portaria $\mathrm{n}^{\circ} 3.088$ de 23/12/11, tem-se o Núcleo de Apoio à Saúde da Família, o qual é constituído por profissionais de saúde de diferentes áreas de conhecimento, que atuam de maneira integrada, sendo responsável por apoiar as Equipes de Saúde da Família, as Equipes de Atenção Básica para populações específicas e equipes da academia da saúde. De acordo com Magalhães Junior se exige "uma atenção básica atenta ao problema e capacitada para o seu diagnóstico e acompanhamento em primeiro nível (...)" (2014, p. 27).

No âmbito da saúde mental, Assis et. al (2004) aponta a necessidade da descentralização de ações focadas a fim de se evitar estigmas individualizantes a partir de uma leitura do território onde se encontra o sujeito.

2 - Equipe de atenção básica para populações específicas:

a) Equipe de Consultório na Rua: constituída por profissionais que atuam de forma itinerante, ofertando ações e cuidados de saúde para a população em situação de rua, considerando suas diferentes necessidades de saúde. No âmbito da RAPS, é responsabilidade da Equipe do Consultório na Rua ofertar cuidados em saúde mental para (i) pessoas em situação de rua em geral; (ii) pessoas com transtornos mentais e (iii) usuários de crack, álcool e outras drogas, incluindo ações de redução de danos, em parceria com equipes de outros pontos de atenção da rede de saúde, como Unidades Básicas de Saúde, Centros de Atenção Psicossocial, Prontos-Socorros, entre outros.

b) Equipe de apoio aos serviços do componente Atenção Residencial de Caráter Transitório: oferece suporte clínico e apoio a esses pontos de atenção. Essa equipe multiprofissional coordena o cuidado e presta serviços de atenção à

60 As conceituações dos componentes foram retiradas da portaria $n$ ㅇ. 3.088/11 e do link: http://www.saude.rj.gov.br/atencao-a-saude/994-redes-tematicas/rede-de-atencao-

psicossocial/16443-rede-de-atencao-psicossocial-raps-2.html?showall=\&start=1. Acessado em 02/07/2015. 
saúde de forma longitudinal e articulada com os outros pontos de atenção da rede;

3 - Centros de Convivência: Unidade pública, articulada às Redes de Atenção à Saúde, em especial à RAPS, onde são oferecidos à população em geral espaços de sociabilidade, produção e intervenção na cultura e na cidade.

a) Centros de Atenção Psicossocial, nas suas diferentes modalidades: Constituídos por equipe multiprofissional, que atua sob a ótica da interdisciplinariedade, e realiza atendimento às pessoas com transtornos mentais graves e persistentes e às pessoas com necessidades decorrentes do uso de crack, álcool e outras drogas, em sua área territorial. O trabalho no CAPS é realizado prioritariamente em espaços coletivos (grupos, assembleias de usuários, reunião diária de equipe), de forma articulada com os outros pontos de atenção da RAPS e das demais redes. O cuidado é desenvolvido através de Projeto Terapêutico Individual, envolvendo em sua construção a equipe, o usuário e sua família. A ordenação do cuidado estará sob a responsabilidade do CAPS ou da Atenção Básica, garantindo permanente processo de cogestão e acompanhamento longitudinal do caso. De acordo com 0 § $4^{0}$ do art. $7^{0}$ da portaria no 3.088 de $23 / 12 / 11$, os CAPS estão organizados nas seguintes modalidades:

CAPS I - atende pessoas com transtornos mentais graves e persistentes e também com necessidades decorrentes do uso de crack, álcool e outras drogas de todas as faixas etárias; indicado para Municípios com população acima de vinte mil habitantes;

CAPS II - atende pessoas com transtornos mentais graves e persistentes, podendo também atender pessoas com necessidades decorrentes do uso de crack, álcool e outras drogas, conforme a organização da rede de saúde local, indicado para Municípios com população acima de setenta mil habitantes;

CAPS III - atende pessoas com transtornos mentais graves e persistentes. Proporciona serviços de atenção contínua, com funcionamento vinte e quatro horas, incluindo feriados e finais de semana, ofertando retaguarda clínica e acolhimento noturno a outros serviços de saúde mental, inclusive CAPS ad, indicado para Municípios ou regiões com população acima de duzentos mil habitantes; 
CAPS AD - atende adultos ou crianças e adolescentes, considerando as normativas do Estatuto da Criança e do Adolescente, com necessidades decorrentes do uso de crack, álcool e outras drogas. Serviço de saúde mental aberto e de caráter comunitário, indicado para Municípios ou regiões com população acima de setenta mil habitantes;

CAPS AD III - atende adultos ou crianças e adolescentes, considerando as normativas do Estatuto da Criança e do Adolescente, com necessidades de cuidados clínicos contínuos. Serviço com no máximo doze leitos leitos para observação e monitoramento, de funcionamento 24 horas, incluindo feriados e finais de semana; indicado para Municípios ou regiões com população acima de duzentos mil habitantes; e

CAPSi - atende crianças e adolescentes com transtornos mentais graves e persistentes e os que fazem uso de crack, álcool e outras drogas. Serviço aberto e de caráter comunitário indicado para municípios ou regiões com população acima de cento e cinquenta mil habitantes.

4 - Atenção de urgência e emergência, formada pelos seguintes pontos de atenção: são responsáveis, em seu âmbito de atuação, pelo acolhimento, classificação de risco e cuidado nas situações de urgência e emergência das pessoas com sofrimento ou transtorno mental e com necessidades decorrentes do uso de crack, álcool e outras drogas.

a) SAMU 192;

b) Sala de Estabilização;

c) UPA 24 horas;

d) portas hospitalares de atenção à urgência/pronto socorro;

e) Unidades Básicas de Saúde, entre outros;

5 - Atenção residencial de caráter transitório, formada pelos seguintes pontos de atenção, consoante o art. 9ํ da portaria no 3.088 de 23/12/11.

a) Unidade de Acolhimento - oferece cuidados contínuos de saúde, com funcionamento de vinte e quatro horas, em ambiente residencial, para pessoas com necessidade decorrentes do uso de crack, álcool e outras drogas, de ambos os sexos, que apresentem acentuada vulnerabilidade social e/ou familiar e 
demandem acompanhamento terapêutico e protetivo de caráter transitório cujo tempo de permanência é de até seis meses;

b) Serviços de Atenção em Regime Residencial, entre os quais Comunidades Terapêuticas - serviço de saúde destinado a oferecer cuidados contínuos de saúde, de caráter residencial transitório por até nove meses para adultos com necessidades clínicas estáveis decorrentes do uso de crack, álcool e outras drogas.

6 - Atenção hospitalar, formada pelos seguintes pontos de atenção: Serviço Hospitalar de Referência para Atenção às pessoas com sofrimento ou transtorno mental e com necessidades decorrentes do uso de crack, álcool e outras drogas, oferece suporte hospitalar aos usuários de álcool e/ou outras drogas, por meio de internações de curta duração, em situações assistenciais que evidenciarem indicativos de ocorrência de comorbidades de ordem clínica e/ou psíquica, acolhendo os pacientes em regime de curtíssima ou curta permanência. Funciona em regime integral, durante 24 horas diárias, nos sete dias da semana, sem interrupção da copaintinuidade entre os turnos. Em nível local ou regional, compõem a rede hospitalar de retaguarda aos usuários de álcool e outras drogas, observando o território, a lógica da redução de danos e outras premissas e princípios do SUS.

a) enfermaria especializada em Hospital Geral;

b) serviço Hospitalar de Referência para Atenção às pessoas com sofrimento ou transtorno mental e com necessidades decorrentes do uso de crack, álcool e outras drogas;

7 - Estratégias de desinstitucionalização, formada pelo seguinte ponto de atenção:

a) Serviços Residenciais Terapêuticos - São moradias inseridas na comunidade, destinadas a acolher pessoas egressas de internação de longa permanência (dois anos ou mais ininterruptos), egressas de hospitais psiquiátricos e hospitais de custódia, entre outros.

8 - Reabilitação psicossocial: Iniciativas de geração de trabalho e renda e Empreendimentos solidários e Cooperativas sociais. 


\section{Mapeamento dos serviços da Rede de Atenção Psicossocial no território do hospital universitário}

A cidade do Rio de Janeiro é dividida em 10 áreas programáticas. Essas áreas são as regiões de saúde do território que tem como definição:

(...) espaço geográfico contínuo constituído por agrupamentos de Municípios limítrofes, delimitado a partir de identidades culturais, econômicas e sociais e de redes de comunicação e infraestrutura de transportes compartilhados, com a finalidade de integrar a organização, o planejamento e a execução de ações e

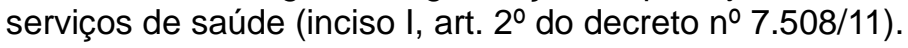

Por esse decreto, criou-se um contexto de efetivação da atenção psicossocial ao exigir em seu art. 5ำ que para ser instituída, a região de saúde "deve conter, no mínimo, ações e serviços de: I - atenção primária; II - urgência e emergência; III - atenção psicossocial; IV - atenção ambulatorial especializada e hospitalar; e V - vigilância em saúde".

As áreas programáticas do município do Rio de Janeiro estão configuradas no mapa a seguir ${ }^{61}$ :

Mapa 1 - Áreas Programáticas do município do Rio de Janeiro

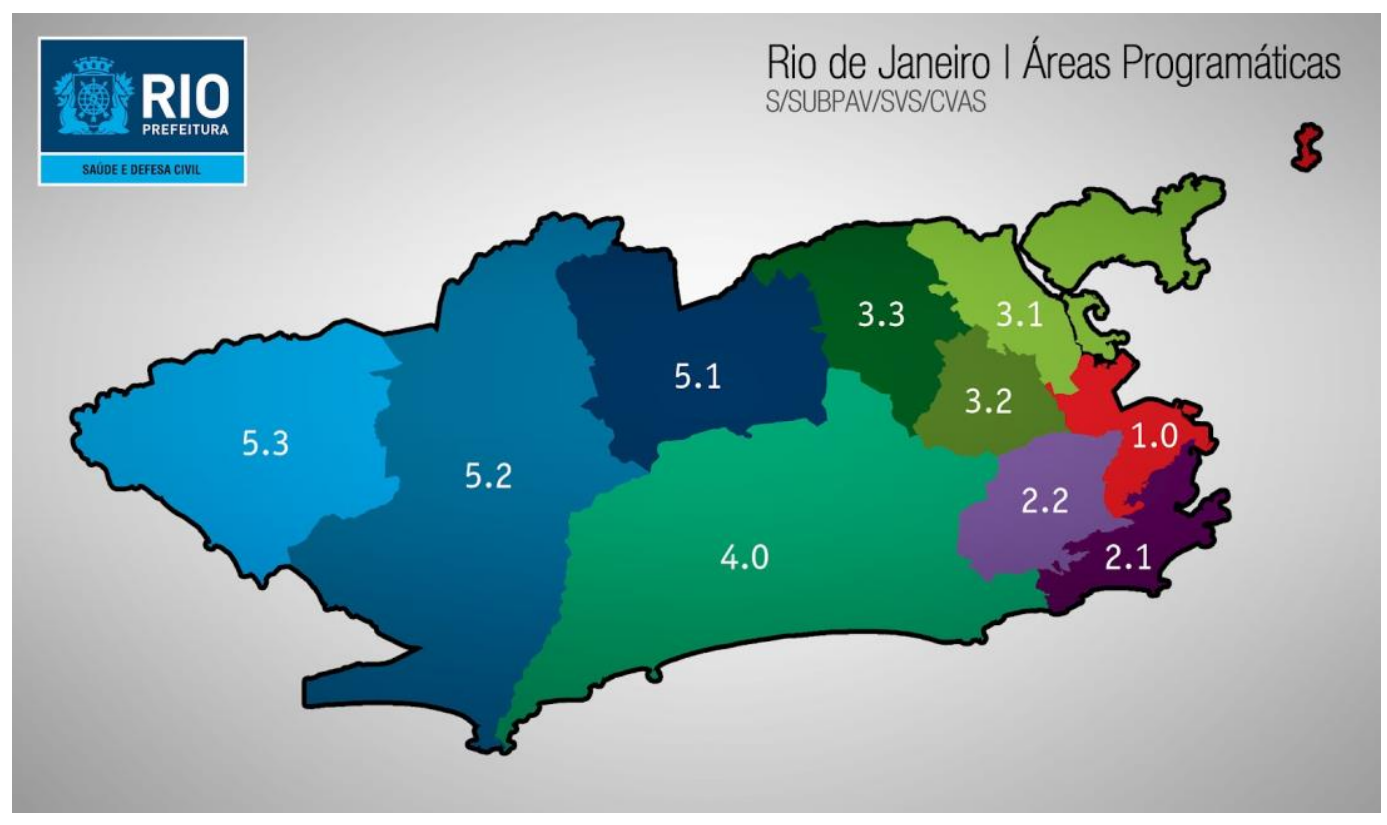

Fonte: http://cvasrio.blogspot.com.br/2012/02/areas-programaticas-bairros.html

O Hospital Universitário do estudo em questão é localizado na área programática 2.2 do município do Rio de Janeiro, a qual contempla os seguintes

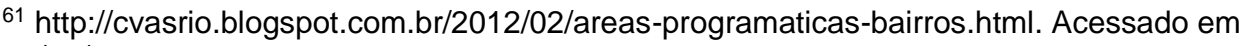
08/06/2015. 
bairros: Alto da Boa Vista, Andaraí, Grajaú, Maracanã, Praça da Bandeira, Tijuca e Vila Isabel. Sendo assim, e em consonância com o art. 5․ da portaria no . 3.088/11 que traz os componentes da rede de atenção psicossocial, o mapeamento da A.P. 2.2 foi realizado a partir do contato telefônico com 3 instituições, contato por email com a Coordenadoria da Área Programática, visita a 2 instituições. A partir disso, seguem abaixo os serviços disponibilizados na rede:

Quadro 2- Identificação da Rede de Atenção Psicossocial da Área Programática 2.2 para o suporte do trabalho desenvolvido na maternidade do hospital universitário

\begin{tabular}{|c|c|c|}
\hline \multicolumn{3}{|c|}{ Rede de Atenção Psicossocial da Área Programática 2.2} \\
\hline \multirow{7}{*}{$\begin{array}{c}\text { CENTRO MUNICIPAL DE } \\
\text { SAÚDE }\end{array}$} & $\begin{array}{l}\text { HEITOR BELTRÃO } \\
\text { POSSUI NÚCLEO DE } \\
\text { APOIO À SAÚDE DA } \\
\text { FAMÍLIA (NASF) }\end{array}$ & $\begin{array}{c}\text { Rua Desembargador Izidro, } \\
144 \text { - Tijuca - Telefones: } \\
2288-4388 / 8300 / 3238- \\
1787\end{array}$ \\
\hline & $\begin{array}{l}\text { HEITOR PELLEGRINO } \\
\text { POSSUI NÚCLEO DE } \\
\text { APOIO À SAÚDE DA } \\
\text { FAMÍLIA (NASF) } \\
\end{array}$ & $\begin{array}{c}\text { Rua do Matoso, } 96 \text { - Praça } \\
\text { da Bandeira - Telefones: } \\
\text { 2273-1194/0998/0844 }\end{array}$ \\
\hline & $\begin{array}{l}\text { MARIA AUGUSTA } \\
\text { ESTRELA } \\
\text { POSSUI NÚCLEO DE } \\
\text { APOIO À SAÚDE DA } \\
\text { FAMÍLIA (NASF) }\end{array}$ & $\begin{array}{l}\text { Rua Visconde de Santa } \\
\text { Isabel, } 34 \text { - Vila Isabel - } \\
\text { Telefones: } 3111- \\
6109 / 6107 / 6100\end{array}$ \\
\hline & NICOLA ALBANO & $\begin{array}{c}\text { Rua Boa Vista, } 190 \text { - Alto } \\
\text { da Boa Vista - Telefones: } \\
2492-5600 / 2153 \\
\end{array}$ \\
\hline & CASA BRANCA & $\begin{array}{c}\text { Estrada da Casa Branca, } \\
200 \text { - Tijuca - Telefone: } \\
2268-6531 \\
\end{array}$ \\
\hline & $\begin{array}{l}\text { CARLOS FIGUEIREDO } \\
\text { FILHO }\end{array}$ & $\begin{array}{l}\text { Rua São Miguel, S/№ - } \\
\text { Tijuca - Telefone: 2298- } \\
4175\end{array}$ \\
\hline & JULIO BARBOSA & $\begin{array}{c}\text { Rua Castel Nuovo, } 150 \\
\text { fundos - Tijuca - } \\
\text { Telefones: } 2238-9392 \\
2208-5846 \\
\end{array}$ \\
\hline \multirow{2}{*}{$\begin{array}{l}\text { CENTRO DE ATENÇÃO } \\
\text { PSICOSSOCIAL } \\
\text { (CAPS) }\end{array}$} & $\begin{array}{l}\text { CAPS AD (ÁLCOOL E } \\
\text { DROGAS) MANÉ } \\
\text { GARRINCHA }\end{array}$ & $\begin{array}{l}\text { Rua Professor Manoel de } \\
\text { Abreu, 196, Maracanã. } \\
\text { Telefones: 2284-6339/6860; }\end{array}$ \\
\hline & $\begin{array}{c}\text { CAPS II UERJ } \\
\text { (Universidade do Estado do } \\
\text { Rio de Janeiro) }\end{array}$ & $\begin{array}{l}\text { Av. Marechal Rondon, } 381 \text {, } \\
\text { São Francisco Xavier. } \\
\text { Telefones: } 2334-2371 / 2372 ;\end{array}$ \\
\hline $\begin{array}{l}\text { HOSPITAL DE } \\
\text { EMERGÊNCIA } \\
\text { PSIQUIÁTRICA }\end{array}$ & Instituto Phillippe Pinel & $\begin{array}{c}\text { Av. Venceslau Brás, } 65, \\
\text { Botafogo. Telefone: } 2542- \\
\text { 3049. Atende as APs 1.0, } \\
2.1 \text { e } 2.2 \text {. }\end{array}$ \\
\hline
\end{tabular}


Pelo mapeamento e em consonância com a portaria № 3.088 de 23/12/2011 seguem algumas considerações:

- Apesar da expansão, o território ainda carece de alguns componentes essenciais, porém há uma previsão breve da implantação de um CAPS III, CAPSi e Centro de Convivência. Por enquanto, o CAPSi utilizado é o CAMARIM, localizado na Av. Venceslau Brás, 71 fundos, Botafogo. Telefone: 3873-5574 atende a AP 2.1 também.

- A inserção dos Centros Municipais de Saúde (CMS) se deu pelo fato de se considerar que o indivíduo deve ser pensado a partir do seu território, ou seja, conhecer o seu cotidiano possibilita aos profissionais a realização de tratamentos e encaminhamentos condizentes com a singularidade dos casos, possibilitando o rastreamento de gestantes dependentes químicas. E essa aproximação ocorre principalmente pelos Núcleos de Apoio à Saúde da Família (NASF). Neste âmbito, ressalta-se a importância da educação continuada com os profissionais para que possam realizar um trabalho na perspectiva da prevenção e da detecção precoce de riscos.

- Um outro aspecto nos Centros Municipais de Saúde é a realização de encaminhamentos para os serviços de planejamento familiar, o que possibilitaria às mulheres em questão engravidarem quando desejarem. De acordo com o art. $2^{\circ}$ da Lei $n$ 을 9.263 de 12/01/96: “(...) entende-se planejamento familiar como o conjunto de ações de regulação da fecundidade que garanta direitos iguais de constituição, limitação ou aumento da prole pela mulher, pelo homem ou pelo casal".

- Mesmo que o CAPS II UERJ não seja um equipamento específico para álcool e drogas, durante a minha trajetória profissional, identifiquei no CAPS AD pacientes que eram usuários de drogas, porém, não são mais e que, no momento, necessitam de um atendimento voltado para as consequências do uso. Em reunião de equipe, chegou-se à conclusão de que não seria interessante o usuário ser tratado no ambiente do CAPS AD, mas sim, ser referenciado para o CAPS II.

- As situações de urgência ainda são um desafio, pois tanto na vida profissional como nos relatos de profissionais de vários estados, os quais presenciei no $11^{\circ}$ Congresso Brasileiro de Saúde Coletiva, há uma dificuldade de obtenção do Serviço de Atendimento Móvel (SAMU), principalmente quando são 
informados de que a pessoa que será resgatada encontra-se em situação de rua. Nesta direção, Assis et. al (2014) indicam que o preconceito e o estereótipo por parte de profissionais despreparados levam à negligência no cuidado das pessoas.

Pelo exposto e em consonância com a Reforma Psiquiátrica, verifica-se que houve uma considerável expansão da rede de serviços visando à inclusão social do paciente com problemas mentais. É preciso ressaltar que, na área de Saúde Mental, a oferta dos equipamentos próximos ao local dos pacientes facilita o tratamento, porém, conforme já observado ao longo do trabalho e após contato com alguns dos equipamentos, o caráter fragmentário e descontínuo das políticas sociais contribui para a dificuldade de operacionalização dos serviços. $E$ ainda não há um atendimento específico para as gestantes. O que se tem neste âmbito é uma proposta de criação de uma "casa para acolher mulheres grávidas que fazem uso abusivo de crack, e alternativas tanto para as mulheres como para as crianças em situação de extrema vulnerabilidade social", conforme afirmou o vice-prefeito e secretário de Desenvolvimento Social, Adilson Pires, na oficina Maternidade, Gênero e Acolhimento, realizada em 04/02/201562.

Durante a realização do mapeamento para este trabalho, ocorreu um caso de reincidência do estudo em tela. Aproximadamente um ano após a primeira ocorrência, a genitora e seu marido retornaram à maternidade deste hospital com as mesmas demandas anteriores. Informaram que o primeiro filho encontrase sob a guarda provisória da irmã da paciente. A todo momento, eles diziam que dessa vez queriam a criança, além disso, o marido, diferentemente do estigma traçado pela sociedade, informou que tinha estudo superior e mostrava algum conhecimento inclusive sobre a rede de serviços, fazendo críticas ao tratamento asilar. O marido da paciente acrescentou que o grande impasse com os familiares é que diziam apenas que ele e a esposa deveriam ser internados.

Assim, mais um caso encaminhado ao Judiciário e eu fui a profissional designada a levar a família. Enquanto eu aguardava eles pegarem os pertences e arrumar o bebê, observei o carinho que a paciente colocava a roupinha vermelha, conforme dito por ela: "para dar sorte". Na verdade, os pais só foram para a Vara da Infância porque uma assistente social do hospital solicitou para oportunizar a esses pais a "fala", pois, a orientação era só de levar o recém-

62 http://vivario.org.br/municipio-cria-abrigo-para-gravidas-usuarias-de-crack/. Acessado em 20/07/2015. Embora a reportagem seja titulada por "Município cria abrigo para grávidas usuárias de crack" pelo conteúdo da matéria identifica-se que é apenas um projeto. 
nascido. Onde está a dignidade desses pais de entender o que estava acontecendo e pleitear pelos seus direitos?

Diante disso, enquanto estávamos no transporte em direção à Vara da Infância, expliquei para eles sobre tudo o que aconteceria lá, e que eu conversaria com o comissariado para "dar voz a eles", além de explicar a importância da busca de um tratamento por que eles se interessem, explicando sobre os locais que eu já havia pesquisado e quem deveriam encontrar como referência.

Ao chegar à Vara, imediatamente, somos orientados a deixar a criança na creche, local todo arrumado com brinquedos, livros e televisão, onde tinha duas profissionais que cuidavam das crianças que ali se encontravam. Fui com a paciente e presenciei o momento mais triste de todo esse processo, quando a genitora pediu para amamentar o bebê, como uma forma de se manter mais tempo com ela. Alguns minutos depois, a creche recebe a ligação do comissariado para descer. Lágrimas desciam dos olhos da paciente: mais uma perda em sua vida. Quando fomos ao comissariado, me deparei com uma profissional conhecida por mim. Tal fato pode ter possibilitado a abertura de uma escuta aos genitores e orientação de como eles poderiam proceder para obter a sua filha, com uma fala não moralizadora, mas sim de apoio, necessária para aquele momento. Eles agradeceram a atenção e diziam constantemente que iriam tentar. O desfecho ainda não é sabido, pois a audiência ainda será realizada. Pelo exposto, o conhecimento da rede me propiciou ofertar maiores oportunidades para que pudessem, pelo menos, tentar superar as suas fragilidades.

Pelo exposto, verifica-se que tanto os bebês quanto as puérperas com uso abusivo de drogas possuem demandas que não podem ser atendidas apenas no âmbito do hospital universitário. Diante disso, percebeu-se a necessidade de conhecer os equipamentos existentes no território. Contudo, para que os serviços possam se efetivar, as parcerias precisam ir além da transferência de responsabilidades, pois não basta dizer ao paciente que ele possui o direito, mas sim, torná-lo acessível a partir da mobilização da rede.

A partir do mapeamento e dos contatos realizados com os profissionais dos dispositivos, espera-se articular o hospital universitário com a rede de atenção psicossocial da sua área programática para que sejam construídos espaços de promoção, prevenção e tratamento que possibilitem o 
desenvolvimento da autonomia e fortalecimento dos vínculos sociais das puérperas usuárias de drogas, respeitando as necessidades de cada usuária na perspectiva da convivência familiar. 


\section{4 \\ Considerações Finais}

A pesquisa teve como proposta a análise da Rede de Atenção Psicossocial (RAPS) no atendimento às puérperas usuárias de drogas no território do hospital universitário. A partir do estudo, identificou-se que essas mulheres são vítimas de uma constante violação de direitos, pois são tolhidas do acesso aos serviços e do direito de decisão da maternidade, tendo em vista que há uma preocupação restrita à proteção das crianças e, com isso, a separação do vínculo mãe e bebê, tendo as drogas como justificativa para tal fato.

Diante disso, verifiquei durante a minha experiência profissional que o direito à convivência familiar na perspectiva do retorno à família de origem ou, até mesmo, a partir da construção de uma nova família entre o recém-nato e a sua genitora é um dos grandes desafios. Sendo assim, considera-se que, não apenas essas mulheres-mães, como também os indivíduos de forma geral, não podem ser pensados de maneira isolada, mas sim em sua conjuntura. Portanto, no primeiro capítulo, realizo uma discussão sobre a influência das transformações societárias nos contextos familiares.

Observo que, mesmo com os novos arranjos familiares, o modelo nuclear burguês é ainda a referência quando se pensa em estrutura familiar e que, apesar de avanços substanciais no que diz respeito às relações de gênero, vêse que persiste a imagem da mulher como dona do lar e provedora do cuidado. Avalia-se que isso é fortalecido por uma perspectiva neoliberal que tem como discurso a priorização das famílias, entretanto, fornece uma rede de serviços compartimentada e transfere cada vez mais as responsabilidades estatais para o locus privado. Com isso, o âmbito familiar acaba sendo responsabilizado por suas fragilidades e, geralmente, a mulher é a que mais sofre a culpabilização pela falha no cuidado dos membros.

No segundo capítulo, o foco recaiu sobre a Política de Saúde Mental, concretizada pela Reforma Psiquiátrica. Constatou-se que as transformações foram realizadas nos tratamentos ofertados aos seus pacientes, pois essa política conduziu mudanças na prática do cuidado ao alterar o modelo técnicoassistencial baseado na desinstitucionalização. Porém, a questão do uso de 
drogas (em nosso caso, as puérperas usuárias) ainda é vista de maneira preconceituosa, tendo como público-alvo principalmente a população pobre e negra, as maiores vítimas das medidas de repressão e controle. Tanto o usuário quanto seus familiares sofrem uma desqualificação moral e criminalizante.

Dentre os objetivos específicos, um aspecto significativo discutido foi a política de drogas adotada pelo Rio de Janeiro, a qual considera-se que é um retrocesso ao se basear na privação de liberdade como tratamento. Tal fato contrapõe-se ao proposto pela reforma psiquiátrica, a qual compreende que a saúde mental necessita ser realizada dentro de uma rede de cuidados ampla e integrada capaz de conduzir da melhor maneira possível as demandas dos usuários.

No terceiro capítulo, alguns pontos tiveram destaque como o constante encaminhamento dos recém-nascidos de mães usuárias de drogas para a Vara da Infância, Juventude e Idoso, sob a alegação da proteção dos bebês. Identificou-se que o carecimento das políticas públicas transferiu para o Judiciário a resolução para os conflitos do cotidiano. Na maioria dos casos, a genitora não é ouvida e as drogas têm sido a "desculpa" para que as mães pobres sejam impedidas de ficarem com os seus filhos sob a justificativa de não terem condições de cuidar, ou seja, a negligência é imputada às mulheres pobres. Assim, o direito à convivência familiar com o seu filho era suprimido de sua vida de uma maneira rude por meio da "simples" separação.

Não obstante, também há casos em que a mãe deseja entregar seu filho para adoção por considerar que será o melhor para ele. Contudo, o mito da maternidade e o preconceito por parte de alguns profissionais dificultam um atendimento adequado. Além disso, o cuidado é visto como uma vocação da mulher, fazendo com que o pai dificilmente protagonize nos relatórios das instituições e, em alguns casos, seja um "mero visitante" na maternidade.

Enfim, considerando que as drogas transcendem o âmbito meramente clínico e requer um acompanhamento periódico, a proposta foi identificar os serviços disponíveis na Rede de Atenção Psicossocial (RAPS) da área programática 2.2 do município do Rio de Janeiro no sentido de fornecer subsídios para as políticas e os serviços voltados para as mulheres com uso abusivo de drogas da maternidade do hospital universitário na perspectiva da convivência familiar. 
O estudo em questão aborda uma temática atual que perpassa diversas áreas, como assistência social, educação, segurança pública, mas o trabalho teve como foco o mapeamento ao âmbito da saúde. Pela análise da rede verifiquei que diversos desafios permeiam a temática como a ausência de um tratamento específico para as gestantes e puérperas usuárias de drogas, a falta de estabelecimentos públicos para acolher o binômio mãe e bebê, a necessidade de capacitação dos profissionais para lidar com essa problemática, a fragilidade da rede familiar, entre outros.

Enfim, apesar de um relativo número de equipamentos, a falta de articulação e a ausência de um Estado que valorize o "público" propiciam serviços precarizados e incipientes, todavia, com determinados profissionais que, mesmo nestas sutis condições, buscam realizar ações dignas aos seus usuários. Acrescenta-se que a falta de conhecimento da rede e a constante prática judicializante foram considerados grandes obstáculos para um atendimento pautado na integralidade.

Com isso, como proposta, conhecer a RAPS do território foi a estratégia sugerida para colaborar para o debate sobre o desconhecimento e a fragmentação dos serviços, possibilitando contribuir não somente com o atendimento na hospital, mas também, com a mobilização da rede de cuidados, dada a impossibilidade dos dispositivos responderem sozinhos às múltiplas demandas dos usuários.

Acreditamos que o mapeamento dos serviços propiciará maior visibilidade aos mesmos, por consequência, a possibilidade de uma maior adesão ao tratamento, pois nem sempre há interesse do usuário em aceitar o que foi proposto, embora não tenha sido um objetivo central deste estudo. Ressalta-se a importância de "dar voz" ao paciente para saber o que ele quer - o que espera.

Para isso, recomenda-se que os dispositivos da rede busquem uma atuação de forma articulada, objetivando garantir a integralidade da atenção e a intersetorialidade das políticas públicas. Além disso, para que os serviços possam se efetivar, as parcerias entre os setores precisam ir além da transferência de responsabilidades. Desse modo, propõe-se que a importância de uma atuação integrada seja trabalhada não apenas na formação acadêmica, como também de forma permanente, visto que se percebe claramente uma frágil articulação e a falta de clareza das atribuições profissionais, além de 
tensionamentos entre as equipes, principalmente o "ego médico", que faz com que alguns médicos considerem a sua opinião como soberana.

Como discutimos, é fundamental que se compreenda a complexidade do problema e que se construam propostas de acesso aos direitos, promovendo a potencialização dos usuários e familiares. Dessa maneira, acreditamos que o atendimento com as puérperas do estudo deve ocorrer não no sentido de culpabilizá-las pelas suas vulnerabilidades - as quais são oriundas dos desafios postos pela contemporaneidade como foi demonstrado --, mas sim, na lógica de um suporte, local de pertencimento, carinho, afeto, vínculo, ou seja, trabalhar na perspectiva da convivência familiar. Por isso, a importância de atender as famílias conjuntamente com os usuários e protagonizá-las, mesmo num diapasão de políticas públicas incipientes e com alguns profissionais desmotivados.

Espera-se que esta dissertação contribua para a criação de estratégias que facilitem a comunicação entre os equipamentos da rede, assim como possibilitar ações que busquem uma maior valorização e qualificação dos profissionais envolvidos, além da tentativa de romper com o hiato que há entre as leis e a prática, a fim de oportunizar a efetivação dos direitos conquistados e o respeito dos usuários de drogas, superando alguns desafios registrados no decorrer desta dissertação. 


\section{Referências Bibliográficas}

AGUINSKY, B. G.; ALENCASTRO, E. H. Judicialização da questão social: rebatimentos nos processos de trabalho dos assistentes sociais no Poder Judiciário. v. 9, n. 1. Florianópolis: Katálysis, 2006, p. 19-26.

ALENCAR, M. M. T. Família, Trabalho e Reprodução Social: Limites na Realidade Brasileira. In: DUARTE, M. J. O.; ALENCAR, M. M. T. (Orgs.). Família \& família: práticas sociais e conversações contemporâneas. 3. ed. Rio de Janeiro: Lumen Juris, 2013, p.133-152.

ALVES, V. S. Modelos de atenção à saúde de usuários de álcool e outras drogas: discursos políticos, saberes e práticas. Caderno de Saúde Pública. v. 25, n. 11, Rio de Janeiro, 2009.

AMARANTE, P. Loucos pela vida: uma trajetória da reforma psiquiátrica no Brasil. 2. ed. Rio de Janeiro: FIOCRUZ, 1998.

ANDERSON, P. Pós-neoliberalismo: as política sociais e o Estado democrático. São Paulo: Paz e Terra, 1995.

ANTUNES, R. Adeus ao trabalho? Ensaio sobre as metamorfoses e a centralidade do mundo do trabalho. São Paulo: Cortez, 2003.

ASSIS, J. T.; BARREIROS, C. A.; JACINTO, A. B. M. et al. Políticas de saúde mental no novo contexto do Sistema Único de Saúde: regiões e redes. Revista Divulgação em saúde para debate, n. 52. Rio de Janeiro: CEBES - Centro Brasileiro de Estudos de Saúde, 2014, p. 88113.

AZEVEDO, E.; PELICIONI, M. C. F.; WeSTPHAL, M. F. Práticas Intersetoriais nas Políticas Públicas de Promoção de Saúde. v. 22, n. 4. Rio de Janeiro: Physis, 2012, p. 1333-1356.

BARISON, M. S. A judicialização e a despolitização da questão social: duas faces de uma mesma moeda. O Social em questão, v. 1, n. 31. Revista do programa de pós-graduação do departamento de Serviço Social da PUC. Rio de Janeiro: PUC-Rio, 2014, p. 15 - 32. 
BARROS, M. I. V.; BARROS, N. V.; FREITAS, R. C. S. A influência da Lei 12.010/2009 para a judicialização e seus efeitos na vida de mulheres na cidade de Niterói/RJ. O Social em questão, v. 1, n. 31. Revista do programa de pós-graduação do departamento de Serviço Social da PUC. Rio de Janeiro: PUC, 2014, p. 163 - 176.

BEHRING, E. R. Brasil em contra-reforma: desestruturação do Estado e da perda dos direitos. São Paulo: Cortez, 2003.

O Brasil e a mundialização do capital: privatização, deslocalização e flexibilização das relações de trabalho. In: Trabalho e reprodução: enfoque e abordagens. 1. Ed., São Paulo: Cortez, 2001.

BEHRING, E. R.; BOSCHETTI, I. Politica Social: fundamentos e história. 5a. edição. São Paulo: Cortez, 2008.

BISNETO, J. A. Serviço social e saúde mental: uma análise institucional da prática. 3. ed. São Paulo: Cortez, 2011.

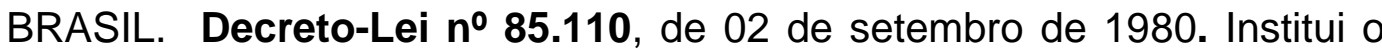
Sistema Nacional de Prevenção, Fiscalização e Repressão de Entorpecentes e dá outras providências, 1980.

Atenção psicossocial a crianças e adolescentes no SUS: tecendo redes para garantir direitos. Ministério da Saúde, Conselho Nacional do Ministério Público. - Brasília: Ministério da Saúde, 2014.

Constituição da República Federativa do Brasil, 1988.

Crack, é possível vencer. Disponível em: <http://www2.brasil.gov.br/crackepossivelvencer/home>. Acessado em 01 mar. 2015.

Decreto-Lei no 4.345, de 26 de agosto de 2002. Institui a Política Nacional Antidrogas e dá outras providências, 2002.

Decreto-Lei no 6.117, de 22 de maio de 2007. Aprova a Política Nacional sobre o Álcool, dispõe sobre as medidas para redução do uso indevido de álcool e sua associação com a violência e criminalidade, e dá outras providências, 2007.

Decreto-Lei no 7.179, de 20 de maio de 2010. Institui o Plano Integrado de Enfrentamento ao Crack e outras Drogas, cria o seu Comitê Gestor, e dá outras providências, 2010. 
BRASIL. Decreto-Lei no 7.508, de 28 de junho de 2011. Regulamenta a Lei no 8.080, de 19 de setembro de 1990, para dispor sobre a organização do Sistema Único de Saúde - SUS, o planejamento da saúde, a assistência à saúde e a articulação interfederativa, e dá outras providências, 2011.

Penal, 1940.

Decreto-Lei no 2.848, de 7 de dezembro de 1940. Código

Decreto-Lei no 891, de 25 de novembro de 1938. Aprova a Lei de Fiscalização de Entorpecentes, 1983.

Lei $\mathrm{n}$ - 11.343, de 23 de Agosto de 2006. Institui o Sistema Nacional de Políticas Públicas sobre Drogas - Sisnad; prescreve medidas para prevenção do uso indevido, atenção e reinserção social de usuários e dependentes de drogas; estabelece normas para repressão à produção não autorizada e ao tráfico ilícito de drogas; define crimes e dá outras providências, 2006.

Lei no 12.010, de 3 de agosto de 2009. Dispõe sobre adoção; altera as Leis nos 8.069, de 13 de julho de 1990 - Estatuto da Criança e do Adolescente, 8.560, de 29 de dezembro de 1992; revoga dispositivos da Lei no 10.406, de 10 de janeiro de 2002 - Código Civil, e da Consolidação das Leis do Trabalho - CLT, aprovada pelo Decreto-Lei no 5.452, de 10 de maio de 1943; e dá outras providências. 2009.

Lei $n=6.368$, de 21 de outubro de 1976. Dispõe sobre medidas de prevenção e repressão ao tráfico ilícito e uso indevido de substâncias entorpecentes ou que determinem dependência física ou psíquica, e dá outras providências, 1976. (Revogada).

. Lei no 8.069, de 13 de julho de 1990. Dispõe sobre o Estatuto da Criança e do Adolescente e dá outras providências, 1990.

Lei $n=8.080$, de 19 de setembro de 1990 . Dispõe sobre as condições para a promoção, proteção e recuperação da saúde, a organização e o funcionamento dos serviços correspondentes e dá outras providências, 1990.

Lei $n^{\circ}$ 9.263, de 12 de janeiro de 1996. Regula $\circ \S 7^{\circ}$ do art. 226 da Constituição Federal, que trata do planejamento familiar, estabelece penalidades e dá outras providências, 1996.

Lei no 10.216, de 6 de abril de 2001. Dispõe sobre a proteção e os direitos das pessoas portadoras de transtornos mentais e redireciona 0 modelo assistencial em saúde mental, 2001. 
BRASIL. Lei no 10.409, de 11 de janeiro de 2002. Dispõe sobre a prevenção, o tratamento, a fiscalização, o controle e a repressão à produção, ao uso e ao tráfico ilícitos de produtos, substâncias ou drogas ilícitas que causem dependência física ou psíquica, assim elencados pelo Ministério da Saúde, e dá outras providências, 2002. (Revogada)

Lei no 5.726, de 29 de outubro de 1971. Dispõe sobre medidas preventivas e repressivas ao tráfico e uso de substâncias entorpecentes ou que determinem dependência física ou psíquica e dá outras providências, 1971. (Revogada)

2002.

Lei no. 10.406, de 10 de janeiro de 2002. Institui o Código Civil.

Política do Ministério da Saúde para atenção integral a usuários de álcool e outras drogas. Brasília: Ministério da Saúde, 2003.

Portaria no 3.088, de 23 de dezembro de 2011. Institui a Rede de Atenção Psicossocial para pessoas com sofrimento ou transtorno mental e com necessidades decorrentes do uso de crack, álcool e outras drogas, no âmbito do Sistema Único de Saúde (SUS).

Reforma psiquiátrica e política de saúde mental no Brasil. Documento apresentado à Conferência Regional de Reforma dos Serviços de Saúde Mental: 15 anos depois de Caracas. OPAS. Brasília, novembro de 2005.

Saúde mental no SUS: os centros de atenção psicossocial. Brasília: Ministério da Saúde, 2004.

BRAVO, M. I. S. Frente nacional contra a privatização e sua luta em defesa da saúde pública estatal. Revista Serviço Social e Sociedade, n. 105, a. XXVII. São Paulo: Cortez, 2011, p. 185-193.

BRAZ, M.; NETTO, J. P. Economia política: uma introdução crítica Biblioteca básica de Serviço Social. v. 1, São Paulo: Cortez, 2006.

CARLOTO, C. M. Gênero, políticas públicas e centralidade na família. Revista Serviço Social e Sociedade. n. 86. Ano XXVII. São Paulo: Cortez, 2006.

CENTRO BRASILEIRO DE INFORMAÇÕES SOBRE DROGAS (CEBRID). II Levantamento Domiciliar sobre o Uso de Drogas Psicotrópicas no Brasil, 2005. 
CENTRO CULTURAL DE SAÚDE (CCS). A reforma psiquiátrica brasileira e a política de saúde mental. Disponível em <http://www.ccs.saude.gov.br/vpc/reforma.html>. Acesso em 12 fev. 2015.

CONSELHO REGIONAL DE SERVIÇO SOCIAL DO RIO DE JANEIRO (CRESS - RJ). Oficinas de debates sobre a maternidade de jovens em situação de rua e/ou usuárias de drogas $e$ a atenção aos seus bebês. Disponível em: <http://www.cressrj.org.br/site/eventos-cress/2711-e-312oficinas-de-debates-sobre-a-maternidade-de-jovens-em-situacao-de-ruaeou-usuarias-de-drogas-e-a-atencao-aos-seus-bebes/>. Acesso em 08 abr. 2015.

COUTO, M. C. V. Política de Saúde Mental para crianças e adolescentes: especificidades e desafios da experiência brasileira (20012010). Rio de Janeiro: Instituto de Psiquiatria da Universidade Federal do Rio de Janeiro (IPUB-UFRJ), 2012. 178 p. Tese (Doutorado) - Programa de Pós-Graduação em Psiquiatria e Saúde Mental, Instituto de Psiquiatria, Universidade Federal do Rio de Janeiro (IPUB-UFRJ), Rio de Janeiro, 2012.

D'INCAO, M. A. A mulher e a família burguesa. São Paulo: Contexto, 1997.

DELGADO, P. G. G. No litoral do vasto mundo. Lei 10.216 e a amplitude da Reforma psiquiátrica. In: VENÂNCIO, A. T.; CAVALCANTI, M. T. (Orgs.). Saúde Mental: campo saberes e discursos. Rio de Janeiro: IPUB/CUCA, 2001, p. 283-90.

DRAIBE, S. M. Políticas sociais e o neoliberalismo. Dossiê Liberalismo/Neoliberalismo. Revista da USP, n. 17. São Paulo: USP, mar/abr/mai, 1993. p. 86-101.

DUARTE, M. J. O. Loucura e família: $(R e)$ pensando o Ethos da produção do cuidado. In: DUARTE, M. J. O.; ALENCAR, M. M. T. (Orgs.). Família \& família: práticas sociais e conversações contemporâneas. 3. ed. Rio de Janeiro: Lumen Juris, 2013, p.75-94.

ELY, F. R. Serviço Social e Interdisciplinaridade. Revista Katálysis, v. 6, n. 1, jan./jun. Florianópolis: EDUFSc, 2003, p.113-117.

ENGELS, F. A origem da família, da propriedade privada e do Estado. 8. ed. Rio de Janeiro: Civilização Brasileira, 1982.

FACHIN, R. A. G. Em busca da família do novo milênio, uma reflexão crítica sobre as histórias e as perspectivas do Direito de Família Brasileiro Contemporâneo. Rio de Janeiro: Renovar, 2001. 
FOUCAULT, M. Vigiar e punir: nascimento da prisão; tradução de Raquel Ramalhete, 41. ed. Petrópolis, Rio de Janeiro: Vozes, 2013.

FRANCO, T. B. As Organizações Sociais e o SUS. Conferência Nacional de Saúde, 1998.

FUNDAÇÃO OSWALDO CRUZ (FIOCRUZ). Estimativa do número de usuários de crack e/ou similares nas capitais do país. Disponível em: $<$ http://portal.fiocruz.br/pt-br/content/maior-pesquisa-sobre-crackj\%C3\%A1-feita-no-mundo-mostra-o-perfil-do-consumo-no-brasil>. Acesso em 04 set. 2015.

FUNDAÇÃO OSWALDO CRUZ (FIOCRUZ). Reforma Sanitária. Disponível em: <http://bvsarouca.cict.fiocruz.br/sanitarista05.html>. Acesso em 13 fev. 2015.

GALVÁN, G. B. Equipes de Saúde: O desafio da integração disciplinar. Revista SBPH, v. 10, n. 2. Rio de Janeiro, 2007.

GARCIA, M. L. T.; LEAL, F. X.; ABREU, C. C. A política antidrogas brasileira: velhos dilemas. Psicologia e sociedade, n. 20, 2008.

GIDDENS, A. A transformação da intimidade. 2. ed. São Paulo: UNESP, 1993.

GOIS, D. A. Adoção consentida: do desenraizamento social da família à prática de adoção aberta. São Paulo: Cortez, 2013.

IAMAMOTO, M. V. O Serviço Social na contemporaneidade, trabalho e formação profissional. 8a․ edição. São Paulo: Cortez, 2005.

IAMAMOTO, M. V. Serviço Social em tempo de capital fetiche: capital financeiro, trabalho e questão social. 4. ed. São Paulo: Cortez, 2010.

INOJOSA, R. M. Intersetorialidade e a configuração de um novo paradigma organizacional. RAP, Rio de Janeiro, n. 32, p. 35-48, mar./abr. 2001.

INSTITUTO BRASILEIRO DE GEOGRAFIA E ESTATÍSTICA (IBGE). Pesquisa Nacional por Amostra de Domicílios (PNAD), 2012. Disponível em: <http://www.ipea.gov.br/portal/index.php?option=com _content\&view=article\&id=19998 > . Acesso em 18 ago. 2015.

LAURELL, A. C. Avançando em direção ao passado: a política social do neoliberalismo. In: (Org.). Estado em políticas sociais no neoliberalismo. São Paulo: Cortez, 1995. p. 151-178. 
LIMA, R. C. C.; TAVARES, P. Desafios recentes às políticas sociais brasileiras sobre as drogas: enfrentamento ao crack e proibicionismo. Revista Argumentum, Vitória /ES, v. 4, n. 2, jul./dez. 2012, p. 6-23.

LIMA, R. C. C. Álcool e outras drogas como desafio para saúde e as políticas intersetoriais: contribuições para IV Conferência Nacional de Saúde Mental - Intersetorial. In: VASCONCELOS. Desafios Políticos da Reforma Psiquiátrica Brasileira. São Paulo: Hucitec, 2010.

Mundialização e as políticas públicas contemporâneas de atenção ao usuário de álcool e outras drogas: o caso brasileiro. III Jornada Internacional de Políticas Públicas. Universidade Federal do Maranhão - 23 a 26 de ago. 2005.

LIMA, R. C. C.; ROCHA, A. P.; VALE, Juliana Batistuta e FONSECA, Adriana Pereira da. Políticas sociais sobre drogas: um objeto para Serviço Social brasileiro. Revista Argumentum, Vitória /ES, v. 7, n. 1, jan./jun. 2015, p. 26-38.

LÜCHMANN, L. H. H.; RODRIGUES, J. O movimento antimanicomial no Brasil. Cien Saude Colet, 2007, p. 399-407.

MAGALHÃES JUNIOR, H. M. Redes de Atenção à Saúde: rumo à integralidade. Revista Divulgação em saúde para debate, n. 52. Rio de Janeiro: CEBES - Centro Brasileiro de Estudos de Saúde, 2014, p. 15 37.

MINISTÉRIO DA SAÚDE. 1a. Conferência Nacional de Saúde Mental. Brasília, 1988. Disponível em: <http://bvsms.saude.gov.br/bvs/ publicacoes/0206cnsm_relat_final.pdf>. Acesso em $15 \mathrm{fev} .2015$.

2a. Conferência Nacional de Saúde Mental. Brasília, 1998. Disponível em: <http://bvsms.saude.gov.br/bvs/publicacoes/2conf _mental.pdf>. Acesso em 18 fev. 2015.

3a. Conferência Nacional de Saúde Mental. Brasília, 2002. Disponível em: <http://conselho.saude.gov.br/biblioteca /relatorios/saude_mental.pdf>. Acesso em 21 fev. 2015.

MINISTÉRIO DO DESENVOLVIMENTO SOCIAL E COMBATE À FOME (MDS). Conselho Nacional de Assistência Social. Norma Operacional Básica do Sistema Único de Assistência Social - NOB/SUAS. Brasília, 2005. 
MIOTTO, R. C. T. Família e Assistência Social: Subsídios para o Debate do Trabalho dos Assistentes Sociais. In: DUARTE, M. J. O.; ALENCAR, M. M. T. (Orgs.). Família \& família: práticas sociais e conversações contemporâneas. 3. ed. Rio de Janeiro: Lumen Juris, 2013, p. 03-14.

Família e Serviço Social: contribuições para o debate. Revista Serviço Social e Sociedade. n. 55, a. XVIII. São Paulo: Cortez, 2004.

Novas propostas e velhos princípios: a assistência às famílias no contexto de programas de orientação e apoio sociofamiliar. In: MIONE, A. S.; MATOS, M. C.; LEAL, M. C. (Orgs.). Política social, família e juventude: uma questão de direitos. 3. ed. Rio de Janeiro: Cortez, 2008, p. 43-60.

MIRANDA, F. C. P. Tratado de Direito de Família. Campinas: Bookseller, 2001.

MONNERAT, G. L.; SOUZA, R. G. Da seguridade social à intersetorialidade: reflexões sobre a integração de políticas sociais no Brasil. Revista Katálysis. Florianópolis, 2011, p. 41-49.

MORGADO, R. Mulheres/mães e o abuso incestuoso. Rio de Janeiro: Editora UFRJ, 2012.

. Violência doméstica: sinônimo de mulheres/mães culpadas? 0

Social em questão, v. 28, n. 28 . Revista do programa de pós-graduação do departamento de Serviço Social da PUC. Rio de Janeiro: PUC, 2012. p. $221-231$.

NASCIMENTO, S. Reflexões sobre a intersetorialidade entre as políticas públicas. Revista Serviço Social e Sociedade. n. 101. São Paulo: Cortez, 2010, p. 95-120.

NOGUEIRA, A. C.; MONTEIRO, M. V. A família e a atenção em saúde: proteção, participação ou responsabilização? In: SILVA, L. B.; RAMOS, A. (Orgs.). Serviço Social, saúde e questões contemporâneas: reflexões críticas sobre a prática profissional. São Paulo: Papel Social, 2013, p. 139-160.

OLIVEIRA, A. C.; AMERICANO, N. S. Crianças e adolescentes em situação de rua: a difícil arte de cuidar. Rio de Janeiro: NOVA Pesquisa, 2003. 
OLIVEIRA, A. C. Abuso sexual intrafamiliar de crianças e ruptura do segredo: consequências para as famílias. Rio de Janeiro: PUC, 2011. 233 p. Tese (Doutorado) - Programa de Pós-Graduação em Serviço Social, Departamento de Serviço Social, Pontifícia Universidade Católica do Rio de Janeiro, Rio de Janeiro, 2011.

. Judicialização das Relações Sociais. O Social em questão, v. 31, n. 31. Revista do programa de pós-graduação do departamento de Serviço Social da PUC. Rio de Janeiro: PUC, 2014. p. 09 -12.

OLIVEIRA, F. Crítica à razão dualista/O ornitorrinco. São Paulo: Boitempo, 2003.

PAZZINATO, A. L.; SENISE, M. H. V. História Moderna e Contemporânea. 7. ed. São Paulo: Ática, 1994.

PEREIRA, P. A. Mudanças estruturais, política social e papel da família: crítica ao pluralismo de bem-estar. In: MIONE, A. S.; MATOS, M. C.; LEAL, M. C. (Orgs.). Política social, família e juventude: uma questão de direitos. 3. ed. Rio de Janeiro: Cortez, 2004, p. 43-60.

RIO DE JANEIRO. Plano estratégico da cidade do Rio de Janeiro. Disponível em: <http://www0.rio.rj.gov.br/planoestrategico/>. Acesso em 04 abr. 2015.

RIZZINI, I.; VALE, J. B. Ampliando oportunidades para crianças e adolescentes em situação de rua e em contextos de vulnerabilidade: entre processos democráticos e atravessamentos autoritários. ANAIS da $X$ Conferência Internacional: infância e juventude: processos de vulnerabilização e estratégias de resistência. Rio de Janeiro, 2013.

RIZZINI, I. Crianças, adolescentes e suas bases familiares: tendências e preocupações globais. In: SOUZA, S.; RIZZINI, I. (Coords.). Desenhos de Família - Criando filhos: a família goianiense e os elos parentais. Goiânia: Cânone Editorial, 2001, p. 23-44.

RIZZINI, I.; RIZZINI, Irma; NAIFF, L.; BAPTISTA, R. Crescer em família: revisitando concepções e práticas com vistas à promoção do direito à convivência familiar e comunitária. O Social em questão, v. 14, n.14. Revista do programa de pós-graduação do departamento de Serviço Social da PUC. Rio de Janeiro: PUC, 2005. p. 09 -30.

Acolhendo crianças e adolescentes: experiências de promoção do direito à convivência familiar e comunitária no Brasil. São Paulo: Cortez; Brasília/ DF: UNICEF; Rio de Janeiro: CIESPI/PUC-Rio, 2006. 
SANTOS, J. A. T.; OLIVEIRA, M. L. F. Políticas públicas sobre álcool e outras drogas: breve resgate histórico. Journal of Nursing Health, Pelotas/ RS, 2012, p. 82-93.

SANTOS, S. M. A.; RIFIOTIS, T. Cuidadores familiares de idosos dementados: um estudo crítico de práticas cotidianas e políticas sociais de judicialização e reprivatização. In: GROSSI, M. P.; SCHWADE, E. (Orgs.). Política e cotidiano: estudos antropólogos sobre gênero, família e sexualidade. Florianópolis: Nova letra, 2006. p. 95-114.

SARTI, C. A. Famílias Enredadas. In: VITALE, M. A. F.; ACOSTA, A. R. Famílias: redes, laços e políticas públicas. 6. ed. São Paulo: Cortez Coordenadoria de Estudos e Desenvolvimento de Projetos Especiais PUC-SP, 2015, p. 31-48.

SCHEFFER, G.; SILVA, L. G. Saúde mental, intersetorialidade e questão social: um estudo na ótica dos sujeitos. Revista Serviço Social e Sociedade, n. 118. São Paulo: Cortez, 2014.

SENAD. Prevenção ao uso indevido de drogas: Capacitação para Conselheiros e Lideranças Comunitárias. 4. ed. Brasília: Ministério da Justiça. Secretaria Nacional de Políticas sobre Drogas - SENAD, 2011.

Legislação e Políticas Públicas sobre Drogas. Brasília, Presidência da República, Secretaria Nacional de Políticas sobre Drogas, 2010.

Módulo I do curso da 7. ed. do curso SUPERA. Sistema para deteç̧ão do uso abusivo e dependência de substâncias psicoativas: encaminhamento, intervenção breve, reinserção social e acompanhamento, 2014.

SERRA, R. M. S. Alterações no mundo do trabalho e repercussões no mercado profissional do Serviço Social. Trabalho e reprodução: enfoque e abordagens. 1. ed. São Paulo: Cortez, 2001.

SILVA, A. F.; BARROSO, B. S. Descentralização/ intersetorialidade/territorialidade no campo da assistência social: 0 município de Campo dos Goytacazes como referência. III Jornada Internacional de Políticas Públicas. Universidade Federal do Maranhão 28 a 30 de agosto 2007.

SILVA, L. B.; MENDES, A. G. Serviço Social, saúde e a interdisciplinaridade: algumas questões para o debate. In: SILVA, L. B.; RAMOS, A. (Orgs.). Serviço Social, saúde e questões contemporâneas: reflexões críticas sobre a prática profissional. São Paulo: Papel Social, 2013, p. 49-64. 
SISTEMA ÚNICO DE SAÚDE. CONSELHO NACIONAL DE SAÚDE. Comissão Organizadora da III CNSM. Relatório Final da III Conferência Nacional de Saúde Mental. Brasília, 11 a 15 de dezembro de 2001. Brasília: Conselho Nacional de Saúde/Ministério da Saúde, 2002, 213 p.

SMAS RJ. SECRETARIA MUNICIPAL DE ASSISTÊNCIA SOCIAL DO RIO DE JANEIRO. Resolução no 20, 27 de março de 2011. Cria e regulamenta o protocolo do Serviço Especializado em Abordagem Social, visando às ações de proteção social especial de média complexidade.

SZYMANSKI, H. Teorias e "Teorias" de famílias. In: CARVALHO, M. C. B. A Família Contemporânea em debate. 2. ed. São Paulo: Cortez, 1997.

TAUILE, J. R. Para (re)construir o Brasil Contemporâneo. Rio de Janeiro: Editora Contraponto, 2001.

TUMELERO, S. M. Intersetorialidade nas políticas públicas. Seminário Nacional Sociologia \& Política. Universidade Federal do Paraná - UFPR, 26 a 28 de setembro de 2011.

UNITED NATIONS OFFICE ON DRUGS AND CRIME (UNODC). Drogas: marco legal. Disponível em <http://www.unodc.org/lpobrazil/pt/drogas/marco-legal.html>. Acesso em 28 mar. 2015.

VALLIM, D. C. As políticas públicas municipais voltadas a enfrentamento de crack para crianças e adolescentes no Rio de Janeiro: uma regressão dos direitos humanos. $2^{0}$ International Sociological Association. Buenos Aires, 2012.

VASCONCELOS, E. M. Cenário econômico, social e psicossocial no Brasil recente, e a crescente difusão do crack: balanço e perspectivas de ação. O Social em questão, v. 28, n. 28. Revista do programa de pósgraduação do departamento de Serviço Social da PUC. Rio de Janeiro: PUC-Rio, 2012. p. 149 -186.

VESENTINI, J. W. Sociedade e Espaço - Geografia Geral e do Brasil. 26. ed., São Paulo: Ática, 1996.

WACQUANT, L. As Prisões da Miséria. Tradução: André Telles. Rio de Janeiro: Jorge Zahar, 2001.

Punir os pobres: a nova gestão da miséria nos Estado Unidos. Rio de Janeiro: Instituto Carioca de Criminologia, 2001.

WIKIPEDIA. Ditadura Militar no Brasil (1964-1985). Disponível em: <http://pt.wikipedia.org/wiki/Ditadura_militar_no_Brasil_\%2819641985\%29>. Acesso em 12 fev. 2015. 
WIKIPEDIA. Guarda Municipal do Rio de Janeiro. Disponível em: $<$ http://pt.wikipedia.org/wiki/Guarda_Municipal_do_Rio_de_Janeiro\#Opera .C3.A7.C3.A3o_choque_de_ordem>. Acesso em 03 set. 2014.

YAZBEK, M. C. Pobreza no Brasil contemporâneo e formas de seu enfrentamento. Revista Serviço Social e Sociedade, n. 110. São Paulo: Cortez, 2012. 